UNIVERSIDADE DE BRASÍLIA

Centro de Excelência em Turismo

\title{
REFERÊNCIAS DO BRASIL PRÉ-INDUSTRIAL ÚTEIS AO TURISMO EM ÁREAS NATURAIS E RURAIS
}

\section{Eduardo Rodrigues Nogueira da Gama}

Prof ${ }^{\mathrm{a}}$ Dra. Tânia Siqueira Montoro Orientadora

\begin{abstract}
Monografia apresentada ao
Centro de Excelência em Turismo da Universidade de Brasília como requisito parcial para a obtenção do certificado de Especialista em Ecoturismo
\end{abstract}

Brasília, DF, setembro de 2004 


$$
\begin{gathered}
\text { UNIVERSIDADE DE BRASÍLIA } \\
\text { Centro de Excelência em Turismo } \\
\text { Curso de Especialização em Ecoturismo }
\end{gathered}
$$

REFERÊNCIAS DO BRASIL PRÉ-INDUSTRIAL ÚTEIS AO TURISMO EM ÁREAS NATURAIS E RURAIS

Eduardo Rodrigues Nogueira da Gama

\author{
Banca Examinadora
}

Prof ${ }^{a}$ Dra. Tânia Siqueira Montoro Orientadora

Profa Dra. Maria Thereza Negrão de Mello Banca 
EDUARDO RODRIGUES NOGUEIRA DA GAMA

REFERÊNCIAS DO BRASIL PRÉ-INDUSTRIAL ÚTEIS AO TURISMO EM ÁREAS NATURAIS E RURAIS

Comissão Avaliadora

Professora Orientadora: Prof ${ }^{a}$ Dra. Tânia Siqueira Montoro

Banca: Prof ${ }^{a}$ Dra. Maria Thereza Negrão de Mello

Brasília, DF, 20 de setembro de 2004 
à minha Pipa. 
Agradeço aos meus pais e à minha esposa pelo apoio necessário para frequentar e concluir este curso. E agradeço particularmente à minha sócia Patrícia por permitir a inclusão de nosso trabalho de resgate do livro Tesouro das Famílias nesta monografia. 


\section{RESUMO}

A Monografia "REFERÊNCIAS DO BRASIL PRÉ-INDUSTRIAL ÚTEIS AO TURISMO EM ÁREAS NATURAIS E RURAIS" é um resgate de parte do livro Tesouro das Famílias, de Pierre Victor Renault, cuja última edição data de 1901. Foram selecionados em suas 1.952 receitas, técnicas, métodos e procedimentos que servem ao Ecoturismo e às suas exigências de sustentabilidade. Em seu primeiro capítulo, o trabalho busca situar o Ecoturismo no mercado de Turismo, suas conexões com o Turismo Cultural e com o Turismo Rural, e identificar o público alvo do Ecoturismo nos grupos Criativos Culturais e adeptos da Simplicidade Voluntária. O segundo capítulo apresenta Pierre Victor Renault, usando como fonte principal a carta a seu irmão Léon, escrita 45 anos após sua chegada ao Brasil. $O$ terceiro capítulo é dedicado à exposição do texto de Victor Renault, objeto deste trabalho.

Palavras-Chaves - Ecoturismo, Turismo Cultural, Turismo Rural, Tesouro da Famílias 


\begin{abstract}
The Monograph "REFERENCES OF THE PREINDUSTRIAL BRAZIL, USEFUL TO NATURE TOURISM AND RURAL TOURISM" is a retrieve from a piece of the book "Tesouro das Famílias", by Pierre Victor Renault, which last edition was in 1901. Several technics, methods and procedures helpful to Ecotourism and its requirements of sustenance were taken from its 1,952 recipes. On the first chapter, the work intends to place Ecotourism as a market segment, show its connections with Cultural Tourism and Rural Tourism, and identify its target market in Cultural Creative groups and followers of Voluntary Simplicity. The second chapter introduces Pierre Victor Renault using as main source the letter to his brother Léon, written 45 years after his arrival in Brazil. The third chapter is dedicated to Victor Renault's text, the subject of this work.
\end{abstract}

Key-words, Cultural Tourism, Rural Tourism, Tesouro da Famílias 


\section{Sumário}

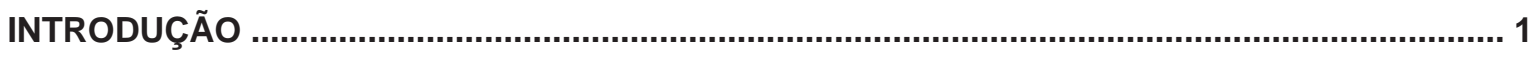

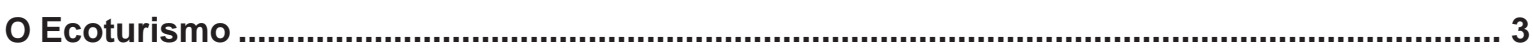

1.1 - O Ecoturismo como segmento de mercado.................................................................. 3

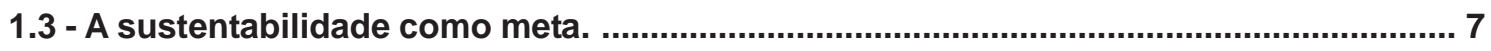

1.4 - Economia Circular e MDL - Mecanismo de Desenvolvimento Limpo. ............................ 7

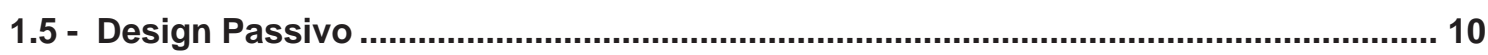

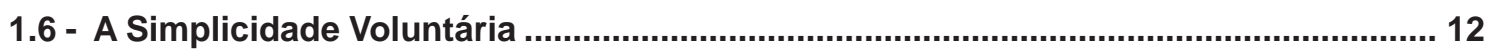

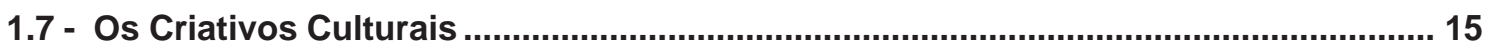

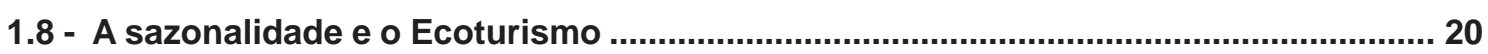

1.9 - As conexões do Turismo Rural com o Ecoturismo .................................................... 22

1.10 - As conexões do Turismo Cultural com o Ecoturismo …........................................... 27

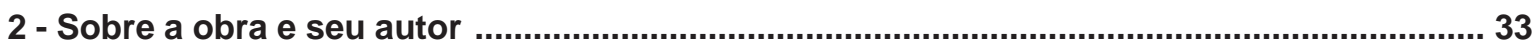

2.1 - Sobre o livro Tesouro das Famílias ....................................................................... 33

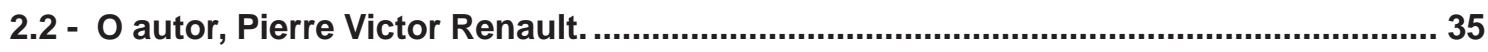

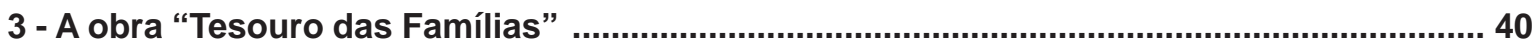

3.1 - Receitas, métodos e procedimentos do Tesouro das Famílias ................................. 40

3.2 - Comparação entre as versões original (Typographia Garnier Irmãos, 1901) e atualizada (Dagama Editora, inédito) ............................................................................ 41

3.3 - Tabelas de conversão e equivalência de pesos, medidas e temperatura.................... 42

3.3.1. - Tabela de conversão de temperatura ................................................................ 42

3.3.2- Capacidade - Equivalência ............................................................................... 43

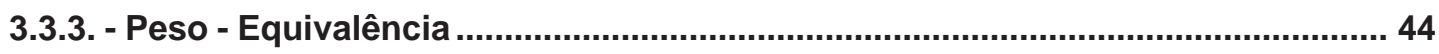

3.3.4 - Distância/comprimento - Equivalência ............................................................. 45

3.4 - AS RECEITAS, MÉTODOS, TÉCNICAS E PROCEDIMENTOS .......................................46

3.4.1. Receita para limpar e refrescar a água. ............................................................... 46

3.4.2. Método abreviado, fácil e seguro de clarificar o açúcar. ....................................46

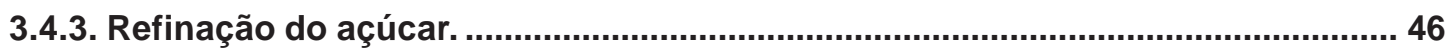

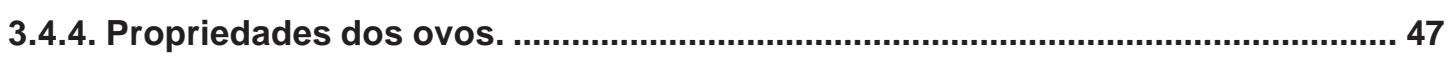

3.4.5. Meio de conservar ovos...................................................................................... 47

3.4.6. Ovos; método de conservá-los frescos por muito tempo. ................................. 47

3.4.7. Meio de conhecer ovos frescos. ..................................................................... 48

3.4.8. Outro modo de conhecer os ovos frescos. ......................................................... 48

3.4.9. Modo de impedir que o leite se altere. ............................................................. 48

3.4.10. Modo de conservar o leite por muito tempo.................................................... 48

3.4.11. Modo de conservar o leite em pó....................................................................... 48 
3.4.12. Modo de preparar a manteiga para conservá-la fresca por muitos anos. ........ 48

3.4.13. Depuração dos óleos e manteigas. ................................................................ 49

3.4.14. Peixe; processo para conservar fresco por muito tempo. .................................. 51

3.4.15. Meios de conservar e de salgar os peixes....................................................... 51

3.4.16. Modo de conservar carne fresca. .............................................................. 53

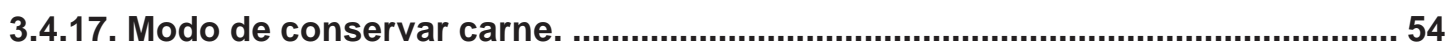

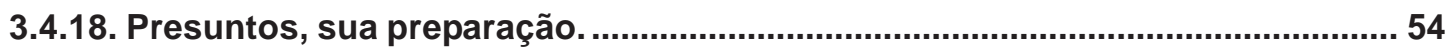

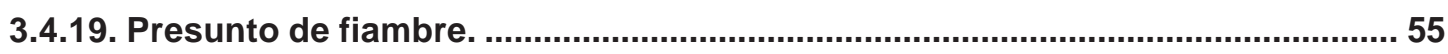

3.4.20. Outra preparação dos presuntos. ................................................................ 55

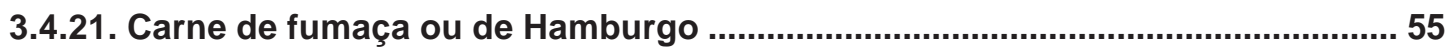

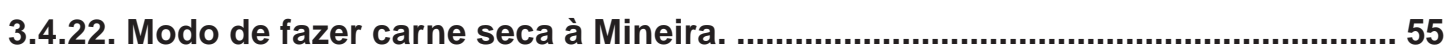

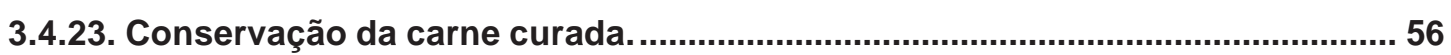

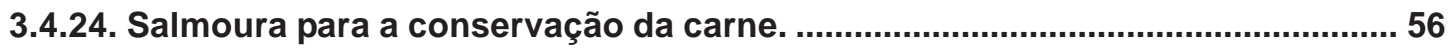

3.4.25. Conservação das carnes em estado fresco ou salgado................................... 56

3.4.26. Método de conservar os frutos sem alteração alguma por mais de um ano... 56

3.4.27. Para conservar os frutos de pevide em seu perfeito estado de madureza por mais de um ano............................................................................................... 57

3.4.28. Método de preparar os frutos para se transportarem.................................... 58

3.4.29. Conservação das frutas no estado de frescas por meio da guta-percha. ......... 59

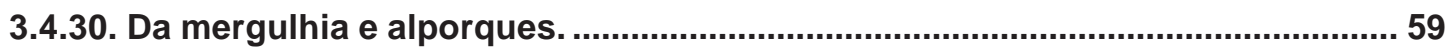

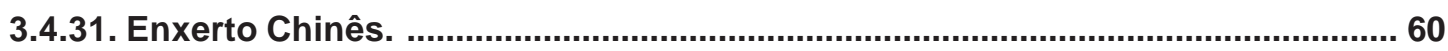

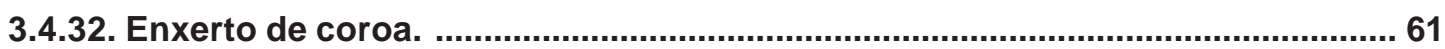

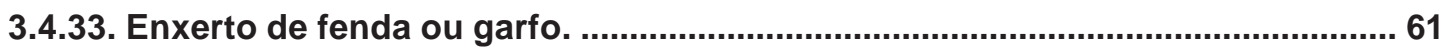

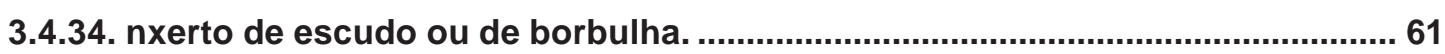

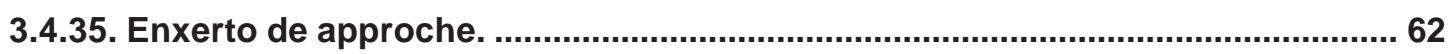

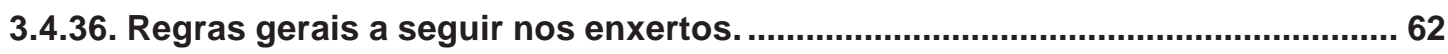

3.4.37. Reproduzir as árvores por meio de estacas empregando o colódio. ............... 62

3.4.38. Reprodução das plantas por meio do carbono. .............................................. 63

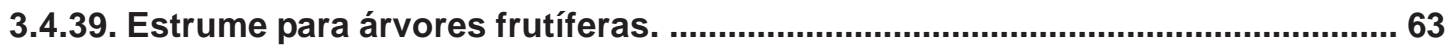

3.4.40. Observações importantes acerca da poda das árvores frutíferas. ...................63 63

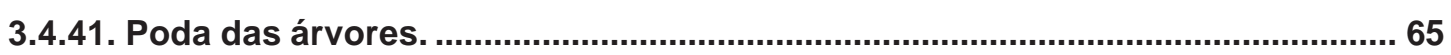

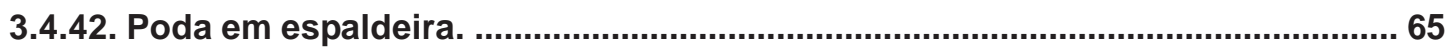

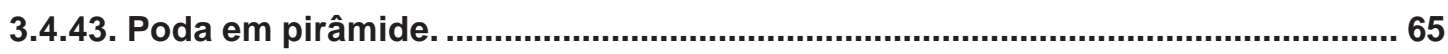

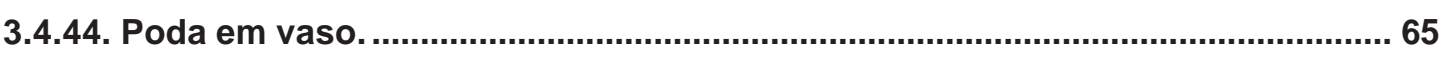

3.4.45. Fazer um mesmo pé dar flores diferentes. ......................................................6 66

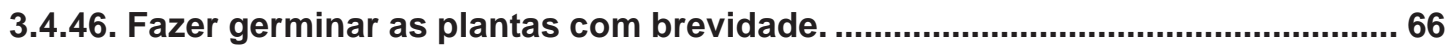

3.4.47. Enxertos de tomates sobre batatas. ...........................................................6 66

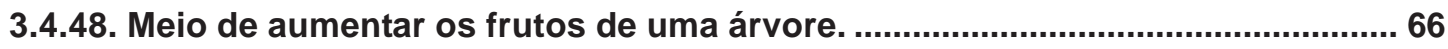

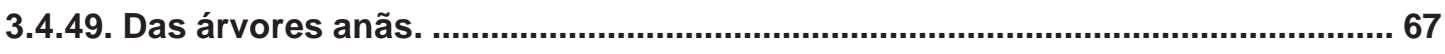

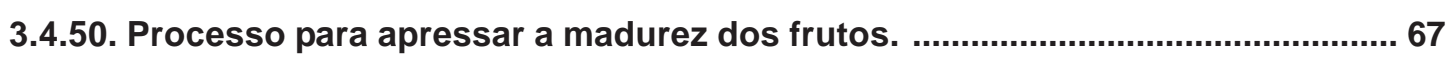




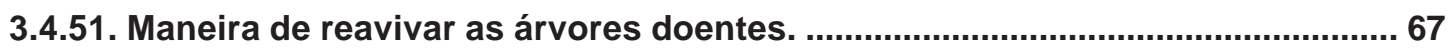

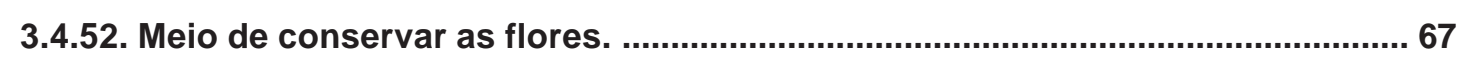

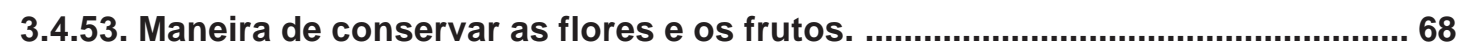

3.4.54. Modo de conservar flores frescas por muito tempo sem murchar. ................... 68

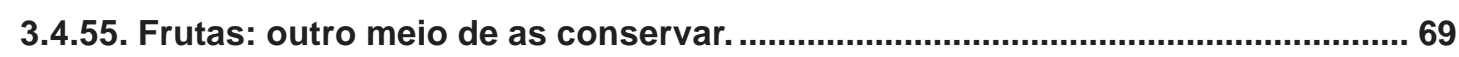

3.4.56. Processo para obter frutos de uma grossura extraordinária. ............................ 69

3.4.57. Processos para obter quaisquer qualidades de plantas de muita grossura. ... 69

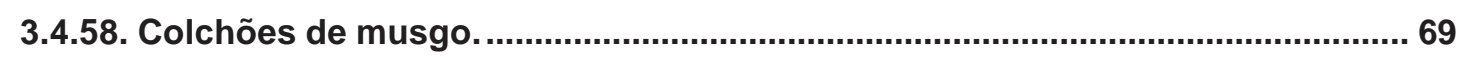

3.4.59. Modo de conhecer as mudanças de tempo pelos meteoros. ............................ 70

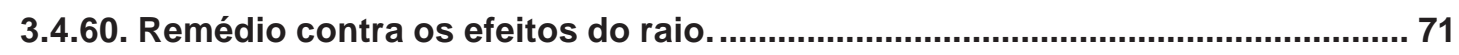

3.4.61. Desinfecção das matérias fecais. ............................................................... 71

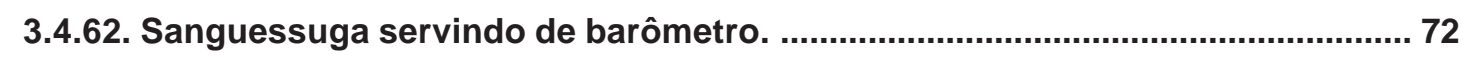

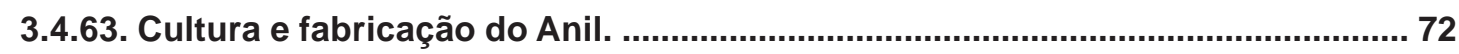

3.4.64. Cultura e preparação da Cochonilha. ............................................................... 72

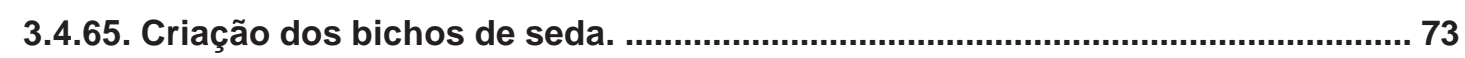

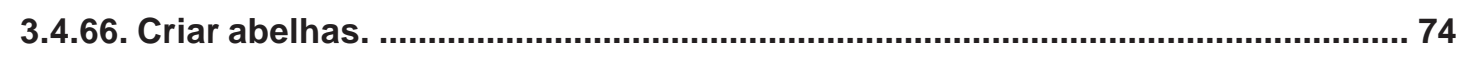

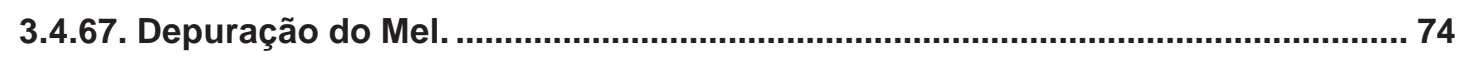

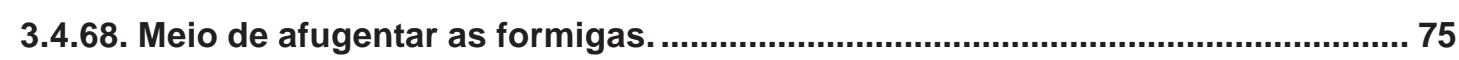

3.4.69. Meio de acabar com as formigas que não se pode perseguir em seus ninhos. 75

3.4.70. Meio de afugentar as formigas doceiras. ..................................................... 75

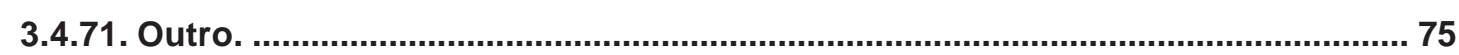

3.4.72. Meio de destruir os insetos nos quintais. ................................................. 76

3.4.73. Meio de preservar as árvores das formigas e de outros insetos nocivos. ...... 76

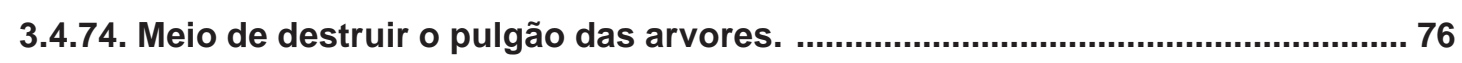

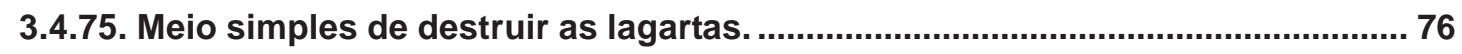

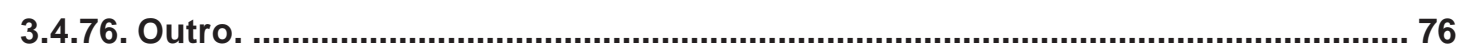

3.4.77. Contra o pulgão e o percevejo da terra............................................................ 76

3.4.78. Remédio contra as lesmas e os caracóis. ........................................................... 76

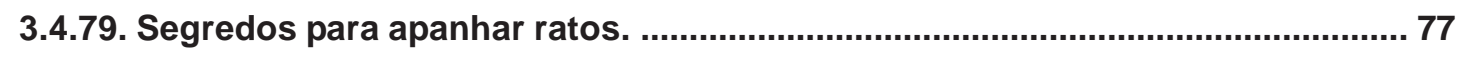

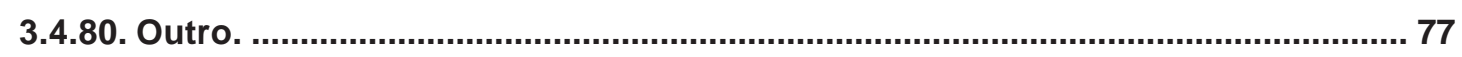

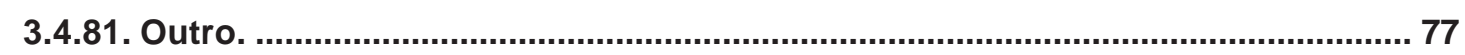

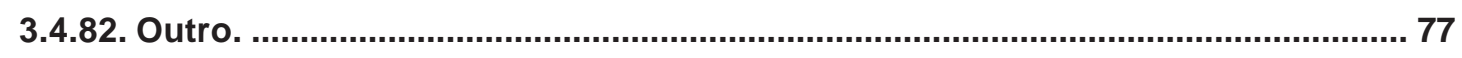

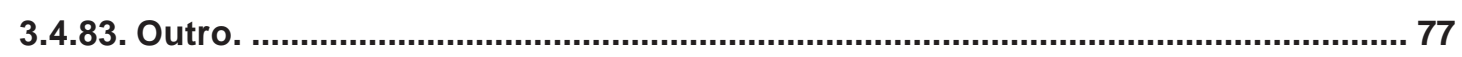

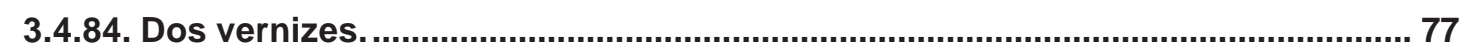

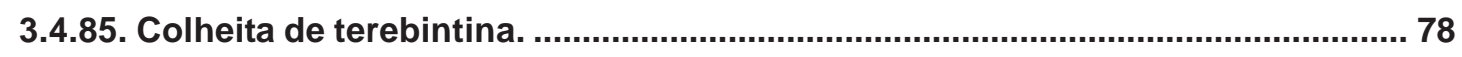

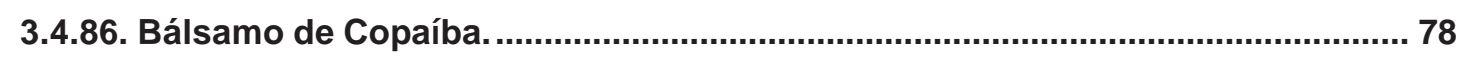

3.4.87. Das matérias sólidas que entram nas composições dos vernizes; sua escolha e

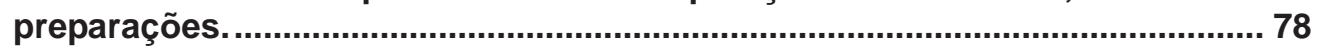

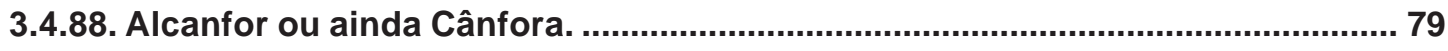

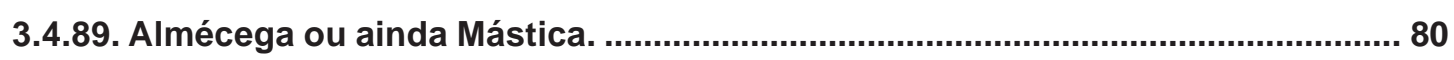


3.4.90. Goma resina Anima (em francês, Résine animée). ......................................... 80

3.4.91. Urucu (em francês, Roucou ou rocu). ............................................................ 80

3.4.92. Asfalto ou betume judaico (em francês, Asphalte, ou poix minérale). ............. 81

3.4.93. Benjoim, asa dulcis ou benzoe (em francês, Benjoim). ..................................... 81

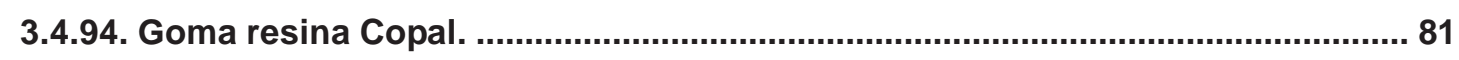

3.4.95. Caout-chouc, vulgarmente goma, ou resina elástica. .................................... 82

3.4.96. Colofônio (em francês, Colophane, galipot, arcançon, poix résine, e encens blanc). 83

3.4.97. Goma resina Elemi (em francês, Elemi). ........................................................ 83

3.4.98. Goma-resina Guta (em francês, Gomme-gutte). ............................................ 83

3.4.99. Goma-resina Laca (em francês, Laque). ........................................................... 84

3.4.100. Goma-resina Graxa, ou goma-verniz (em francês, Sandarac, ou verniz)....... 84

3.4.101. Sangue de drago (em francês sang dragon). ............................................... 85

3.4.102. Curcuma, terra merita, vulgarmente chamada gengibre amarela. ................... 85

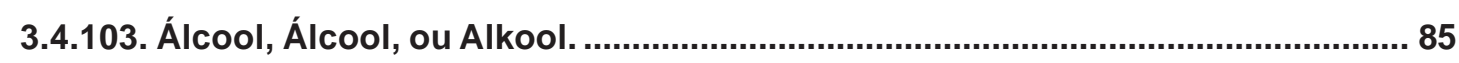

3.4.104. Álcool: modo de o obter bem retificado para diversas operações indicadas

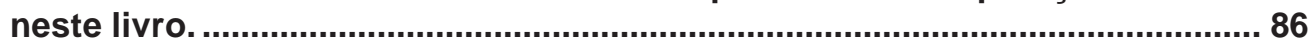

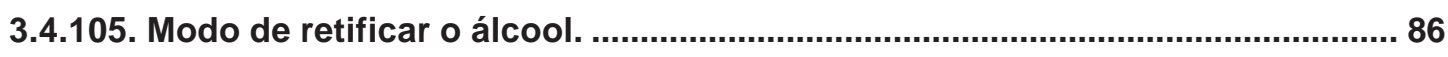

3.4.106. Modo de reforçar o álcool sem destilação.................................................... 86

3.4.107. Outro método de destilar o Álcool sem alambique. ...................................... 86

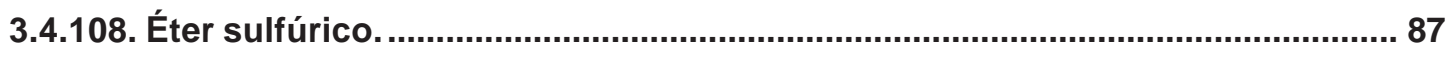

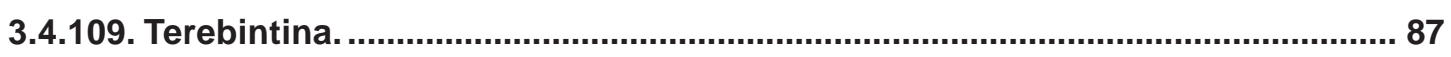

3.4.110. Óleo etéreo de terebintina, ou essência de terebintina (também se denomina essência, simplesmente). .................................................................................. 88

3.4.111. Óleo de nozes e de linhaça. ........................................................................ 88

3.4.112. Dos vernizes de álcool e de essências........................................................... 88

3.4.113. Verniz de copal por meio da cânfora e do óleo essencial de lavândula, destinado aos objetos elásticos, tais como as telas metálicas que substituem as vidraças nas janelas e nas portas dos navios, etc. ......................................................... 89

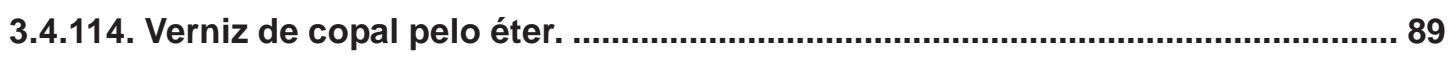

3.4.115. Verniz de copal feito com essência. .................................................................. 90

3.4.116. Verniz para utensílios metálicos e para o ferro. ............................................. 91

3.4.117. Dos Vernizes gordos, graxos, ou de charão. ................................................ 91

3.4.118. Dos vernizes graxos de óleo e copal, ou de alambre. .................................... 92

3.4.119. Verniz de óleo secante, ou graxo, ou seja com a copal, ou com o alambre... 92

3.4.120. Verniz inglês para douraduras, feito pelo óleo graxo secante e o alambre. .. 92

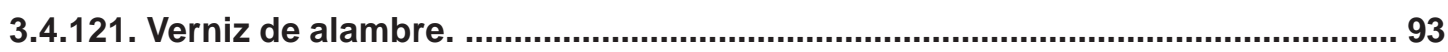

3.4.122. Verniz de alambre com álcool ..................................................................... 93

3.4.123. Verniz de caout-chouc para os tafetás encerados, algálias, aeróstatos, etc. 93

3.4.124. Verniz que imita escama. .......................................................................... 93

3.4.125. Verniz para tornar impermeáveis os panos e estofos. ..................................... 94

3.4.126. Tinta para conservar a madeira e o ferro. ...................................................... 94 
3.4.127. Método para preparar a estearina, segundo Chevreul. ................................... 94

3.4.128. Método para preparar a estearina (segundo Heard). ..................................... 96

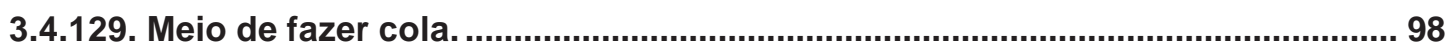

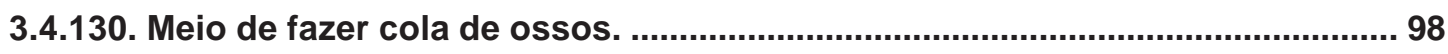

3.4.131. Massa para fazer fósforos franceses. .......................................................... 99

3.4.132. Lamparina química que dá claridade suficiente para consultar de noite um

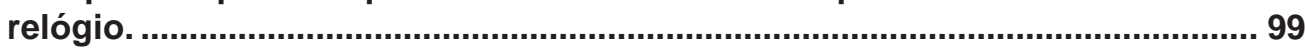

3.4.133. Meio de fazer durar o azeite nos lampiões. .................................................... 99

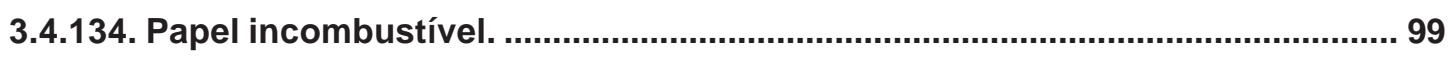

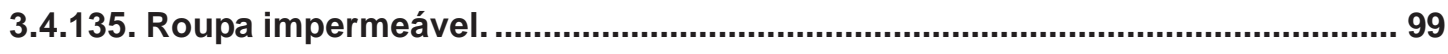

3.4.136. Meio de tornar a roupa incombustível........................................................ 100

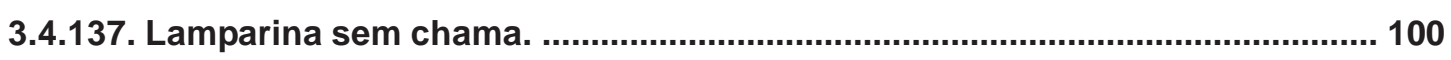

3.4.138. Processo de vulcanizar o caout-chouc e a guta-percha. ............................... 100

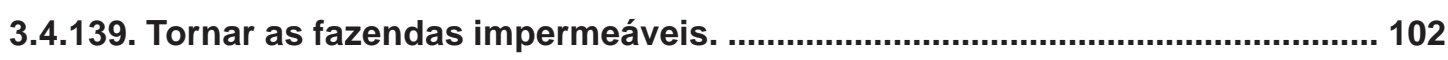

3.4.140. Processo para fazer o papel de palha......................................................... 102

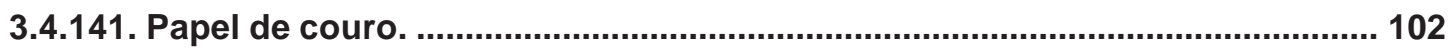

3.4.142. Papelão duro como pedra......................................................................... 103

3.4.143. Meio de tornar o calçado impermeável. ...................................................... 103

3.4.144. Cimento que se assemelha ao Cimento Romano. .......................................... 103

3.4.145. Betume submarino. ....................................................................................... 103

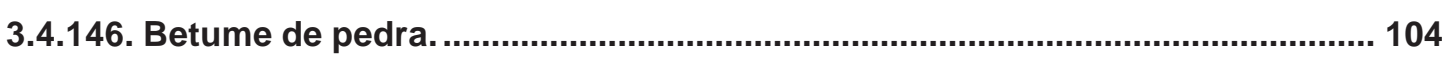

3.4.147. Betume para segurar grades de ferro sobre pedras. .................................... 104

3.4.148. Cimento para fixar o metal sobre o vidro ou madeira. .................................. 104

3.4.149. Betume para vedar o coamento dos líquidos dos tonéis, barris, ou pipas. 104

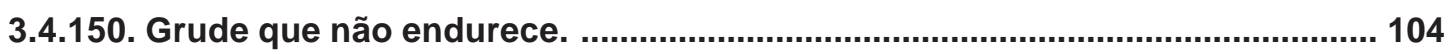

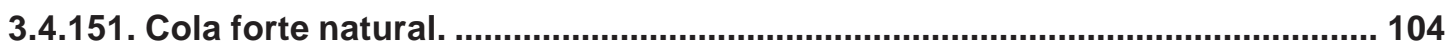

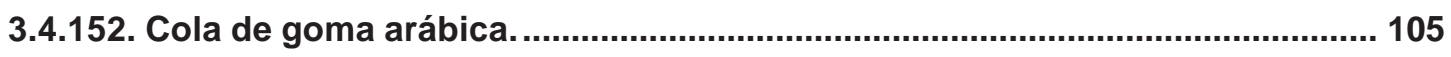

3.4.153. Cola ou grude de arroz. ............................................................................. 105

3.4.154. Meio de tornar panelas e potes de barro e de pedras mais resistentes. ...... 105

3.4.155. Modo de tornar o calçado impermeável á água. ........................................... 105

3.4.156. Nitreiras artificiais. ................................................................................ 105

3.4.157. Meio de conservar a madeira de construção. …............................................ 106

3.4.158. Madeira; receita para torná-la incombustível. .............................................. 106

3.4.159. Modo de dar rijeza à madeira. .................................................................... 106

3.4.160. Meio de dar duração à madeira. .......................................................................... 107

3.4.161. Meio de empregar a madeira verde sem empenar. ...................................... 107

3.4.162. Processo para tornar a madeira indestrutível. ............................................ 107

3.4.163. Meio de fazer cal virgem em pequena porção. ............................................... 107

3.4.164. Cimento impermeável á água. ......................................................................... 107

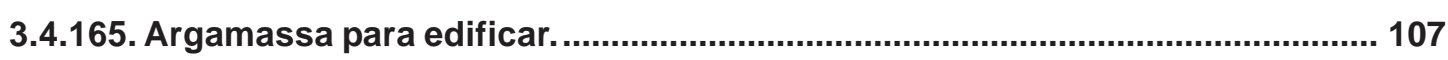


3.4.166. Modo de cobrir casas com papelão.

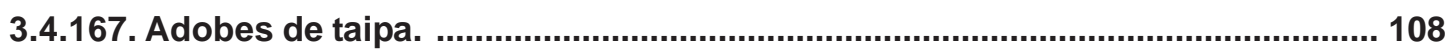

3.4.168. Método de conservar os aposentos sem umidade. ....................................... 109

3.4.169. Refrescar os aposentos durante os grandes calores.................................. 109

3.4.170. Meio de curtir os couros. ................................................................................. 109

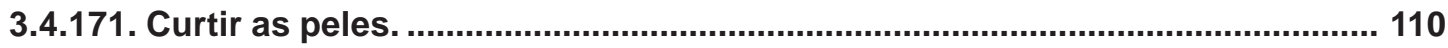

3.4.172. Solas impermeáveis. .............................................................................................111

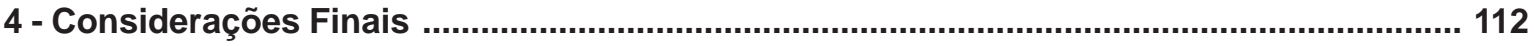

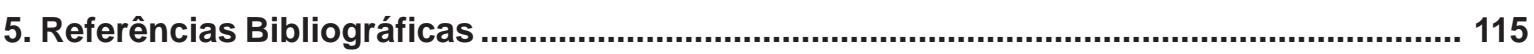




\section{INTRODUÇÃO}

O Ecoturismo, como todo conceito novo, surgiu para separar situações que, apesar de semelhantes, não são idênticas. As diversas formas de turismo em áreas naturais e rurais confundem-se na literatura e no meio acadêmico e essa confusão propaga-se até o mercado, gerando ofertas que, mesmo não sendo mal-intencionadas, são falaciosas e contrariam as expectativas dos consumidores exigentes. Empregar o termo Ecoturismo garante o charme para todos os empreendimentos realizados em áreas não urbanas.

O Ecoturismo traz em si um arcabouço conceitual com critérios bastante claros, e dispõe de entidades certificadoras internacionais para que o uso do termo não se banalize. A "Declaração de Ecoturismo de Quebec", conhecida como Carta de Quebec, documento resultante de evento realizado em 2002, com mais de 3 mil representantes de governos, iniciativa privada, universidades, ONGs, comunidades indígenas e tradicionais estipula as ações que devem ser realizadas em todos os níveis para a implementação de projetos ecoturísticos.

Este trabalho procurará, em seu primeiro capítulo, situar o Ecoturismo no mercado do Turismo, baseado em seus conceitos, e identificar seu público alvo de acordo com as suas predileções. Estabelecer as conexões do Ecoturismo com o Turismo Rural e com o Turismo Cultural, delimitando-os segundo a carga de influência dos ambientes urbanos sofrida por estes.

No segundo capítulo, será apresentado o autor do livro Tesouro das Famílias, Pierre Victor Renault, tendo como fonte principal sua carta a seu irmão Léon, escrita 45 anos após sua partida do seu país de origem, a França. Na carta, de forte conteúdo emocional, Renault narra sua história de desbravador, suas expedições por territórios habitados por índios botocudos, altamente refratários à presença de invasores em suas terras, e seu respeito por estas etnias, praticando o não-revide às agressões, comportamento adotado atualmente pelo indigenismo brasileiro. Conhecer a história de Victor Renault e sua capacidade de sobrevivência em um mundo desconhecido e inóspito, reforça a credibilidade que podemos atribuir ao empirismo de seus métodos. Suas receitas, entretanto, não são resultado apenas do empirismo, sendo fruto de pesquisa de um engenheiro de minas, médico, professor de francês, inglês, química, física, matemática e alemão e a quem se atribui a divulgação do sistema métrico no Brasil.

No terceiro capítulo, serão divulgadas técnicas, métodos, receitas e procedimentos praticados no Brasil do século XIX, extraídas do livro Tesouro das Famílias, que sirvam de subsídios ao Ecoturismo para a restauração e recuperação do patrimônio cultural; sirvam ao uso por populações carentes, por serem aplicações 
que demandam investimentos modestos, de baixo impacto ambiental e que dispensam máquinas; e que sirvam também a empreendedores em Ecoturismo que pretendam que seus projetos utilizem técnicas genuinamente artesanais e que remontem as condições em que se vivia no Brasil nos tempos pré-industriais. As dificuldades enfrentadas por aqueles que habitam áreas não atendidas pelas facilidades urbanas, como a conservação dos alimentos sem refrigeração ou materiais adequados para construção, pouco diferem das dificuldades que tinham as populações do século XIX. Esta monografia também pretende ser útil àqueles que aventuramse em expedições, com propósitos turísticos ou não, onde a conservação e transporte de alimentos é fator crítico.

O texto utilizado é a atualização do livro Tesouro das Famílias, realizada pelo autor desta monografia e por Patrícia R. C. Nogueira da Gama. Por ser um texto inédito e indisponível para consulta em outras fontes, será transcrito em sua íntegra. A escolha das receitas que constam neste trabalho seguiu, principalmente, a atenção à capacidade das populações de baixa renda de relacionarem-se com a natureza circundante sem a necessidade de recorrência a recursos identificados com as tecnologias inerentes aos ambientes urbanos.

As imagens que ilustram este têm sua própria narrativa, e condizem com os conceitos que se procura estabelecer para o Ecoturismo.

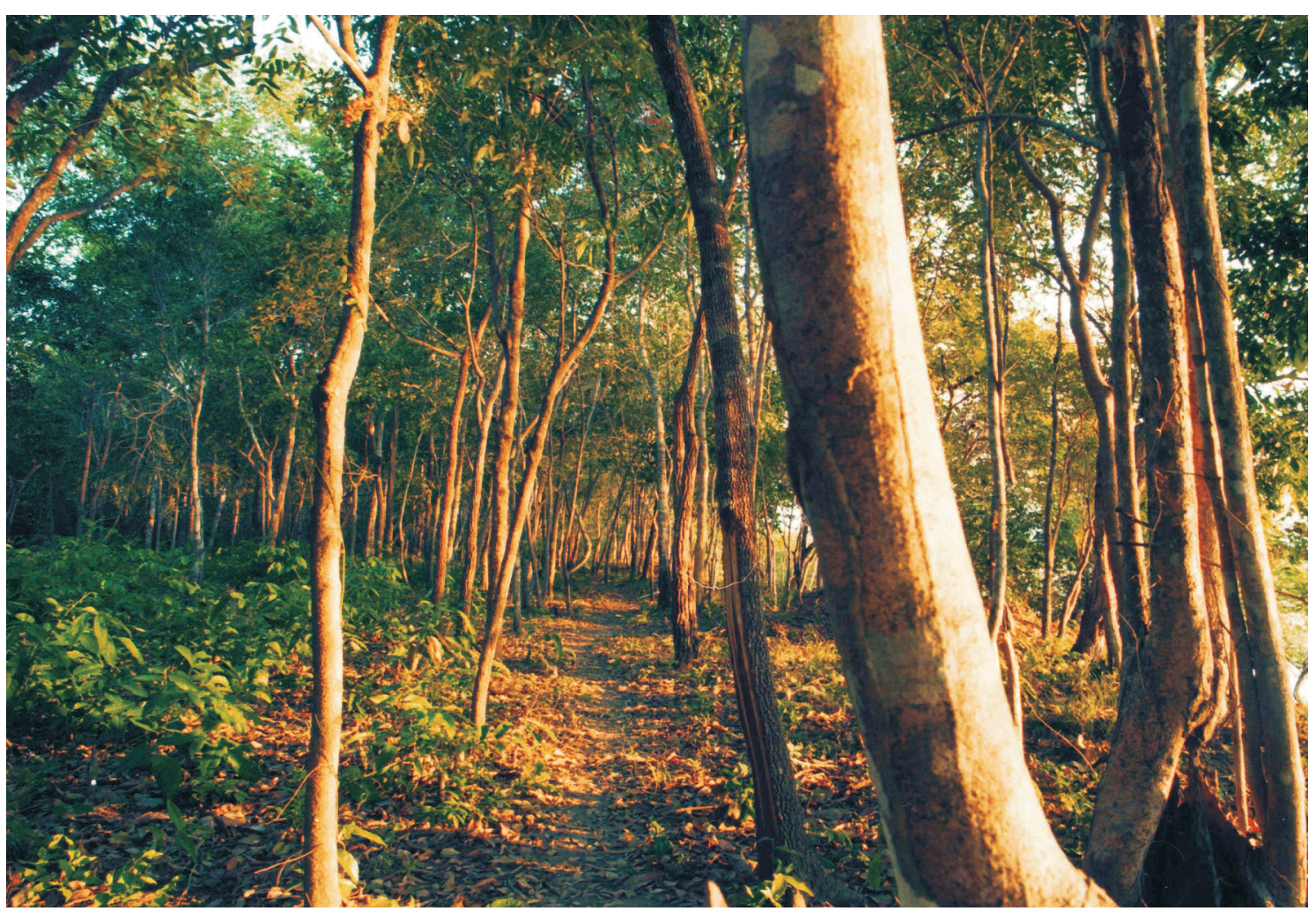

Trilha Ecológica - Rio Manso-MT 


\section{O Ecoturismo}

\section{1 - O Ecoturismo como segmento de mercado.}

Segundo a publicação Ecotourism: Principles, Pratices \& Policies for Sustainability (WOOD, 2002, pg. 10), são os seguintes os componentes do Ecoturismo:

- $\quad$ Contributes to conservation of biodiversity

- $\quad$ Sustains the well being of local people.

- Includes an interpretation/learning experience.

- Involves responsible action on the part of tourists and the tourism industry.

- Is delivered primarily to small groups by small-scale businesses.

- Requires lowest possible consumption of non-renewable resources.

- $\quad$ Stresses Local participation, ownership and business opportunities, particularly for rural people. ${ }^{1}$

Wood (2002)

Como segmento do mercado de turismo, o Ecoturismo, assim como o Turismo de Aventura, é classificado como uma sub-atividade do Turismo em Áreas Naturais e tem fortes conexões com o Turismo Cultural e com o Turismo Rural. Esta sistematização, apesar de ser a adotada pela Associação Internacional de Ecoturismo (TIES) e pelo Programa das Nações Unidas para o Meio Ambiente (PNUMA), não é consensual,

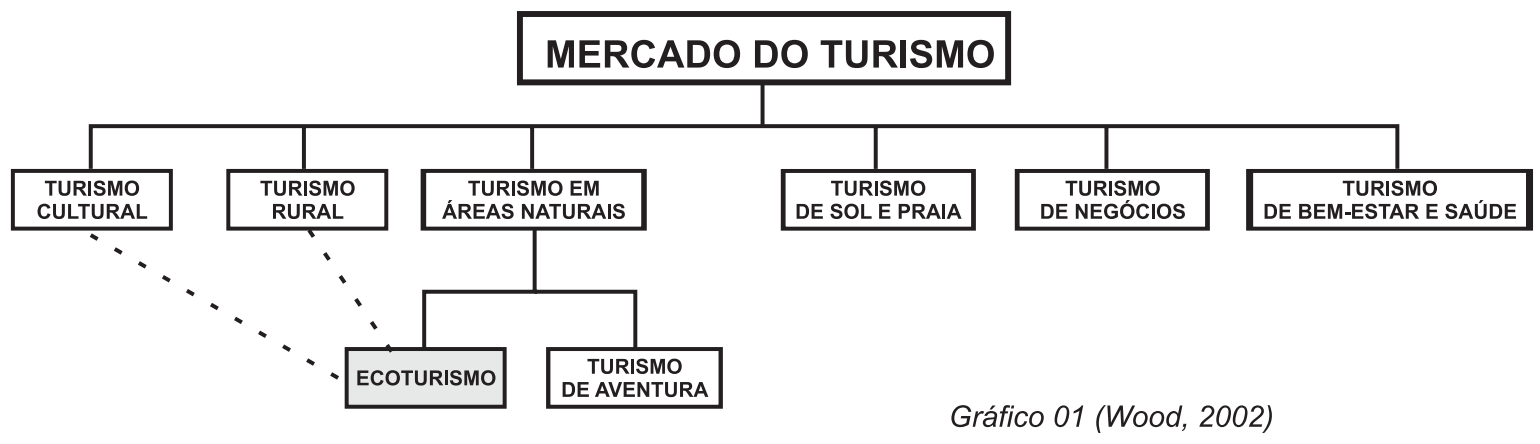

- $\quad$ Contribui para a conservação da biodiversidade.

- $\quad$ Favorece o bem-estar das populações locais.

- Inclui uma experiência de interpretação/aprendizado.

- $\quad$ Envolve ações responsáveis por parte do turista e dos demais envolvidos na atividade turística.

- $\quad$ É oferecido para grupos pequenos por empreendimentos de pequena escala.

- Requer o menor consumo possível de recursos não-renováveis.

- $\quad$ Encoraja a participação local, a oportunidade de propriedade e negócios, particularmente para as populações rurais. 
conforme veremos na seção que analisa as conexões do Ecoturismo com o Turismo Rural. A conveniência de usá-la também será discutida na mesma seção.

Como atividade geradora de lucros aos empreendedores, o Ecoturismo deve ser visto com cautela, observando seus conceitos à luz dos princípios da microeconomia. De acordo com estes princípios, as empresas maximizam seus lucros quando a receita marginal (variação na receita total decorrente da venda de uma unidade adicional) é maior do que o custo marginal (quantia gasta para se produzir mais uma unidade) (Mankiw, 2001, pg. 297). Gregory Mankiw ilustra esta situação com o seguinte exemplo:

"Suponha que o custo para a empresa aérea de uma viagem em um avião de 200 lugares seja de US\$100 mil. Neste caso, o custo médio de cada assento é de US\$100.000/200, ou seja, US\$500. Poderia se concluir que a empresa nunca deveria vender uma passagem por menos de US\$500.

Contudo, a empresa pode aumentar seus lucros pensando na margem. Suponha que o avião vai decolar com dez assentos vazios. Um passageiro "standby" está no portão de embarque querendo pagar US $\$ 300$ pela passagem. A empresa deveria vender a passagem? Claro que sim. Se o avião tem assentos vazios, o custo de mais um passageiro é ínfimo. Embora o custo médio de transportar um passageiro seja de US\$ 500, o custo marginal é apenas o amendoim e o refrigerante que o passageiro extra irá consumir. Uma vez que o passageiro "standby" paga mais que o custo marginal, a venda dessa passagem é lucrativa".

(Mankiw, 2001,pg 7)

Assim se comportam as empresas em mercados competitivos. Esta lógica não pode ser aplicada ao Ecoturismo, pois esbarra em seu próprio conceito que, como se viu anteriormente, tem como um dos princípios a dedicação aos pequenos grupos e restringe a aceitação de novos clientes de acordo com a capacidade de carga do ambiente. Desta forma, a função precípua dos empreendimentos ecoturísticos não pode ser a geração de lucros. O Ecoturismo presta-se, com máxima eficiência, como dirimente de conflitos sociais em áreas naturais e rurais, como instrumento de empoderamento de populações locais e como opção às atividades degradantes do meio-ambiente.

A degeneração conceitual de projetos ecoturísticos é um risco permanente. Conceitos novos surgem para separar os semelhantes, e assim ocorre com o Ecoturismo, ao ser entendido como uma sub-atividade do Turismo em Áreas Naturais e separar-se do Turismo de Aventura. Como visto, guarda-se as conexões do Ecoturismo com o Turismo Rural e o Turismo Cultural, mas sem confundi-los. Classificar todas as formas de Turismo em Áreas Naturais como Ecoturismo é incidir no que se convencionou chamar de greenwashing, definição que se materializa na 
proliferação indiscernível de Ecolodges sem a observância das características essenciais do conceito de Ecoturismo.

Consoante Megan Apler Wood (WOOD, 2002, pg 27), o termo Ecolodge surgiu formalmente no mercado no "Primeiro Fórum Internacional de Ecolodge e Seminário de Campo", ocorrido em 1994, em Maho Bay Camps, nas Ilhas Virgens Americanas. O primeiro livro a oferecer uma definição internacional para Ecolodge foi "International Ecolodge Guidelines" (Mehta, Hitesh; Baez, Ana; O'Loughlin, Paul, 1995), que Wood descreve resumidamente da seguinte forma:

- $\quad$ "It conserves the surrounding environment, both natural and cultural.

- It has minimal impact on the natural surroundings during construction.

- It fits into its specific physical and cultural contexts through careful attention to form, landscaping and color, as well as the use of localized architecture.

- It uses alternative, sustainable means of water acquisition and reduces water consumption.

- It provides careful handling and disposal of solid waste and sewage.

- It meets its energy needs through passive design and combines these with their modern counterparts for greater sustainability.

- It endeavors to work together with the local community.

- It offers interpretative programs to educate both its employees and tourists about the surrounding natural and cultural environments.

- It contributes to sustalnable local development through research programs". ${ }^{2}$

(Wood, 2002, pg 28)

O Ecolodge é, portanto, não só a estrutura física que cumpre as normas citadas, mas também a relação que esta estrutura tem com o ambiente circundante. É esta conjugação que habilita os projetos à denominação de Ecoturismo. Seu uso indiscriminado por atividades que nada têm de ecológicas ou sustentáveis é nocivo

- Conserva os ambientes natural e cultural circundantes.

- $\quad$ Causa impactos mínimos no ambiente natural circundante durante a construção.

- $\quad$ Ajusta-se aos contextos físicos e culturais locais, quanto a forma, paisagismo, arquitetura e cores.

- Usa meios alternativos e sustentáveis de captação de água que reduzam seu consumo.

- Apresenta manejo cuidadoso do lixo e dejetos.

- Utiliza o Design Passivo para a aquisição da energia necessária objetivando maior sustentabilidade.

- Empenha-se em trabalhar com a comunidade local.

- Oferece programas interpretativos para educar turistas e empregados sobre os ambientes natural e cultural circundantes.

- $\quad$ Contribui para o desenvolvimento sustentável local com programas de aporte de recursos. 
ao negócio turístico em geral, no tocante à importância dada à veracidade das informações na oferta turística.

Uma das características pertinentes ao Ecoturismo é o uso sustentável dos recursos naturais. Segundo o Dicionário Aurélio, "sustentável" tem dois significados: o primeiro é "que se pode sustentar", e o segundo é "capaz de se manter mais ou menos constante, por longo período". O primeiro conceito, quando aplicado a um sistema natural, sugere interferência externa, e o segundo, aplicado ao mesmo sistema, sugere a capacidade de auto-equilíbrio dos sistemas vivos e, portanto, dinâmicos. Fritjof Capra explica que:

"Num ecossistema, por exemplo, cada espécie tem potencial para experimentar um crescimento exponencial de sua população, mas essa tendência é mantida sob contenção graças a várias interações equilibradoras que operam dentro do sistema. Crescimentos exponenciais só aparecerão quando o ecossistema for seriamente perturbado. Então, algumas espécies se converterão em ervas daninhas, alguns animais se tornarão pestes e outras espécies serão exterminadas, e dessa maneira todo o sistema será ameaçado" (Capra, 1996, pg. 65)

Assim, um ecossistema tem seu próprio mecanismo de correção, definido como laços de realimentação, que podem ser positivos, quando a realimentação for no sentido da ação em curso, e negativo quando a realimentação for no sentido contrário desta ação. A ação reprodutiva de uma espécie, por exemplo, sofre uma realimentação negativa quando seu alimento se torna escasso. (Capra, 1996, pg. 62)

Em um sistema natural com a interferência humana, há a necessidade de constantes avaliações das variáveis do sistema, como a qualidade da água e a do ar, para que ações degradadoras sejam corrigidas. $O$ que nos remete a primeira definição do Aurélio para sustentável, "o que se pode sustentar". É imprescindível, portanto, para se alcançar a sustentabilidade com a interferência humana, o pleno entendimento dos processos naturais, e a clara diferenciação entre a exploração de recursos esgotáveis e renováveis Esta exploração deve considerar os bens e serviços ambientais não só como matérias primas, mas também como sumidouro dos dejetos gerados no consumo.

A idéia de sustentabilidade, entretanto, apesar de ser emanada dos sistemas naturais, é aplicada também à capacidade de qualquer sistema de manter-se gerando seus próprios recursos. Desta forma, toda atividade humana, para não ter suas fontes esgotadas, deve ser sustentável. 


\section{3 - A sustentabilidade como meta.}

A consagrada definição elaborada pela Comissão Mundial sobre o Meio Ambiente, conhecida como Comissão Brundtland é a de que "o desenvolvimento sustentável é um processo de transformação no qual a exploração dos recursos, a direção dos investimentos, a orientação do desenvolvimento tecnológico e a mudança institucional se harmonizam e reforçam o potencial presente e futuro, a fim de atender às necessidades e aspirações futuras...é aquele que atende às necessidades do presente sem comprometer a possibilidade de as gerações futuras atenderem as suas próprias necessidades". (Relatório Brundland, 1987)

Esta definição alcança ações nas esferas públicas e privadas, individuais e coletivas. Traz também o componente intergeracional como garantia de perpetuação dos recursos através do tempo. Vale notar, no entanto, que ao estabelecer o atendimento às necessidades presentes, subentende a distribuição imediata dos benefícios ambientais. Em projetos de Ecoturismo, esta distribuição é realizada com a participação das comunidades locais em todas os níveis e etapas do projeto. Viabilizar a permanência dos benefícios financeiros e sociais entre as comunidades anfitriãs deve ser um dos objetivos orientadores das ações em projetos ecoturísticos. Também é de responsabilidade dos planejadores e empreendedores providenciar a sensibilização dos atores envolvidos nos projetos ecoturísticos para as questões ambientais. Como dito acima, a diferenciação entre recursos esgotáveis e renováveis e o entendimento de que o ambiente é a fonte dos recursos mas também o destino final dos dejetos gerados pelo consumo são conceitos-chave para a sustentabilidade, e devem ser os balizadores da educação ambiental.

É crucial para a sustentabilidade o entendimento de que o meio ambiente não é parte do sistema econômico e, sim, exatamente o inverso, a economia é um dos elementos do sistema ambiental. A Economia Circular é um conceito novo que encampa esta idéia, como se verá a seguir.

\section{4 - Economia Circular e MDL - Mecanismo de Desenvolvimento Limpo.}

A Economia Circular trata a sustentabilidade dos recursos renováveis de acordo com a sua taxa de extração equacionada com a sua taxa de reposição. Caso a extração seja maior que a reposição, o recurso se extinguirá. Radoslav Barzev define assim a sustentabilidade dos recursos esgotáveis e os custos sociais e ambientais da exploração dos recursos renováveis e esgotáveis:

"La sostenibilidad en el uso de los recursos no renovables depende principalmente de la velocidad de extracción. O sea, cuanto más rápido se extrae, más rápido se extingue, pues estos recursos no se pueden reproducir. La sostenibilidad depende, por lo tanto, de un nivel tecnológico que permita una mayor eficiencia en 
el aprovechamiento del recurso y un ritmo más lento de su extracción.

Por otro lado, el uso de los recursos naturales no genera únicamente beneficios. Desde el momento de su extracción, durante su transformación y en el consumo mismo se generan flujos permanentes de desechos que impactan negativamente el ecosistema, o sea el medio ambiente donde se generan los recursos naturales. Esto reduce la capacidad de regeneración de los recursos mismos.

Parte de la contaminación generada es absorta y reciclada de manera natural por el ecosistema. Si la contaminación es mayor que la capacidad de carga del ecosistema $A$, este se satura y su capacidad de producir bienes y servicios ambientales se reduce. Por tanto, el uso de los bienes y servicios ambientales genera beneficios para la sociedad, pero la emisión de desechos genera impactos negativos, que se traducen en costos. El uso sostenible de los recursos se logra cuando los beneficios económicos son mayores que los costos de producción sumados a los costos ambientales generados por la contaminación.." ${ }^{3}$

(Barzev, 2002, pg 13)

A Economia Circular estabelece valor para os bens e serviços ambientais. Diferentemente da Economia de Mercado, a Economia Circular enxerga valor não só nos bens ambientais, mas também nos serviços ambientais. Assim, uma floresta tem o seu valor como madeira em potencial, um bem ambiental, mas também pode ser valorada pela sua capacidade de produzir oxigênio e absorver $\mathrm{CO} 2$, um serviço ambiental.

Estes princípios encontram-se no MDL - Mecanismo de Desenvolvimento Limpo, criado pelo artigo 12 do protocolo de Kioto, cujo objetivo é o financiamento do desenvolvimento sustentável nos países não incluídos no anexo 1 do protocolo (tabela 01), pelos países que constam neste anexo.

"A sustentabilidade dos recursos esgotáveis depende principalmente da velocidade de extração. Ou seja, quanto mais rápido se extrai, mais rápido se extingue. A sustentabilidade depende, portanto, de um nível tecnológico que permita uma maior eficiência no aproveitamento do recurso e um ritmo mais lento de sua extração.

Por outro lado, os recursos naturais não geram somente benefícios. Desde o momento da extração, durante sua transformação e no consumo do mesmo se geram fluxos permanentes de dejetos que impactam negativamente o sistema, ou seja, o meio ambiente donde se geram os recursos naturais. Isto reduz a capacidade de regeneração dos mesmos recursos.

Parte da contaminação gerada é absorvida e reciclada de maneira natural pelo ecossistema. Se a contaminação é maior que a capacidade de carga do ecossistema, este se satura e sua capacidade de produzir bens e serviços ambientais se reduz. Portanto, o uso de bens e serviços ambientais geram benefícios para a sociedade, mas a emissão de dejetos geram impactos negativos que se traduzem em custos. O uso sustentável dos recursos acontece quando os benefícios econômicos são maiores que os custos de produção somados aos custos ambientais gerados pela contaminação." 


\section{Relatório da Conferência das Partes em sua Terceira Sessão}

Tabela: Total das emissões de dióxido de carbono das Partes do Anexo I em 1990, para os fins do Artigo 25 do Protocolo de Quioto

\begin{tabular}{|c|c|c|}
\hline Parte & ssões (Gg) & Porcentagem \\
\hline Alemanha & 1.012 .443 & 7,4 \\
\hline Austrália & 288.965 & 2,1 \\
\hline Austria & 59.200 & 0,4 \\
\hline Bélgica & 113.405 & 0,8 \\
\hline Bulgária & 82.990 & 0,6 \\
\hline Canadá & 457.441 & 3,3 \\
\hline Dinamarca & 52.100 & 0,4 \\
\hline Eslováquia & 58.278 & 0,4 \\
\hline Espanha & 260.654 & 1,9 \\
\hline Estados Unidos da América & 4.957 .022 & 36.1 \\
\hline Estônia & 37.797 & 0,3 \\
\hline Federação Russa & 2.388 .720 & 17,4 \\
\hline Finlândia & 53.900 & 0.4 \\
\hline França & 366.536 & 2,7 \\
\hline Grécia & 82.100 & 0.6 \\
\hline Hungria & 71.673 & 0,5 \\
\hline Irlanda & 30.719 & 0,2 \\
\hline Islândia & 2.172 & 0,0 \\
\hline Itália & 428.941 & 3,1 \\
\hline Japão & 1.173 .360 & 8,5 \\
\hline Letônia & 22.976 & 0,2 \\
\hline Lechtenstein & 208 & 0,0 \\
\hline Luxemburgo & 11.343 & 0,1 \\
\hline Mônaco & 71 & 0 \\
\hline Noruega & 35.533 & 0, \\
\hline Nova Żelàndia & 25.530 & 0,2 \\
\hline Paises Baixos & 167.600 & 1,2 \\
\hline Polónia & 414.930 & \\
\hline Portugual & 42.148 & 0 \\
\hline Reino Unido da Grã-Bretanha e Irlanda do Norte & 584.078 & 4 \\
\hline República Checa & 169.514 & \\
\hline Romênia & 171.103 & 1,2 \\
\hline Suécia & 61.256 & 0 \\
\hline Suiça & 43.600 & 0,3 \\
\hline Total & 13.728 .306 & 100,0 \\
\hline
\end{tabular}

\footnotetext{
* Dados baseados em informaçóes recebidas das 34 Partes do Anexo I que submeteram suas primeiras comunicacós nacionals em 11 de dezembro de 1997 ou antes dessa data, compiladas pelo Secretariado em wários documentos (A/AC 237/81; FCCCFP/1996/12/Add 2 e FCCC/5B/1997) 6). Algumas das com unicaç̋es continham dados sobre as emissöes de $\mathrm{CO} 2$ por fontes e remoçes por sumidouros resultantes de mudança no uso da terra e florestas, porém esses dados nä́ foram incluidos porque as informacôes foram relatadas de diferentes modos.
}

Tabela 1 - Frangetto \& Gazani, 2002, pg 392

Em essência, o MDL estabelece um mercado que troca a emissão de CO2 dos países com alto grau de industrialização pela capacidade de absorção de $\mathrm{CO} 2$ das florestas dos países menos industrializados. (Frangetto \& Gazani, 2002). A forma que se estipula valores monetários e a fundamentação jurídica para este mercado foge dos propósitos desta monografia, mas podem ser encontradas nas publicações "Viabilização Jurídica do Mecanismo de Desenvolvimento Limpo" de Flavia Witkowski Frangetto e Flavio Rufino Gazani, Editora Fundação Peirópolis, Brasil, 2002 e no "Guía Metodológica de Valoración Económica de Bienes, Servicios e Impactos Ambientales" de Radoslav Barzev, Nicarágua, 2002.

Observa-se na tabela 1, que os 10 países que mais emitem CO2, respondem por quase $90 \%$ do total da emissão. O CO2 presente na atmosfera é a principal causa do efeito estufa, pois funciona como um vidro de automóvel, permitindo a entrada das radiações solares e impedindo a dissipação do calor.

A emissão de CO2 traduz o grau de industrialização de cada país, e aponta 
também o padrão de consumo de seus habitantes. Naturalmente, a igualdade de desenvolvimento entre os países não pode ser alcançada elevando-se o padrão de consumo dos países menos industrializados, pois o planeta já não suporta os níveis atuais de industrialização. Logo, somente a redução dos padrões de consumo dos habitantes dos países industrializados propiciará o equilíbrio necessário.

A busca por soluções alternativas que satisfaçam as necessidades humanas fundamentais vem gerando soluções inovadoras na redução dos impactos ambientais. O Passive Design, que é um dos conceitos intrínsecos de um Ecolodge, tem atraído a atenção de pesquisadores interessados nesta busca.

O termo Passive Design tem sido traduzido na escassa literatura em língua portuguesa que trata do assunto como Design Passivo. Esta é uma tradução baseada em uma aproximação sonora e não dá conta da abrangência do conceito. Mesmo porque a palavra design não pertence a nossa língua e induz, também por aproximação sonora, à sua limitada acepção de desenho. A palavra design aplicada nesse contexto corresponde a projeto, configuração. E passive tem o sentido de "sem resistência", fluido, "sem perdas". Portanto, Passive Design seria um "Projeto Sem Perdas". Fiquemos, todavia, com a tradução "Design Passivo", que mesmo incipiente, já se consagra. Mas é importante a compreensão do conceito em seus fundamentos.

\section{5 - Design Passivo}

A definição da publicação australiana "Home, Design for Lifestyle \& the Future" (março, 2004, pg. 1) é de que Design Passivo é o "projeto (design) que não requer aquecimento ou refrigeração mecânicos. Casas que são projetadas sem perdas (passively designed) valem-se dos fluxos naturais de energia para manter o conforto termal" (Home, 2004, pg. 1). Trata-se de um novo conceito para uma velha idéia. Xenofonte, em seu "Ditos e Feitos Memoráveis de Sócrates" ( Coleção Os Pensadores, Nova Cultural, 1996, pg. 144) nos apresenta Sócrates peripatetizando:

"-Quando se quer construir uma casa - dizia - não se engenham meios de fazê-la o mais agradável possível? - Uma vez admitido esse princípio: - Não é de desejar seja fresca no verão e quente no inverno? - Acordado este segundo ponto:

- Pois bem, quando as casas olham para o meio-dia, o sol não penetra, no inverno, sob as galerias exteriores, e passando, no verão, por cima das nossas cabeças e dos tetos, não nos deixa na sombra? Portanto, para receberem sol no inverno não hão mister mais altos os tetos das galerias voltados para o meio-dia e mais baixos os dos tetos voltados para o setentrião, a fim de ficarem menos expostos aos ventos frios? Em uma palavra, o prédio que em qualquer estação proporcionar o mais aprazível retiro e o depósito mais seguro para o que se possua, não pode deixar de ser o melhor e o mais belo." 
A definição de Sócrates, que liga a beleza à funcionalidade e ao conforto, condiz exatamente com os princípios do Design Passivo. A escolha do local apropriado, o posicionamento da construção, a observação da direção dos fluxos dos ventos, tudo deve ser projetado objetivando o aproveitamento das forças naturais como produtoras e dissipadoras de energia.

A construção do Ecolodge, que em sua própria definição exige que seja realizada causando o mínimo impacto possível, deve ter seu local escolhido seguindo critérios específicos. Para o clima predominante no Brasil, onde a refrigeração é mais importante do que o aquecimento, é importante encontrar um local com sombras de árvores, pois não existe nada que retire mais calor dos raios solares do que folhas verdes.

Considerar a trajetória do sol é fundamental. Como já foi dito, o efeito do CO2 na atmosfera é semelhante ao causado pelos vidros dos automóveis, que permitem a passagem de radiação solar e impedem a dissipação do calor. Assim, em um microclima, como o interior de uma casa, evitando-se a incidência de raios solares em grandes superfícies de vidro voltadas para leste e oeste, evita-se também um mini efeito estufa. O planejamento de ambientes internos para as diferentes atividades deve considerar que as paredes voltadas para oeste estarão mais quentes pela manhã e as voltadas para leste mais quentes à tarde.

As propriedades barológicas dos gases têm grande aplicação no Design Passivo. As massas de ar se movimentam de regiões mais quentes e de mais pressão para as mais frias e de menos pressão. Tira-se vantagem deste fenômeno construindo os aposentos que devem ser refrigerados com o pé-direito mais alto. A circulação do vento deve permitir uma maior entrada nas regiões baixas da construção e saídas mais estreitas nas partes altas, provocando a dissipação do calor.

A escolha de materiais porosos, que são excelentes isolantes térmicos, para as paredes que recebem raios solares é mais um item a ser considerado no Design Passivo, bem como o uso da água, da sua captação até as suas propriedades de isolamento e dissipação do calor. A água da chuva pode ser captada e armazenada e sua utilização é irrestrita, desde que observados os tratamentos recomendados para cada uso e considerada a proximidade com pólos emissores de gases tóxicos.

A adoção dos princípios do Design Passivo na concepção e realização de projetos ecoturísticos constitui-se não apenas em um cumprimento de especificações de entidades certificadoras internacionais em Ecoturismo, mas também em uma importante ferramenta de educação ambiental.

A evidência da opção por versões menos impactantes de materiais e objetos com funções idênticas é, em si, um veículo de educação ambiental. É a pedagogia 
do exemplo, ou, o aprendizado pela descoberta. É o que os psicólogos da Gestalt deram o nome de "Experiência Ahá!", que é o estado de arrebatamento "que segue ao momento de verdade, ao lampejo de iluminação, quando as peças do quebracabeça se encaixam todas corretamente". (Koestler, 1978, pg 147), uma das formas mais pregnantes de aprendizado.

A apresentação do Design Passivo neste trabalho tem o propósito de indicar que a preocupação com formas menos impactantes de construção já se materializa em projetos que não refletem obrigações ou imposições legais, e sim comportamentos resultantes de um processo de sensibilização para as questões ambientais que ocorre no plano individual.

Deve-se salientar que esta sensibilização já produz reflexões que se por um lado têm uma face acadêmica e com forte fundamentação teórica, por outro agrupam indivíduos em torno de idéias de fácil assimilação como, por exemplo, a Simplicidade Voluntária e os Criativos Culturais.

\section{6 - A Simplicidade Voluntária}

"O equilíbrio se manifesta quando temos o suficiente - nem excesso nem carência material. Para encontrar esse equilíbrio em nossa vida diária é preciso que compreendamos a diferença entre nossas "necessidades" pessoais e nossas "vontades". Necessárias são aquelas coisas essenciais à nossa sobrevivência e crescimento. Vontades são os bens materiais supérfluos - que gratificam nossos desejos psicológicos. (...)

Somente quando conseguirmos distinguir claramente entre o que precisamos e o que queremos poderemos começar a reduzir os excessos, encontrando o meio-termo entre os extremos. Ninguém mais poderá alcançar esse equilíbrio para nós. Trata-se de uma tarefa que nós mesmos teremos de realizar."

(Elgin, 1993, pg. 110)

Este texto, extraído do livro "Simplicidade Voluntária" de Duane Elgin e escrito um ano após a realização da Eco-92, reflete uma nova postura diante das ofertas de consumo. Susana Gastal, em seu livro "Turismo na Pós-modernidade: (Des) Inquietações" precisa o momento histórico da transformação das motivações do consumo:

"A cultura da necessidade será substituída, num outro tempo subseqüente, pelos novos padrões da máquina: a base econômica será a industrial. A fábrica produz em série e em quantidade, uma produção que o mercado deverá absorver também em quantidade. O momento industrial ainda vê surgir novos materiais, entre eles o plástico - e, depois, outros derivados do petróleo - que permitem diversificar ainda mais a oferta de produtos.

Este novo sistema econômico não pode depender apenas das «necessidades» naturais dos consumidores - afinal, o que seria da indústria, se continuásse- 
mos a ter um único vestido no nosso guarda-roupas! - nem das informações difundidas pelo boca-a-boca. Agora, também a informação será massificada e aos vários veículos como as revistas, jornais e o rádio, logo acompanhados do cinema e da televisão, aliar-se-á um parceiro importante: a publicidade. Sua principal função? Criar o desejo - e a necessidade - de mais produtos. Neste novo momento, não mais compramos por necessidade mas por desejo."

(Gastal, 2003, pg 53)

A Simplicidade Voluntária não é propriamente uma invenção, mas uma descoberta, ou mais precisamente, uma redescoberta. É uma reação aos padrões de consumo motivados pelo desejo, como identificou Gastal, e de acordo com o texto de Elgin "Ninguém mais poderá alcançar esse equilíbrio para nós. Trata-se de uma tarefa que nós mesmos teremos de realizar.", ou seja, uma mudança de valores que deve ocorrer no plano individual.

Elgin, em artigo para a revista "Emerging Lifestyles" (primavera de 2003), cita fontes históricas inspiradoras da Simplicidade Voluntária como no cristianismo: "não me dê pobreza nem riqueza, concede-me o pão que me é necessário" (provérbios 30:8), no taoísmo: "aquele que tem o bastante é rico" (Lao Tsu), no budismo, que prega o caminho do meio entre pobreza e acúmulo. A estes podemos acrescentar Sócrates que, como definido por José Américo Motta Pessanha, era "despreocupado com os bens materiais - cujo acúmulo era o objetivo da maioria - , usufruindo os prazeres sem se atormentar em viver à sua cata, mas também sem deles fugir em exageros ascetas". (Pessanha, "Sócrates" - Coleção Os Pensadores, Nova Cultural, 1996)

Os teóricos da Simplicidade Voluntária evocam também como arcabouço teórico o documento "Warning to Humanity", assinado por mais de 1.600 cientistas de várias nacionalidades, incluindo mais da metade dos laureados com o prêmio Nobel. O documento traz advertências sobre vários aspectos que põem em risco a vida no planeta e, em sua seção "What we must do", lista cinco ações urgentes:

We must bring environmentally damaging activities under control to restore and protect the integrity of the earth's systems we depend on. We must, for example, move away from fossil fuels to more benign, inexhaustible energy sources to cut greenhouse gas emissions and the pollution of our air and water. Priority must be given to the development of energy sources matched to third world needs - small scale and relatively easy to implement. We must halt deforestation, injury to and loss of agricultural land, and the loss of terrestrial and marine plant and animal species.

2 We must manage resources crucial to human welfare more effectively. We must give high priority to efficient use of energy, water, and other materials, including expansion of conservation and recycling. 
$3 \quad$ We must stabilize population. This will be possible only if all nations recognize that it requires improved social and economic conditions, and the adoption of effective, voluntary family planning.

$4 \quad$ We must reduce and eventually eliminate poverty.

5 We must ensure sexual equality, and guarantee women control over their own reproductive decisions. ${ }^{4}$

A íntegra deste documento vem sendo divulgada em várias publicações nos mais diferentes formatos, e pode ser encontrada no sítio http://www.deoxy.org/sciwarn.htm, inclusive com os nomes cientistas mais proeminentes que o subscreveram.

Também fazem parte da doutrina da Simplicidade Voluntária as obras transcendentalistas "Ensaios" de Ralph Waldo Emerson (1841 a 1844) e "Walden, a Vida nos Bosques" de Henry David Thoreau (1854). O transcendentalismo foi um movimento religioso nascido na Nova Inglaterra, caracterizado pela "crença na hegemonia da natureza sobre a sociedade, da conseqüente rebelião contra as instituições levando ao refúgio na mãe natureza" (Cabral, Prefácio de Walden, 1984). O transcendentalismo iria influenciar, anos depois, as obras de Allen Ginsberg, William Borroughs e Jack Kerouac, principais autores da geração Beatnik, movimento de contra-cultura americano, também influenciador da Simplicidade Voluntária.

Importa-nos, entretanto, o fato de que os conceitos que norteiam os adeptos da Simplicidade Voluntária são perfeitamente condizentes com os do Ecoturismo, fazendo deste uma das ferramentas capazes de realizar seus objetivos. Mesmo sendo a Simplicidade Voluntária uma ação pessoal, sua disseminação já ganha aspectos de rede, constituindo-se em um mercado que buscará sempre destinos turísticos que têm sintonia com suas convicções.

Devemos manter as atividades ambientalmente danosas sob controle para restaurar e proteger a integridade dos sistemas de que dependemos. Devemos, por exemplo, trocar o consumo de combustíveis fósseis por fontes de energia mais benignas e inesgotáveis para deter a emissão de gases causadores do efeito estufa e da poluição do nosso ar e de nossa água. Deve ser dada prioridade para o desenvolvimento de fontes de energia mais adequadas às necessidades do terceiro mundo - de pequena escala e relativamente fáceis de serem implementadas - . Devemos parar com o desmatamento, com a devastação de terras agricultáveis e com a extinção de espécies vegetais e animais, terrestres e marinhas. de para o eficiente uso da energia, água e outros materiais, ampliando a conservação e a reciclagem. rem a necessidade de melhorar as condições sociais e econômicas, e adotarem e executarem o planejamento familiar voluntário.

4 Devemos reduzir e finalmente eliminar a pobreza.

5 Devemos assegurar a igualdade sexual e garantir o controle das mulheres sobre as decisões de sua própria procriação. 


\section{7 - Os Criativos Culturais}

Seguindo a mesma tendência da Simplicidade Voluntária, os Criativos Culturais já são estimados em 50 milhões de pessoas nos Estados Unidos e 90 milhões na Europa.

A expressão "Criativos Culturais" foi proposta pelos pesquisadores de tendências sociais, os psicólogos Paul H. Ray e Sherry Ruth Anderson para descrever o grupo de pessoas que não se encaixavam em suas categorias de avaliação. Segundo Ray e Anderson, essas pessoas não podiam ser definidas por orientações políticas de esquerda ou direita, nem tampouco serem classificadas nos grupos sociais tradicionalmente identificados. Para sistematizar a nova realidade com que se deparavam, os pesquisadores criaram 3 grupos: Modernos, Tradicionais e Criativos Culturais.

Segundo Ray e Anderson, "a forma mais simples de se entender os Modernos é a de que são cidadãos que aceitam que a mercantilização do mundo urbano-industrial é a forma óbvia e correta de se viver. Eles não buscam alternativas" (Ray e Anderson apud Montagne, 2000). As características mais importantes dos modernos são:

- $\quad$ making lots of money;

- climbing the ladder of success with measurable steps toward one's goal;

- $\quad$ having lots of choices (as a consumer, or voter or on the job);

- $\quad$ being on top of the latest trends, styles and innovations;

- $\quad$ supporting economic and technological progress at the national level;

- $\quad$ rejecting the values and concerns of native people, rural people, Traditionals, New Agers, and religious mystics. ${ }^{5}$

(Ray e Anderson apud Montagne, 2000)

Os Tradicionais foram assim descritos por Ray e Anderson "muitos dos tradicionais não são republicanos "branquelos" (white bread), mas democratas retardatários do new deal, democratas de Reagan, os antigos sindicatos, bem como políticos sociais conservadores..."

5

- Juntam muito dinheiro;

- $\quad$ escalam a escada do sucesso com passos objetivamente calculados;

- $\quad$ têm muitas escolhas (como consumidores, eleitores ou no emprego);

- $\quad$ apóiam o progresso econômico e tecnológico no nível nacional; e

- $\quad$ rejeitam os valores e interesses das populações nativas, rurais, tradicionais, new agers e místicos religiosos. 
Tradicionais acreditam, entre outras coisas:

- $\quad$ "patriarchs should again dominate family life;

- $\quad$ FEMINISM is a swearword;

- $\quad$ men need to keep their traditional roles and women need to keep theirs;

- $\quad$ family, church, and community are where you belong;

- $\quad$ customary and familiar ways of life should be maintained;

- $\quad$ it's important to regulate sex -- pornography, teen sex, extramarital sex- and abortion;

- $\quad$ men should be proud to serve in the military;

- $\quad$ all the guidance you need for your life can be found in the Bible;

- $\quad$ preserving civil liberties is less important than restricting immoral behavior;

- $\quad$ freedom to carry arms is essential;

- $\quad$ foreigners are not welcome." 6

(Ray e Anderson apud Montagne, 2000)

Muitos Tradicionais são sensíveis às questões ambientais e repudiam a destruição das áreas naturais e do modo de vida simples que eles conheceram.

As características dos grupos Modernos e Tradicionais auxiliam a compreensão dos valores dos Criativos Culturais:

- $\quad$ "love nature and are deeply concerned about its destruction;

- $\quad$ are strongly aware of the problems of the whole planet and want to see action to curb them, such as limiting economic growth;

- $\quad$ would pay more taxes or higher prices if you knew the money would go to clean up the environment and stop global warming;

- $\quad$ give a lot of importance to developing and maintaining relationships;

- $\quad$ place great importance on helping other people;

$6 \quad$ - No poder patriarcal sobre a família;

- feminismo é uma blasfêmia;

- $\quad$ homens e mulheres precisam manter seus papéis tradicionais;

- $\quad$ o ser humano pertence à família, à igreja e à comunidade;

- $\quad$ toda a orientação necessária para a vida está na Bíblia;

- $\quad$ preservar a liberdade civil é menos importante do que controlar comportamentos imorais;

- liberdade para portar armas é essencial; e

- $\quad$ estrangeiros não são bem-vindos. 
- $\quad$ volunteer for one or more good causes;

- $\quad$ care intensely about psychological or spiritual development;

- $\quad$ see spirituality and religion as important in your own life but are also concerned about the role of the religious Right in politics;

- $\quad$ want more equality for women at work and want more women leaders in business and politics;

- $\quad$ are concerned about violence and the abuse of women and children everywhere on Earth;

- $\quad$ want politics and government to emphasize children's education and well being, the rebuilding of neighborhoods and communities, and creation of an ecologically sustainable future;

- $\quad$ are unhappy with both left and right in politics and want a new way that is not the mushy middle;

- $\quad$ tend to be optimistic about the future and distrust the cynical and pessimistic view offered by the media;

- $\quad$ want to be involved in creating a new and better way of life in our country;

- $\quad$ are concerned about what big corporations are doing in the name $f$ profit: exploiting poor countries, harming the environment, ownsizing;

- $\quad$ have your finances and spending under control and are not oncerned about overspending;

- $\quad$ dislike the modern emphasis on success, on "making it," on ealth and luxury goods;

- like people and places that are exotic and foreign, and enjoy xperiencing and learning about other ways of life." 7

(Ray e Anderson apud Montagne, 2000)

Amam a natureza e são profundamente preocupados com a sua destruição;

- $\quad$ são fortemente atentos aos problemas de todo o planeta e querem ver ações que os controlem, como a restrição ao crescimento econômico;

- $\quad$ pagariam mais impostos e preços mais altos se soubessem que seu dinheiro iria para correções ambientais e para a interrupção do perigo global;

- dão grande importância ao desenvolvimento e a manutenção dos relacionamentos;

- importam-se muito em ajudar outras pessoas;

- $\quad$ são voluntários em uma ou mais boas causas;

- $\quad$ preocupam-se intensamente com o desenvolvimento psicológico e espiritual;

- Vêem a importância da espiritualidade e da religião em suas vidas mas também são preocupados com o papel dos fundamentalistas cristãos (religious Right) na política;

- $\quad$ querem mais igualdade para as mulheres no trabalho e querem mais mulheres liderando nos negócios e na política; 
Os Criativos Culturais não encontram-se concentrados em uma única faixa de renda nem em regiões específicas. Constituem-se em um nicho de mercado para vários produtos exclusivamente por suas convicções. Wood identifica os Criativos Culturais como público alvo para o Ecoturismo (apresentação em PowerPoint disponível no sítio pessoal em <http://www.eplerwood.com/bio.php>). Todas as projeções indicam para a expansão deste grupo, pois os outros dois grupos são compostos majoritariamente por pessoas mais velhas, com uma maior taxa de mortalidade, e com um fraco apelo junto ao público jovem para sua a renovação.

Os segmentos de mercado com produtos dedicados aos Criativos Culturais é descrito em números expressivos por estudo realizado pelo LOHAS Journal, publicação especializada em comércio consciente - LOHAS é um acrônimo de Lifestyles of Heath and Sustainability .

O segmento de terapias alternativas, incluindo as publicações pertinentes, tem rendimentos de 31 bilhões de dólares ao ano, com estimativas de crescimento de 12 a 15\%. O segmento de modos de vida ecológicos, descrito como informações ambientais e ecológicas, produtos e serviços como, por exemplo, o Ecoturismo, é calculado em 81 bilhões de dólares, com taxa de crescimento de 12 a 15\%. 0 segmento de produtos saudáveis, como alimentos orgânicos, cosméticos e vitaminas rende 32 bilhões de dólares ao ano, e cresce de 15 a 18\% anualmente. 0 segmento de economia sustentável, que abrange as formas de energia sustentáveis, a reciclagem e os investimentos em meio ambiente, lucra 75 bilhões de dólares e cresce $25 \%$ ao ano. (www.lohasjournal.com <http://www.lohasjournal.com>)

Para projetos de Ecoturismo, os Criativos Culturais além de constituírem-se num nicho de mercado para a própria atividade turística, são mercado também para as atividades geradoras de renda complementar. Apesar de não haver pesquisas identificando-os no Brasil, pode-se intuir que eles existam nas mesmas proporções que existem na Europa e nos Estados Unidos, pois trata-se de um fenômeno metro-

\footnotetext{
- $\quad$ são preocupados com a violência e com o abuso de mulheres e crianças em todo o mundo;

- $\quad$ querem que políticos e governo priorizem a educação infantil e o bem-estar, a reconstrução da vizinhança e das comunidades, e a criação de um futuro ecologicamente sustentável;

- $\quad$ estão insatisfeitos com a política à direita e à esquerda e querem um novo rumo que não seja o do centro piegas;

- tendem a ser otimistas sobre o futuro e são céticos quanto a visão cínica e pessimista da mídia;

- $\quad$ querem estar envolvidos na criação de uma nova forma de vida para o país;

- $\quad$ são preocupados com o que as grandes corporações estão fazendo em nome do lucro, explorando países pobres, prejudicando o meio ambiente, causando desemprego (downsizing);

- $\quad$ têm suas finanças e gastos sob controle e não estão interessados em esbanjar;

- desgostam da importância atual do sucesso, do "making if', da posse de luxos e opulências;

- $\quad$ gostam de pessoas e lugares estrangeiros e exóticos e apreciam experimentar e aprender sobre outros modos de vida.
} 
politano, reativo aos padrões de consumos determinados pela Sociedade Industrial, típico de áreas densamente urbanizadas, ocorrentes também no Brasil. Outrossim, a exportação de produtos sustentáveis, logo inesgotáveis, é de extrema importância na balança comercial exterior. A vocação do Brasil para todas as áreas de interesse dos Criativos Culturais é nítida. Como exemplo podemos citar ser o Brasil um dos pouquíssimos países que ainda têm povos isolados no planeta. Não podemos vê-los, mas o simples fato deles existirem em nosso território agrega um enorme valor aos produtos dedicados aos Criativos Culturais.

A sazonalidade é um problema do turismo, em todas as suas modalidades. E no caso do Ecoturismo este problema é particularmente crítico, pois atinge a renda das populações locais, causando frustrações que por vezes põem a perder todo um trabalho de envolvimento participativo. A busca por fontes de renda complementares para estas populações é, portanto, estratégica para o sucesso dos empreendimentos ecoturísticos.

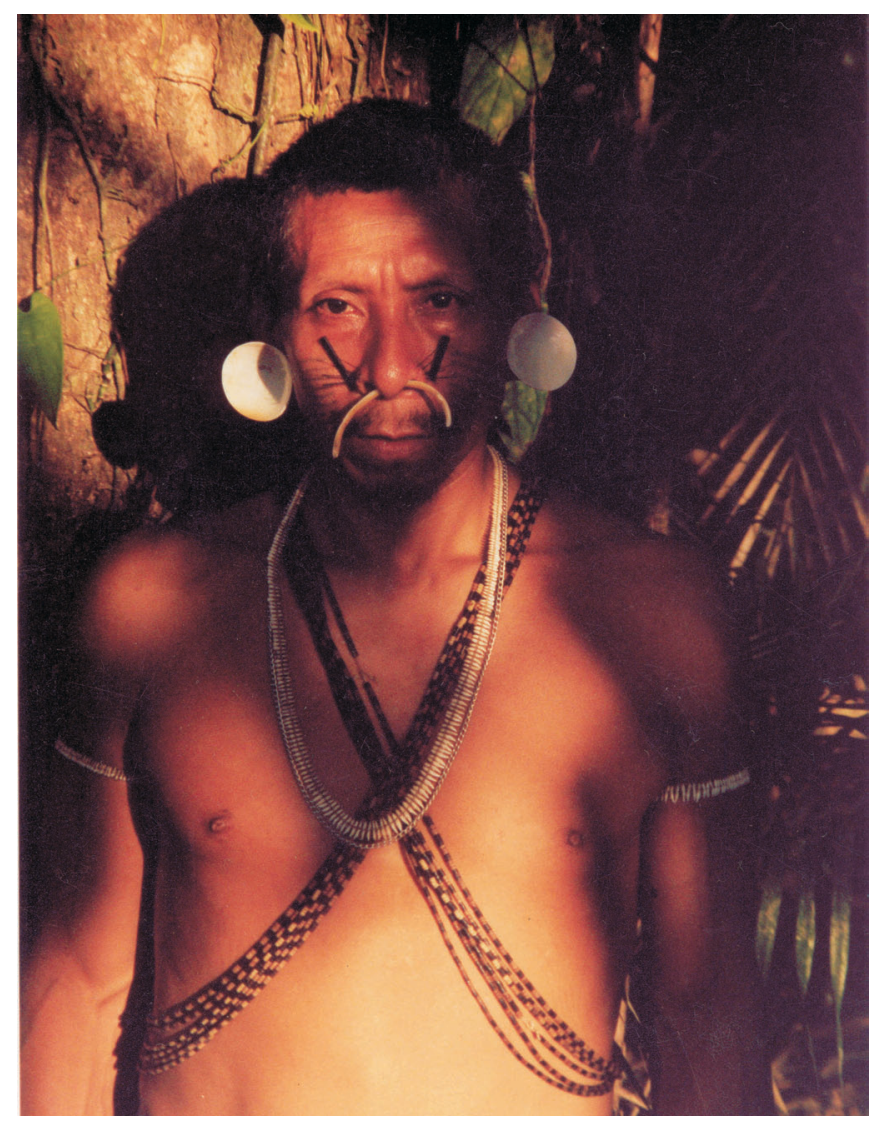

Índio Matis - AM 


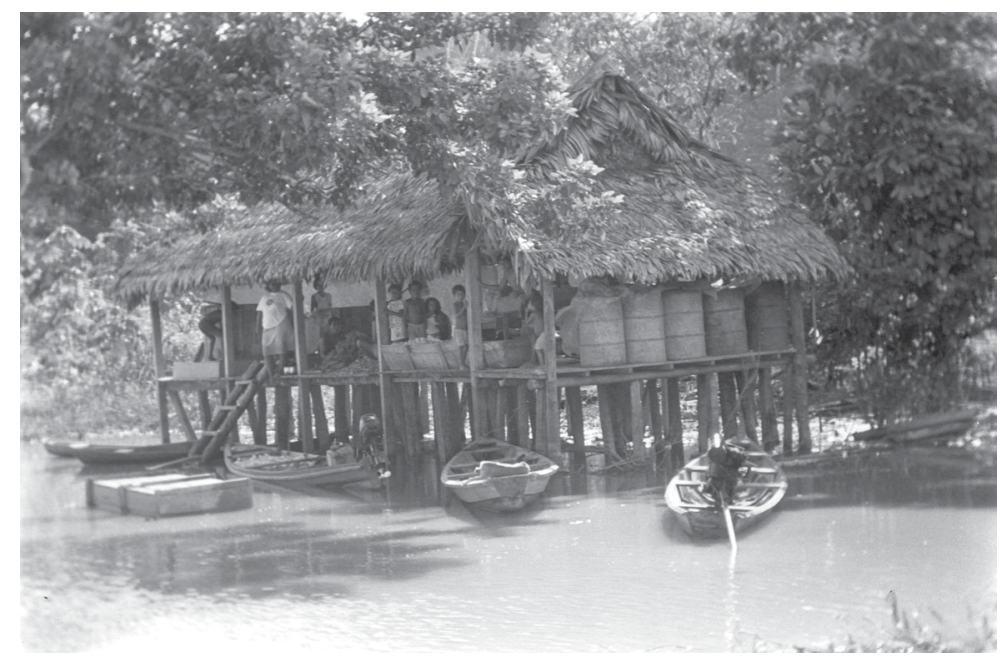

Comunidade Ribeirinha - Produção de farinha - AM

\section{8 - A sazonalidade e o Ecoturismo}

Uma das características da Sociedade Industrial é a sincronização. A produção industrial baseada na linha de montagem, onde todos os operários devem estar ao mesmo tempo em seu local de trabalho, propagou seus efeitos por todos os setores da sociedade. Os turnos de trabalho, as horas de descanso, as férias profissionais e escolares, tudo acontece de forma sincrônica.(Masi, 2000, pg. 57).

A sincronização das férias e dos dias de descanso constitui-se em uma das mais significativas causas da sazonalidade no turismo. Como ação mitigadora, os planejadores do turismo buscam diversificar seu produto concentrando-se principalmente na capacidade ociosa da infra-estrutura turística. O turismo de eventos tem sido a opção preferencial, pois segundo dados da Federação Brasileira dos Convention \& Visitors Bureaux (FBCVB), acontecem 320 mil eventos no Brasil por ano (Comécio Exterior Informe Banco do Brasil, № 50, pg. 24). Fazem parte deste segmento as exposições, campeonatos esportivos, encontros sociais, políticos e religiosos, festas tradicionais, além dos carros-chefes: feiras e congressos. (Informe BB, 2003).

A principal interseção do Turismo de Eventos com o Ecoturismo são as festas tradicionais, tocando as ligações deste com o Turismo Cultural. Ocorre que as festas tradicionais, como o próprio nome indica, refletem um costume, uma celebração já praticada em determinada região. Não se cria uma tradição onde ela não existe. Ou quando se cria, incorre-se no erro de produzir uma manifestação que não parecerá autêntica aos olhos do visitante que, segundo o perfil traçado pela Sociedade Internacional de Ecoturismo (Wood, 2002, pg 23), busca no contato com populações locais, experiências genuínas. Além disso, a exploração de festas tradicionais já foi identificada como potencialmente danosa para as populações locais, que passam a depender da "espetacularização" de suas tradições, estereotipando ritos, laicizando o que era sagrado. (Pellegrini, 1993, pg. 126) 
A sazonalidade em projetos ecoturísticos impacta, sobretudo, a renda das famílias. Considerando a inadequação do Turismo de Eventos para estes projetos, por razões que, além das citadas podem ser encontradas no próprio conceito de Ecoturismo - é dedicado a pequenos grupos em negócios de pequena escala -, resta aos planejadores a busca por atividades complementares que forneçam meios de sustento a estas populações nos períodos de baixa estação.

Por atividades complementares entende-se aquelas que dispensam a utilização da infra-estrutura turística sendo, portanto, uma real diversificação do negócio ecoturístico. O artesanato, desde que a produção possa ser enviada aos pólos emissores de turistas, pode ser considerado uma atividade complementar. Entretanto, caso dependa da visita deste turista para realizar suas vendas, passa a ser um dos componentes da oferta turística, não constituindo-se, propriamente, numa diversificação.

De qualquer forma, qualquer atividade que se pretenda implementar em espaços contíguos a projetos ecoturísticos deve obedecer crítérios de sustentabilidade. A seguir, buscaremos identificar em quais situações as modalidades de turismo Rural e Cultural se assemelham ao Ecoturismo e em quais se distinguem.

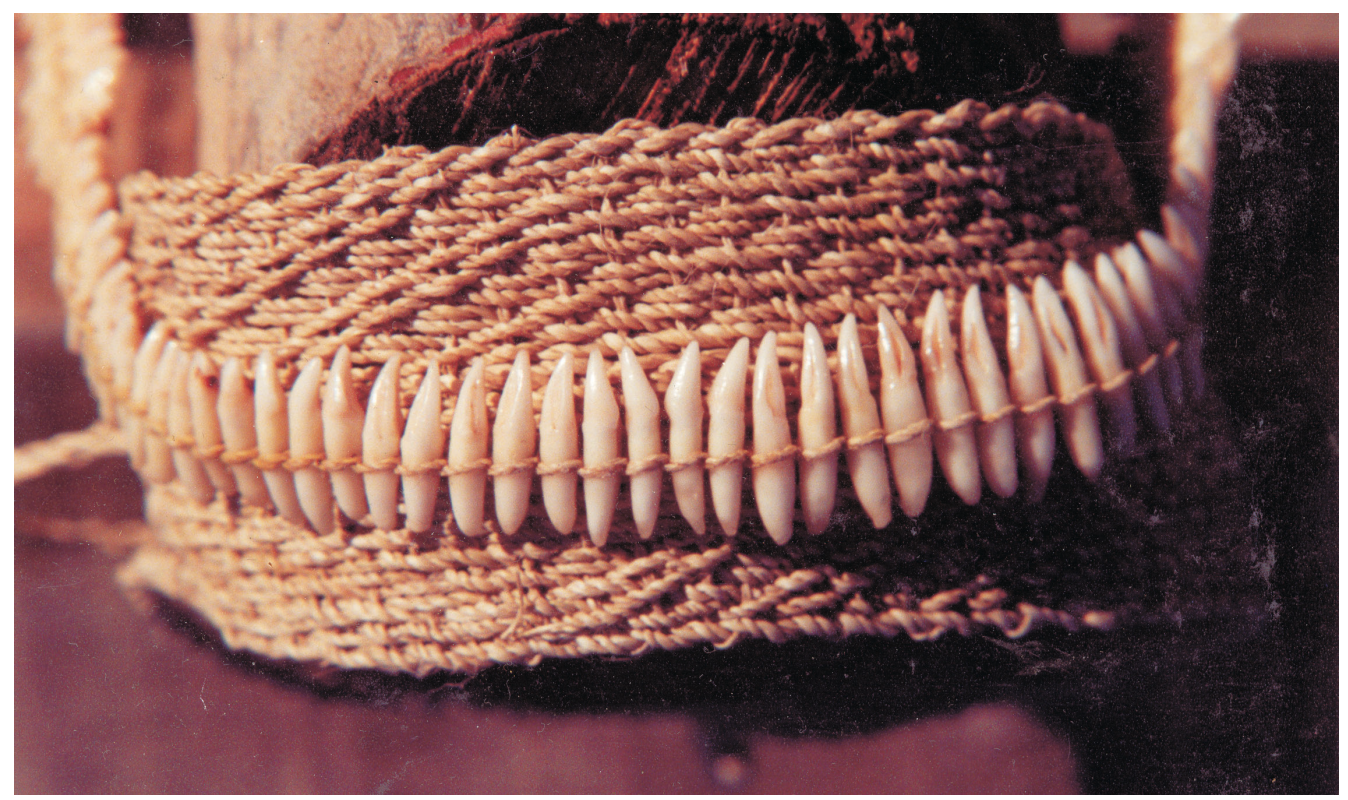

Artesanato Matis - AM 


\section{9 - As conexões do Turismo Rural com o Ecoturismo}

A Associação Brasileira de Turismo Rural é uma entidade de direito privado, com cerca de 1.500 propriedades cadastradas em todo o Brasil. Seus objetivos são:

- $\quad$ "Desenvolver o Turismo Rural no Brasil;

- Desenvolver o Ecoturismo e lutar pela preservação da Ecologia como fonte de vida;

- Divulgar o Turismo Rural junto às operadoras e agências de turismo, órgãos de classe, sindicatos e imprensa em geral;

- Promover o intercâmbio junto às entidades internacionais congêneres e operadoras estrangeiras;

- Defender a preservação da memória rural do Brasil, pela organização de museus regionais e estaduais, com finalidades também turísticas;

- Defender e desenvolver o turismo ecológico nos parques nacionais e estaduais"

(ABTR, em http://www.abtr.com.br/)

A Associação declara também que o Turismo Rural no Brasil baseia-se em 4 conceitos:

- Incremento de Receita

- $\quad$ Geração de Empregos

- $\quad$ Preservação do Meio Ambiente

- $\quad$ Preservação do Patrimônio Rural

(ABTR, em http://www.abtr.com.br/)

A apropriação de um nome que lhe confere caráter oficial por uma Associação privada e a divulgação de seus conceitos de Turismo Rural como sendo os conceitos de Turismo Rural no Brasil, revelam a dificuldade do estabelecimento de uma sistematização para as diversas modalidades de turismo praticadas em ambientes não-urbanos.

A delimitação destas modalidades não é assunto esgotado. Como visto na seção 1 (O Ecoturismo como segmento de Mercado), Megan Apler Wood, oferece uma sistematização do mercado ecoturístico (gráfico 01, Wood, 2002). Esta é a sistematização adotada pelo PNUMA (UNEP) - Programa das Nações Unidas para o Meio Ambiente e pela TIES - The International Ecotourism Society. Olga Tulik, entretanto, entende como simplificação adotar uma única sistematização internacional para realidades diferentes. Para Tulik, a delimitação de espaços urbanos e 
rurais é peculiar a cada país, e constitui-se num debate ainda mais complexo que o da caracterização das modalidades de Turismo. "Os critérios para delimitar essas áreas variam muito e essa diversidade tem sido apontada como a principal dificuldade para se realizarem estudos comparativos e para esclarecerem questões ligadas aos ramos do conhecimento que se apóiam nos conceitos de rural e urbano, como é o caso do Turismo Rural". (Tulik, 2003, pg 22).

De fato, critérios que parecem bem objetivos, quando confrontados com a realidade que buscam organizar, expõe suas vulnerabilidades. No Brasil adota-se o critério político-administrativo, considerando urbana toda área de vila ou cidade com sede, caracterizada por construções, arruamentos e intensa ocupação humana. Também são áreas consideradas urbanas as afetadas por transformações decorrentes do desenvolvimento urbano, e as reservadas à expansão urbana. (Marques, 2002, pg 97). Interesses imobiliários, fiscais, eleitoreiros, e ainda, interesses pela inclusão no Fundo de Participação Municipal, acabam determinando os resultados deste critério, tranformando áreas nitidamente rurais em urbanas.

Seguindo este critério, é considerado rural todo espaço que não é urbano. Veiga (apud Marques, 2002) sugere "o tamanho populacional do município, a sua densidade demográfica e a sua localização" como critérios que evitariam os equívocos causados pelo modelo brasileiro. Argumenta ainda que a densidade demográfica é o critério que melhor diferencia os espaços urbanos e rurais, pois é o indicador que melhor expressa a "pressão antrópica e reflete as modificações do meio natural ou o grau de artificialização dos ecossistemas”. (Veiga apud Marques, 2002, pg 99).

Marques destaca que as definições de cidade (urbano) e campo (rural) relacionam-se a duas principais abordagens: a dicotômica e a de continuum. A abordagem dicotômica baseia-se nas diferenças existentes entre o meio rural e o urbano e a continuum considera "rural e urbano pontos extremos numa escala de gradação", variando a intensidade de influência de um sobre o outro. (Marques, 2002, pg 99)

Para Silva e Almeida, "o espaço rural continua vinculado a agricultura" (Cavalcanti apud Silva e Almeida, 1993, pg. 51),

"mas extrapola a atividade primária. Além de produzir alimentos, o rural assume as funções ambiental, econômica, social e cultural. A própria agricultura expande a função de produzir bens alimentares para desempenhar um papel determinante na manutenção das populações locais, na preservação do ambiente e das paisagens, acolhimento das populações urbanas, entre outros.

(...)

O Turismo emerge dessa situação na medida em que reapropria-se do espaço rural, sob a perspectiva positiva de reduto da cultura simples e vida tranqüi- 
la, ao mesmo tempo em que apresenta-se como uma entre as alternativas de formação de renda familiar"( Silva e Almeida, 1993, pg 51)

É certo, porém, que mesmo que os critérios de classificação de urbano e rural variem conforme o país, o Turismo necessita de uma padronização internacional, pois a oferta comercial é realizada em linguagem publicitária, inadequada para veiculação de reflexões acadêmicas. Por maiores que sejam as distorções causadas pela padronização, os efeitos da adoção de um critério para cada país destino seria muito mais prejudicial para o trade turístico.

As expressões Turismo no Espaço Rural (TER) e Turismo nas Áreas Naturais (TAR) também são utilizadas como sinônimas de Turismo Rural. Tulik cita a obra "Ecoturismo: nuevas formas de turismo en espacio rural", de Oxinalde (1994), onde o autor utiliza "Turismo em Áreas Rurais e Naturais" para definir os novos produtos existentes no mercado como Turismo Rural, Turismo Verde, Ecoturismo ou Turismo Ecológico, Agroturismo, Turismo de Aventura e Esportivo e Turismo Cultural. Tulik explica que o autor conclui que "o Turismo Rural compartilha de todos esses tipos e, o que é mais importante, engloba-os como modalidades que não se excluem, mas se complementam, de tal forma que o Turismo em Espaços Rurais (TER) é a soma de todos os tipos." (Tulik, 2003, pg 33).

Considerar que o Turismo em Espaços Rurais engloba as outras modalidades de turismo praticadas em áreas não-urbanas requer, ao menos, uma organização destas modalidades quanto a sua afinidade umas com as outras. A sistematização de Wood (gráfico 01) considera o Ecoturismo, ao lado do Turismo de Aventuras, uma subclassificação do Turismo em Áreas Naturais, e não estabelece conexões do Turismo Rural com o Turismo de Aventuras. A aceitação desta sistematização por importantes entidades financiadoras e certificadoras (UNEP, TIES) indica a conveniência da adequação dos projetos em Ecoturismo conforme seus parâmetros.

Verbole divide o Turismo Rural em Agroturismo, que se refere a todas as formas de turismo diretamente relacionadas ao ambiente agrário, produtos agrários e habitações agrárias, cujos provedores estão diretamente engajados na agricultura; e o Turismo de Fazendas, com atrativos diretamente relacionados às atividades de uma fazenda.(Verbole, 2002, pg. 117). Esta definição desconsidera um importante aspecto do ambiente rural, que é o grau de interferência do ambiente urbano (industrialização) neste. Tanto o Agroturismo como o Turismo em Fazendas podem conter ingredientes que não satisfarão as expectativas de seus clientes. Um turista que esteja interessado na observação de uma fazenda altamente industrializada, que disponha das mais altas tecnologias para o incremento da produção, certamente se decepcionará com as ofertas de uma população que, mesmo sendo essencialmente agrária, não ofereça a observação destas tecnologias. 


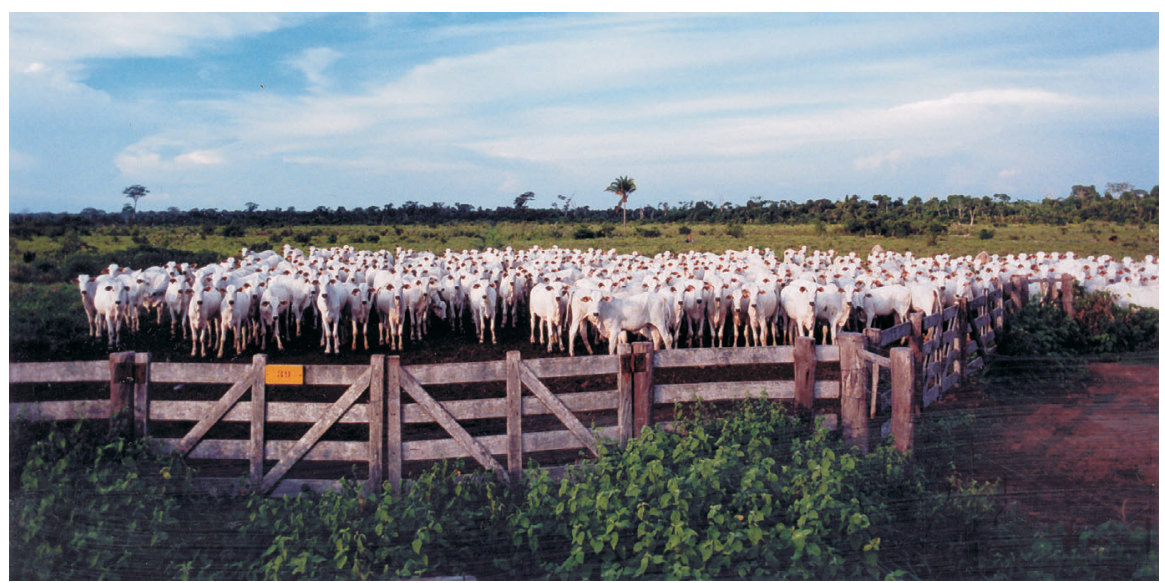

Fazenda Industrial - PA

Os conceitos de Turismo Rural que a Associação Brasileira de Turismo Rural (ABTR) diz serem os conceitos adotados no Brasil estão absolutamente dissociados dos conceitos de Ecoturismo. Ao declarar como um dos conceitos o "incremento da receita", não fica claro quem seriam os beneficiários desta receita.

Tulik, citando Oliveira (2001), identificou 3 diferentes grupos de proprietários de empreendimentos de Turismo Rural:

- $\quad$ Autêntico - Produtor rural residente na propriedade que tem o Turismo Rural como atividade principal ou complementar.

- Sazonal - Proprietário, geralmente turista e de elevado nível sóciocultural, que transformou sua residência secundária num empreendimento de Turismo Rural.

- Investidor - Proprietário sem vínculos com o meio rural, que adquiriu a propriedade para transformá-la numa oportunidade de negócios.

(Oliveira apud Tulik, 2002, pg 80)

Seguindo a identificação dos proprietários de Oliveira, o segundo conceito da ABTR joga luz sobre o primeiro. Ao prever a geração de empregos sem citar a oportunidade de negócios para as populações locais, nem tampouco a sua participação, a ABTR permite que se interprete que seus associados são do tipo sazonal e investidor. O quarto conceito reforça tal interpretação. "Preservar o patrimônio rural" só pode dizer respeito à preservação da posse sobre as áreas rurais, tranformando áreas improdutivas em produtivas por meio do turismo.

O terceiro conceito refere-se a preservação ambiental. A palavra preservação aplicada no contexto do Turismo e do Meio Ambiente tem o sentido de "ações que garantem a manutenção rigorosa das características próprias de um ambiente e as 
interações entre os seus componentes." (WWF, 2003, pg. 438). Barzev define preservação como "manutenção das condições originais dos recursos naturais e do meio ambiente em geral, reduzindo ao mínimo ou eliminando a intervenção humana" (Barzev, 2002, pg. 11). Segundo o SNUC - Sistema Nacional de Unidades de Conservação, preservação é "conjunto de métodos, procedimentos e políticas que visem a proteção a longo prazo das espécies, habitats e ecossistemas, além da manutenção dos processos ecológicos, prevenindo a simplificação dos sistemas naturais." (SNUC, Art. 2ํ, parágrafo $\mathrm{V}$ ).

Conservação, entretanto, é assim definida no glossário do "Manual de Ecoturismo de Base Comunitária", da WWF: "Sistema flexível ou conjunto de diretrizes planejadas para o manejo e utilização sustentada dos recursos naturais, a um nível ótimo de rendimento e preservação da diversidade biológica. Manutenção de áreas naturais preservadas por meio de um conjunto de normas e critérios científicos e legais. Pode ser classificado também como manejo dos recursos naturais de forma a conseguir alta qualidade de vida humana sustentada." (WWF, 2003, pg. 428). Conservação é, para Barzev, "Gestão

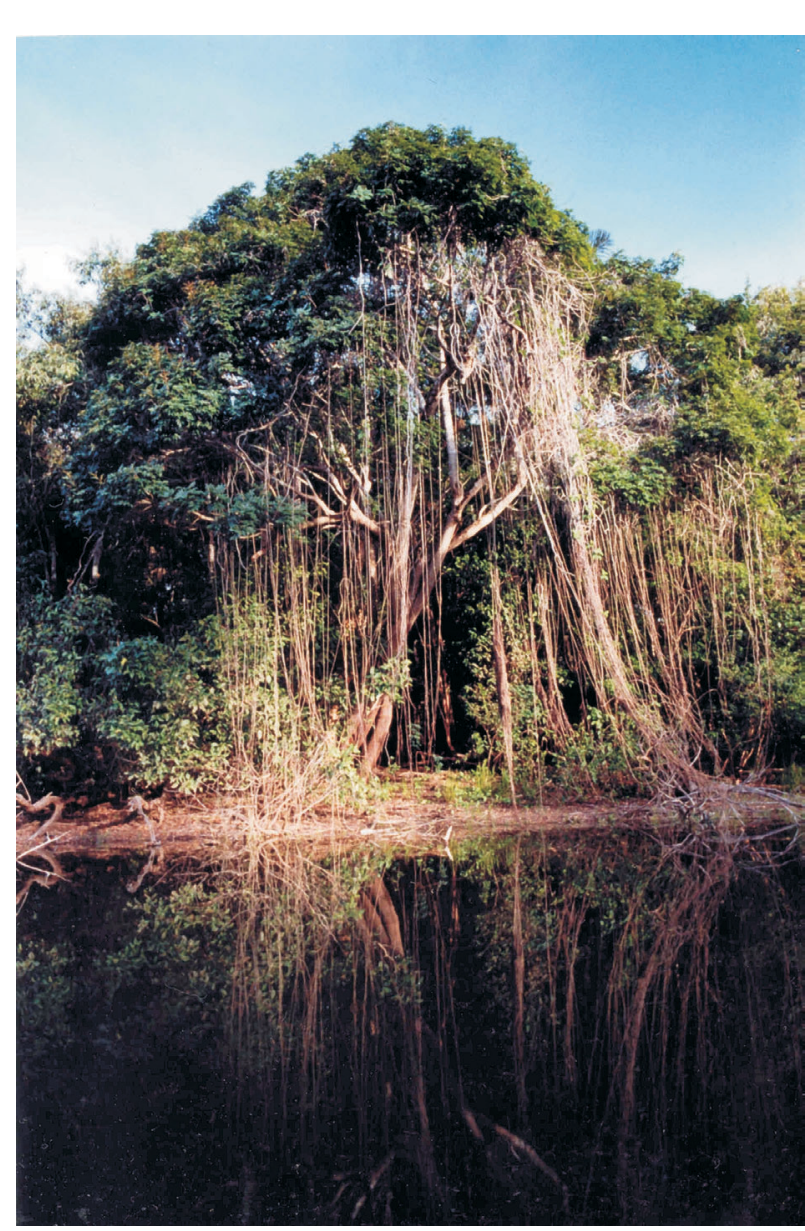

Lago Santa Fé - PA da utilização da biosfera pelo ser humano, de modo que esta gere, de forma sustentável, o maior benefício real, assegurando seu potencial para satisfazer as necessidades das futuras gerações. Compreende ações destinadas a preservação, manutenção, utilização sustentável, restauração e melhoramento do ambiente natural." (Barzev, 2002, pg. 11). O Artigo 2 o do SNUC, em seu parágrafo II, define "conservação da natureza" como "o manejo do uso humano da natureza, compreendendo a preservação, a manutenção, a utilização sustentável, a restauração e a recuperação do ambiente natural, para que possa produzir o maior benefício, em bases sustentáveis, às atuais gerações, mantendo seu potencial de satisfazer as necessidades e aspirações das gerações futuras, e garantindo a sobrevivência dos seres vivos em geral;" (SNUC, Art. $2^{\circ}$, parágrafo II). 
Reside exatamente na distinção entre preservação e conservação os diferentes destinos dados às áreas naturais com diferentes vocações. Em áreas onde se prevê a preservação não é possível o manejo dos recursos naturais para uso do homem, mesmo de forma sustentável. São áreas reservadas para estudos e/ou que visam a proteção do patrimônio genético e de mananciais. Fica clara a confusão de conceitos da ABTR. O Turismo Rural não pode se fundamentar na preservação ambiental, pois isso significa não dispor dos bens ambientais sequer para contemplação. Certamente a ABTR deseja que o Turismo Rural no Brasil tenha a conservação como conceito balizador.

Assumindo a sistematização do mercado turístico de Wood e a abordagem continuum, para a questão cidade-campo, podemos estabelecer as conexões do Turismo Rural com o Ecoturismo. Como visto, Wood diferencia o espaço rural do espaço natural, e a abordagem continuum não se concentra nas diferenças entre a cidade e o campo, mas na quantidade de influência de um sobre o outro. Observando os parâmetros que definem o Ecoturismo adotados por Wood, pode-se inferir que quanto maior a influência dos ambientes urbanos sobre o destino turístico, mais distante estará este destino do Ecoturismo. O destino turístico afasta-se do Ecoturismo na medida em que utiliza métodos industriais de produção, investe na monocultura, na automação dos processos pecuários e agrícolas e não propicia o envolvimento das populações locais em suas etapas de implementação e em suas oportunidades de negócios. É oportuno lembrar que, em muitos casos, o Ecoturismo e o Turismo Rural são oferecidos na mesma propriedade ou em áreas contíguas. Considerando a gradação de influência da cidade sobre o campo, e considerando que o destino preferencial do ecoturista encontra-se no extremo inferior desta influência, o Turismo Rural que tem conexões com o Ecoturismo é aquele que conserva, ou simula com habilidade, o que há de mais rústico e autêntico no ambiente rural. $\mathrm{E}$ é também o que atende as características do Ecoturismo no aspecto de geração de renda e desenvolvimento para as populações locais.

Sendo assim, a valorização da culinária local, as produções agropecuárias diversificadas e consorciadas, o uso do Design Passivo e de técnicas pré-industriais e a valorização da cultura local, são condições necessárias para que o Turismo Rural se harmonize com o Ecoturismo, oferecendo também a experiência interpretativa necessária a realização da educação ambiental.

\subsection{0 - As conexões do Turismo Cultural com o Ecoturismo}

"O conceito de cultura complementa o de sociedade. Definindo sociedade como o que se refere a um conjunto de indivíduos identificados como membros de um grupo social, que inclui minimamente a ambos os sexos e a diferentes gera- 
ções, ou a uma família realizando o processo social total, ou a várias famílias nucleares desenvolvendo relações orgânicas comuns, a cultura refere-se às obras dos homens, portanto, aos conteúdos e símbolos que governam estas relações e que dão significado e continuidade a ação social.

Deste modo, sociedade equivale ao agrupamento orgânico de certo número de indivíduos para propósitos que Ihes são comuns em termos de processo social.

Já a cultura representa as idéias, os conceitos e os valores que regulam coletivamente e individualmente tais relações, transmitidos no processo de socialização, por sua vez criados pela transformação ou invenção, cuja qualidade mais significativa é de ser basicamente homogênea."

(Clerton Martins, 2003, pg 44)

Sendo a homogeneidade uma característica básica para a identificação de uma cultura, o Brasil é, por definição, um país multi-cultural. De fato, de povos autóctones, que são sequer identificados a que tronco lingüístico pertencem, até colônias alemãs totalmente impermeáveis ao ambiente cultural que às cerca, de quilombolas à americanizada elite paulistana, todos habitam o nosso território e são, portanto, considerados brasileiros.

Referir-se à cultura brasileira é referir-se a um processo dinâmico de ocupação de um território, que ocorre através do tempo, e que ainda não chegou a seu fim. A despeito disso, Darcy Ribeiro, em "O Povo Brasileiro" (1995), identifica uma protocélula étnica brasileira, formada nos princípios desta ocupação, diferenciada das características portuguesas e indígenas e que "operaram como núcleos aglutinadores e aculturadores dos novos contingentes apresados na terra, trazidos da África ou vindos de Portugal e de outras partes, dando uniformidade e continuidade ao processo de gestação étnica, cujo fruto é a unidade sóciocultural básica de todos os brasileiros." (Ribeiro, 1995, pg. 270).

Esta protocélula espalhou-se por todo o território brasileiro, em sucessivos processos de adaptação e diferenciação, que ao longo de quatro séculos vêm produzindo as faces da cultura brasileira. Ribeiro sistematiza dessa forma estas faces:

"Elas são representadas pela cultura crioula, que se desenvolveu nas comunidades da faixa de terras frescas e férteis do Nordeste, tendo como instituição coordenadora fundamental o engenho açucareiro. Pela cultura caipira, da população das áreas de ocupação dos mamelucos paulistas, constituída, primeiro, através das atividades de preia de índios para a venda, depois, da mineração de ouro e diamantes e, mais tarde, com as grandes fazendas de café e a industrialização. Pela cultura sertaneja, que se funde e difunde através dos currais de gado, desde o Nordeste árido até os cerrados do Centro-Oeste. Pela cultura cabocla das populações da Amazônia, engajadas na coleta de drogas da mata, principalmente nos seringais. Pela cultura gaúcha do pastoreio nas campinas do Sul e suas duas 
variantes, a matuta-açoriana (muito parecida com a caipira) e a gringo-Caipira das áreas colonizadas por imigrantes, predominantemente alemães e italianos."

(Ribeiro, 1995, pg. 272).

A diversidade cultural brasileira é, portanto, para Ribeiro, produto das diversas adaptações ao ambiente desta protocélula comum.

Com abordagem semelhante, Alceu Maynard Araújo, em "Cultura Popular Brasileira" (melhoramentos, 1973), traça um panorama do folclore brasileiro, delimitando as áreas culturais segundo as técnicas de subsistência, e subdivide estas áreas em regiões culturais.

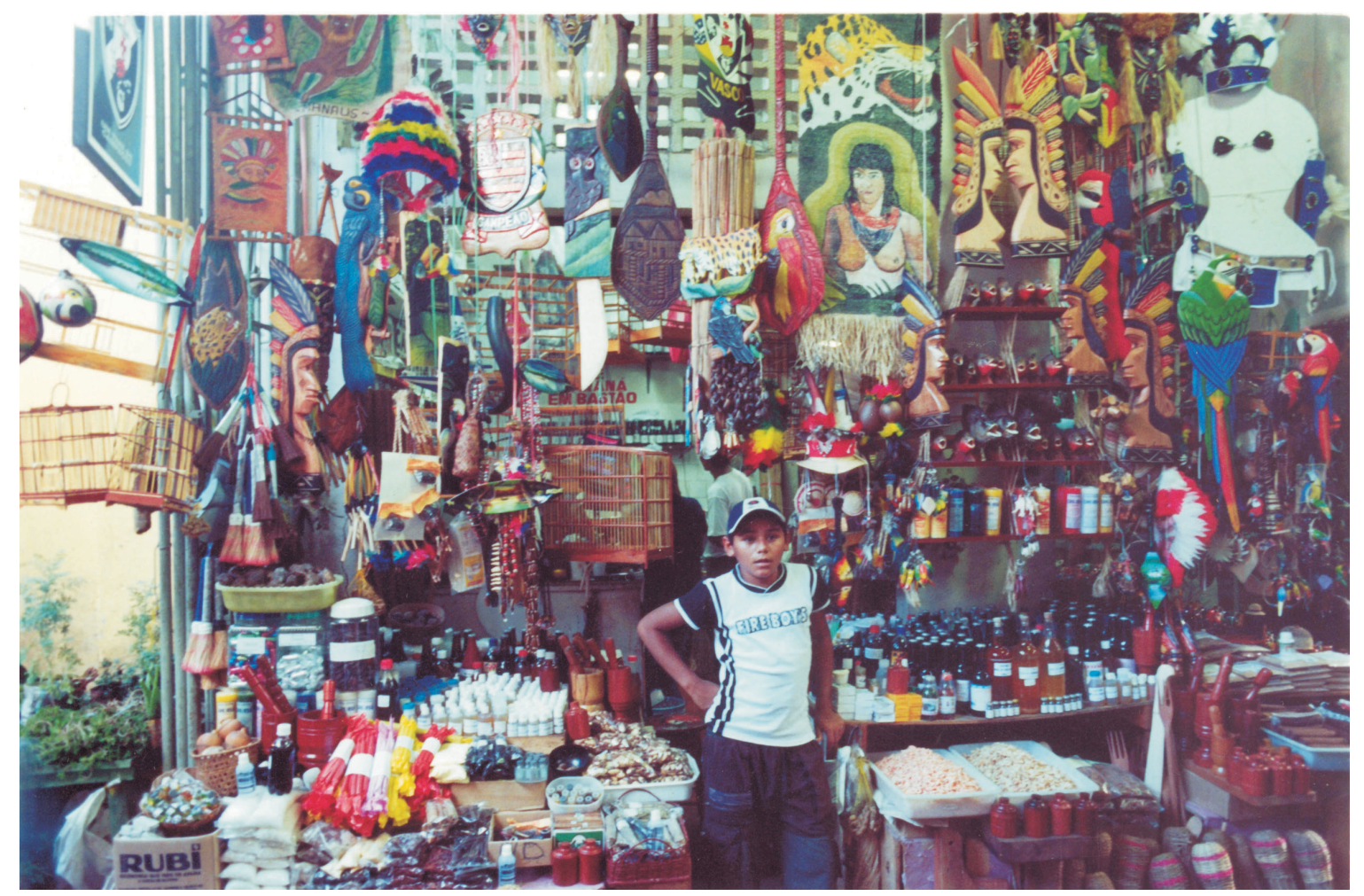

Mercado de Manaus - AM

Segundo Araújo, estas áreas seriam a da Pesca, compreendendo as regiões da jangada e da ubá. Área Agrícola, compreendendo as regiões açucareira, cafeicultora e de novas culturas. Área da Mineração, compreendendo as regiões do minerador e a do garimpeiro. Área Pastoril, compreendendo as regiões do vaqueiro, do campeiro e do boiadeiro. E, por fim, Área Amazônica.

Araújo usa este critério, que em suas próprias palavras é "maleável e plástico", para sistematizar as diversas formas de manifestações culturais do povo brasileiro como as festas, os bailados, as danças, a música, os ritos, a sabença, os mitos e lendas, as artes populares e as técnicas tradicionais.

Estas manifestações, quando realizadas de forma autêntica, constituem-se nas 
áreas de interesse que relacionam o Turismo Cultural e o Ecoturismo. Como visto, os Criativos Culturais, identificados como nicho de mercado para o Ecoturismo, "gostam de pessoas e lugares estrangeiros e exóticos e apreciam experimentar e aprender sobre outros modos de vida" (Ray e Anderson). Este interesse pelo que há de diferente em situações, lugares e pessoas que estejam distanciadas de seu cotidiano é denominado alteridade - definida por Pellegrini como "a busca de assuntos no outro" (Pellegrini, 1993, pg.126) -, e é uma condição importante para que o turismo se realize.

No afã de satisfazer esta expectativa do turista, muitas comunidades tradicionais acabam por oferecer uma encenação de sua própria cultura, situação que MacCannell (1973) chamou de "regiões de bastidores e regiões de fachada", sendo as últimas dedicadas ao consumo do turista. Levada ao extremo, tal situação acaba por esvaziar o interesse do turista por aquele destino, pois, como dito, interessa-o a experiência genuína. Ademais, a falta da prática de seus ritos através das gerações, a não ser de forma simulada, leva tais comunidades ao esquecimento da essência dos mesmos.

Outro aspecto que importa ao turista que busca realidades diferentes das de seu cotidiano é o grau de contaminação das culturas por influências exógenas. $O$ Turismo, como fênomeno que envolve o deslocamento de pessoas, atua como um dos vetores desta influência, pois há sempre uma troca entre visitantes e visitados.

A "Declaração de Ecoturismo de Quebec", documento resultante de um encontro realizado em 2002, com mais de 3.000 mil interessados diretos no desenvolvimento do Ecoturismo, como representantes governamentais, agências de turismo, ONGs, representantes de universidades e de comunidades indígenas e tradicionais "reforça que, quando mal planejada e desenvolvida, a atividade do turismo em áreas naturais e rurais contribui para o aumento da pobreza, ..., erosão das culturas tradicionais, ...". Também em seu parágrafo 29 das recomendações ao setor privado, o documento recomenda "promover entre seus clientes, os turistas,

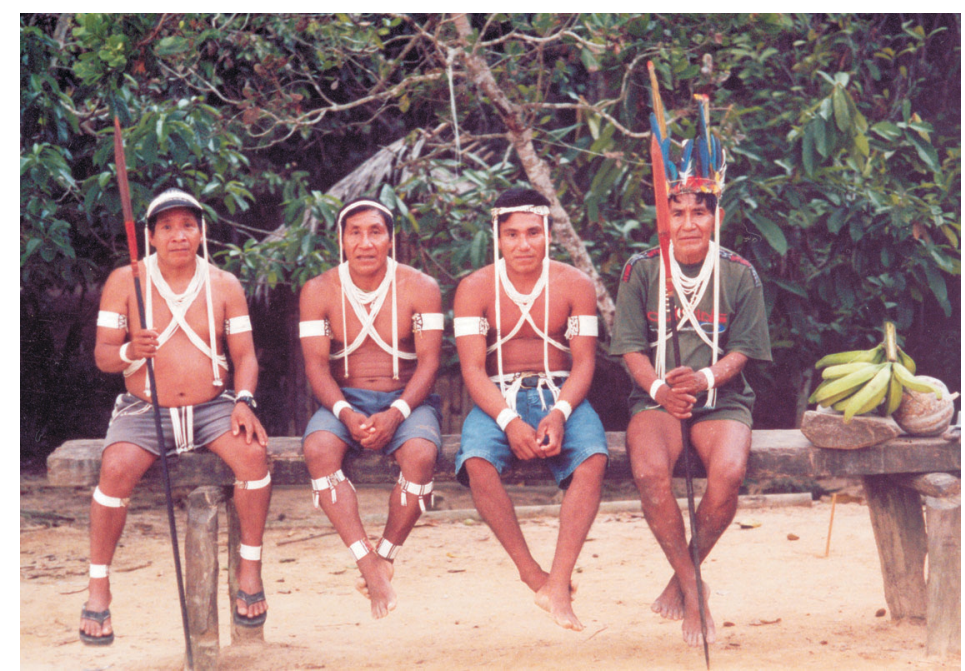

Líderes Marubo - AM 
uma forma consciente de comportamento dando-Ihes a oportunidade de participar de experiências de educação ambiental e de conviver com pessoas de outras culturas. Além disso, contribuições voluntárias às comunidades locais e às atividades de conservação realizadas na região devem ser encorajadas".

Cabe aos empreendedores, portanto, a responsabilidade pelos impactos culturais ocasinados pelo turismo. As trocas, como dito, são inevitáveis. Mesmo com o empreendedor recomendando aos seus clientes um comportamento responsável, o interesse que os hábitos e a parafernália dos turistas provocam nas populações visitadas é enorme, e não se pode negar-Ihes o direito a aprender coisas novas. A busca por mais conhecimento é inerente ao ser humano, populações indígenas e tradicionais não são diferentes. O problema reside menos no que estas comunidades aprendem e mais no que elas desaprendem. A substituição de seus valores pelos dos visitantes é que as leva ao esquecimento de suas tradições.

É oportuno lembrar que muitas soluções e técnicas adotadas por populações tradicionais e indígenas no Brasil são advindas da necessidade imposta pelo seu empobrecimento, causada, muitas vezes, por políticas governamentais que resultaram em abandono destas populações à própria sorte. Os soldados da borracha, por exemplo, nordestinos incentivados a ocupar a Amazônia na segunda Guerra Mundial, hoje compõem, com seus descendentes, uma população ribeirinha marginalizada e excluída.

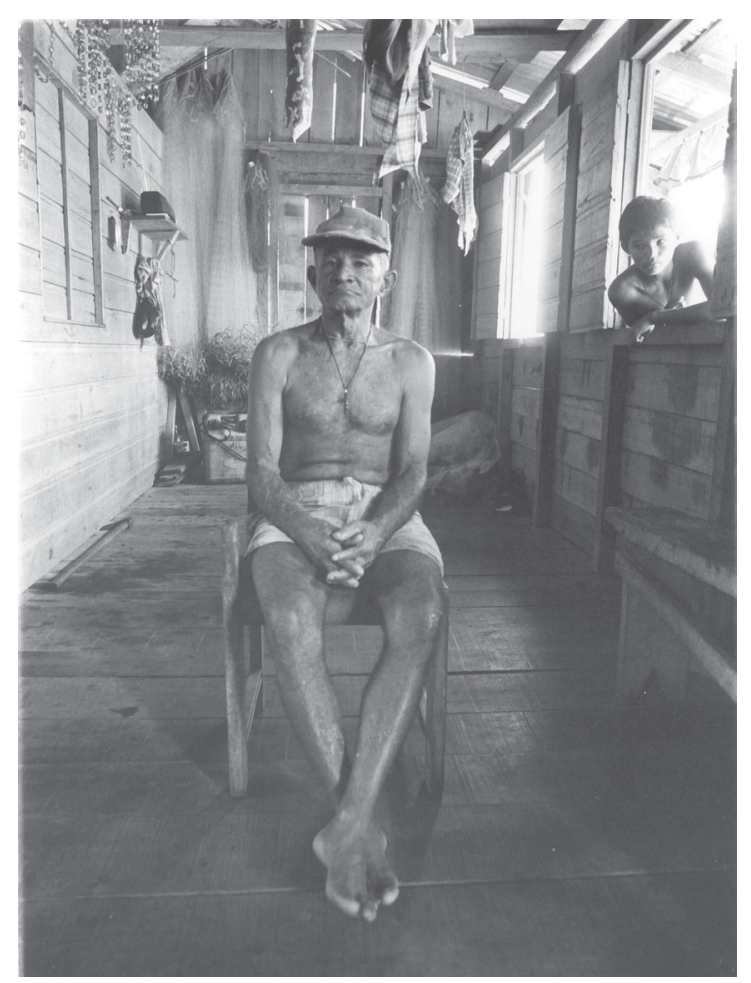

Sr. Gentil - Líder Comunitário - AM 
Os empreendedores e planejadores do Ecoturismo devem concentrar seus esforços no resgate das tradições destas populações. E reforçar-Ihes o entendimento de que é o seu modo de vida singular que atrai o visitante.
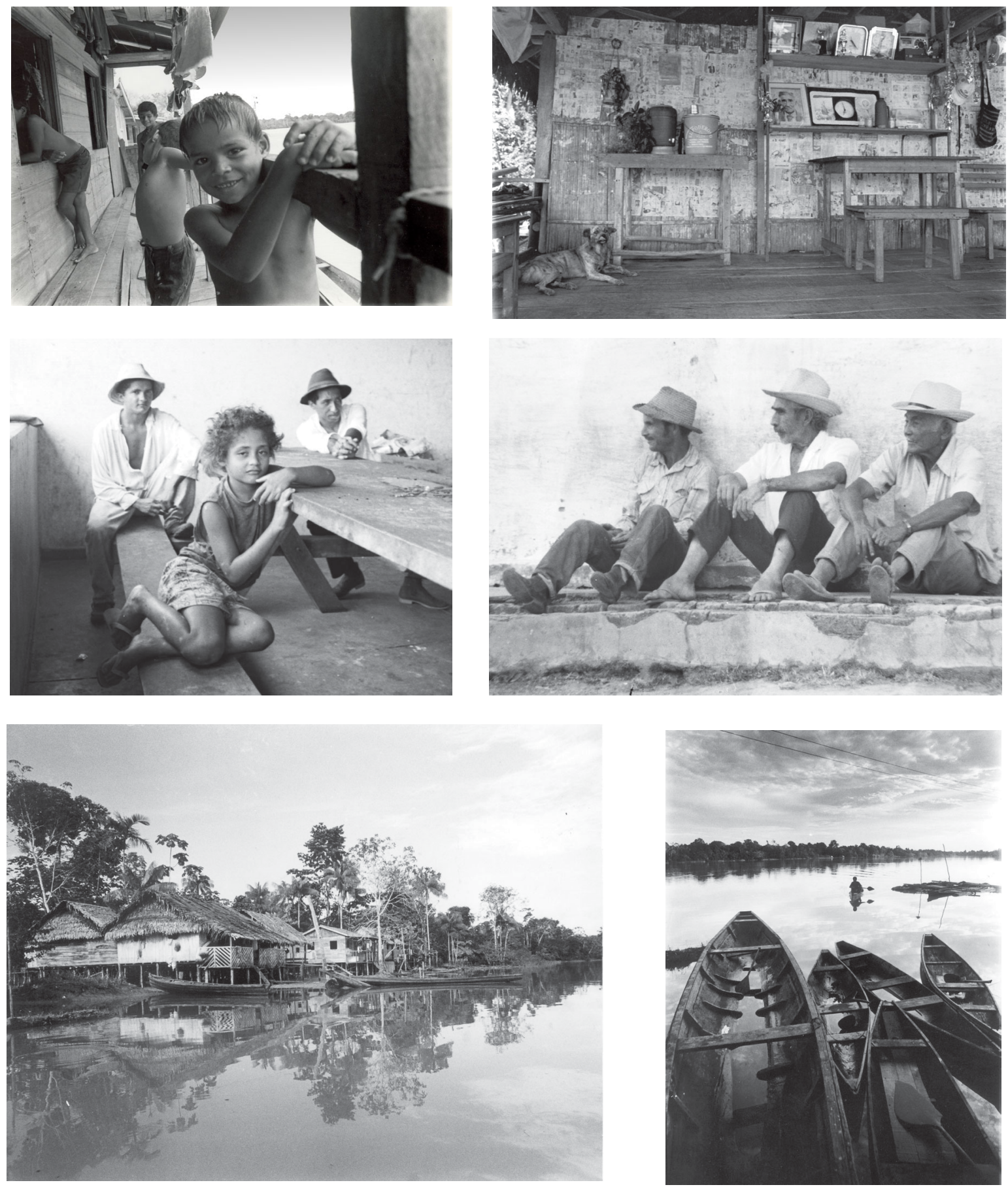

Vida Simples - Mesmas condições do século XIX 


\section{2 - Sobre a obra e seu autor}

\section{1 - Sobre o livro Tesouro das Famílias}

Como visto, não se pode confundir o Ecoturismo com o Turismo de Aventura, onde os praticantes buscam, nos ambientes naturais, sua dose necessária de adrenalina. Inúmeras atividades do Turismo de Aventura envolvem o risco físico de seus adeptos, portanto, é desejável e, em alguns casos, indispensável, o uso da mais alta tecnologia disponível. Por outro lado, o ecoturista, ao sair dos ambientes urbanos em direção aos ambientes naturais, busca a sua religação com a natureza. Sai à procura de um espaço que a cidade Ihe tomou. Trafega da civilização para o bucólico em um processo análogo a uma viagem no tempo, cujo objetivo fosse chegar a uma época em que o homem ainda não houvesse colocado sua marca em todas as coisas, ou que, pelo menos, suas marcas fossem mais suaves.

Planejadores e empreendedores em Ecoturismo devem estar atentos a este componente do imaginário dos seus potenciais clientes. A atenção aos detalhes é que farão do seu empreendimento um destino único. Quanto menor for a evocação dos espaços urbanos, notadamente caracterizados pelos artefatos e materiais que os compõem, mais autêntica será a experiência de seu cliente. Não se sugere aqui o comprometimento do conforto, e sim a busca por alternativas que muitas vezes encontram-se nas próprias etapas da evolução histórica dos objetos. Desta forma, um sistema natural de refrigeração, baseado nos modernos conceitos de Design Passivo, é mais apropriado ao Ecoturismo do que o ar-condicionado. Uma roda d'água é preferível a uma bomba hidráulica movida a diesel, e assim por diante.

Recriar ambientes rurais de épocas remotas exige referências históricas precisas. Assim como restaurar o patrimônio cultural, que nas palavras de Américo Pellegrini, pode ser modernamente definido como "...todo e qualquer artefato humano que, tendo um forte componente simbólico, seja de algum modo representativo da coletividade, da região, da época específica, permitindo melhor compreender o processo histórico. Trata-se, então, de uma problemática posta no âmbito da antropologia cultural, e que podemos enquadrar no amplo significado de ecologia cultural" (Pellegrini, 1993, pg. 94).

Sob esta perspectiva, o resgate de técnicas de conservação de alimentos, horticultura, arboricultura, vernizes e mais inúmeras referências a um Brasil anterior ao uso das máquinas, contribui para a compreensão da realidade em que estavam inseridos estes artefatos históricos.

Buscando temas relevantes na obra Tesouro das Famílias, de Pierre Victor Renault (1810-1892), pretende-se fornecer subsídios para que o conhecimento histórico materialize-se em projetos que transformem a experiência ecoturística em um 
singular encontro com um mundo menos tecnológico e, em muitos aspectos, mais sustentável. Porém, o objetivo fundamental da divulgação desta seleção específica de receitas do Tesouro das Famílias é o seu resgate para uso por populações que, ainda nos dias de hoje, sobrevivem nas mesmas condições que Renault experimentou. A distância de centros urbanos e o baixo poder aquisitivo destas populações tornam tarefas simples, como a conservação de alimentos e a impermeabização de aposentos, em desafios determinantes à sobrevivência.

A obra de Pierre Victor Renault, Tesouro das Famílias, é assim descrita no Diccionario Bibliographico Brazileiro, de 1902, de Augusto Victorino Alves Sacramento Blake:

"Colleção de 1.952 receitas utilissimas e necessarias a todas as classes da sociedade, sobre economia domestica, sciencias, artes, industria, officios, manufacturas, agricultura, industria agricola, horticultura, arboricultura, medicina domestica, propriedade das plantas indigenas e exoticas, alveitaria, etc, etc. Obra extrahida e copiada dos autores os mais afamados e os mais modernos de todos os paizes e augmentada de muitas e variadas receitas privadas e ineditas" (Blake, 1902, pg. 356).

Eça de Queiroz, em Crime do Padre Amaro (1875), no capítulo XXI, faz a seguinte referência:

“(...)As conversas do abade, falador incansável, entretinham-na, tão diferentes dos mexericos da Rua da Misericórdia, - como o espetáculo dum largo vale com árvores, plantações, águas, pomares e rumor de lavouras, recreia os olhos habituados às quatro paredes caiadas duma trapeira da cidade. Tinha com efeito uma destas conversações semelhantes aos jornais semanais de recreio, o TESOURO DAS FAMÍLIAS ou as LEITURAS PARA SERÕES, em que há de tudo doutrina moral, histórias de viagens, anedotas de grandes homens, dissertações sobre a lavoura, citação duma boa chalaça, traços sublimes da vida dum santo, um verso aqui e além, e até receitas, como uma muito útil que deu a Amélia para lavar as flanelas sem encolherem. Só era monótono quando falava da sua família paroquiana, dos casamentos, batizados, doenças, questões, ou quando começava as suas histórias de caça." (Queiroz, 1875).

Também Sir Richard Burton, orientalista, explorador, aventureiro, tradutor, escritor e até agente secreto da Grã-Bretanha, teve contato com Pierre Victor Renault. Richard Burton foi o primeiro tradutor dos Lusíadas, das Mil e Uma Noites e do Kamasutra para o Inglês. Sendo as duas últimas, as traduções pioneiras no mundo ocidental. Seu prestígio o trouxe ao Brasil, onde exerceu o cargo de Cônsul, na cidade de Santos. Do período em que viveu no Brasil, 1865 a 1868, Sir Burton deixou escrito o livro Viagem do Rio de Janeiro a Morro Velho (1868). Em sua passagem por Barbacena, Sir Burton conhece Victor Renault, que o ciceroneia na região. 
"Uma feliz inspiração induziu-me a procurar o Dr. Pierre Victor Renault de Sierck, vice-cônsul da França, médico homeopata e professor de Matemática, Geografia e História em Barbacena. Estando há trinta e quatro anos no Brasil, ele conhece, como a palma da mão, todos os recantos de Minas Gerais, especialmente no que se refere aos rios Paracatu e Doce. E viveu entre as tribos mais selvagens, cujos idiomas aprendeu. Foi tesoureiro da mina de Morro Velho e, entre 1842 e 1843, trabalhou com o Sr. Halfeld na construção da estrada de rodagem. Casou-se com uma brasileira e todas as pessoas importantes da cidade são seus compadres ou comadres. Quem melhor eu poderia desejar para servir-me de cicerone? Embora meio inválido, em conseqüência das muitas viagens e acampamentos, o Dr. Renault, amável e cordialmente, colocou-se à nossa inteira disposição, pegou a bengala e nos levou para ver a cidade." (Burton, 1868, pg. 113)

Sir Burton encontrou em Victor Renault um homem bastante vivido. É importante conhecer um pouco de sua história, pois dela origina toda a sabedoria que resultou na sua obliterada obra Tesouro das Famílias.

\section{2 - O autor, Pierre Victor Renault.}

A vinda de Victor Renault para o Brasil, em 1832, não foi um ato voluntário. Suas afinidades com as idéias republicanas, em um período em que a monarquia buscava a todo custo manter-se no poder, levaram seu pai, Pierre-François, a entender que seu filho correria riscos não só na França, mas também em qualquer colônia francesa. Assim, em 16 de junho daquele ano, o jovem Pierre Victor, então com 21 anos, desembarca no Rio de Janeiro, consciente de que dificilmente reveria sua pátria e sua família. (Maraux, 2000).

Sua carta para seu irmão Léon, escrita 45 anos depois, revela a vida de um autêntico explorador, dotado de um espírito industrioso e empreendedor, cioso do respeito pelas etnias naturais da terra que o recebia.

Na carta, Renault relata que logo após sua chegada ao Rio de Janeiro, ingressou em uma caravana com destino a Minas Gerais para empregar-se em uma mina de ouro como engenheiro. Após 3 meses de viagem, Renault chega ao seu destino e descobre que a mina havia sido comprada por uma companhia inglesa cuja política era a de contratar apenas seus compatriotas.

Desorientado, já sem o dinheiro que havia trazido da França, Renault vaga durante dois anos pela região, chegando até a vender a própria roupa do corpo para se alimentar. Além de todas as privações, Renault ainda trazia uma forte inflamação no fígado, que the foi tratada em uma casa de família, em troca da alfabetização da criança da casa.

Após conseguir se deslocar até Sabará, Renault ali se fixa, lecionando francês, inglês, química, física, matemática e alemão. Nesse ínterim, Renault consegue um 
trabalho temporário como contador em uma mina de ouro em Morro Velho. Findo esse período, Renault, com uma pequena reserva financeira acumulada, parte para se apresentar ao presidente da província para conseguir um emprego como engenheiro.

A oferta do presidente, que paradoxalmente the recomendava não aceitar, era a de que Renault empreendesse expedição pela terra habitada por índios antropófagos botocudos, para encontrar área própria para degredo.

Após percorrer 200 léguas $(1.320 \mathrm{~km})$ com um pequeno pelotão cedido pelo presidente da província, Renault chega a Minas Novas, última parada antes de adentrar a floresta, onde se reabastece e ouve novos alertas sobre os perigos iminentes. Sem realmente nada a perder, Renault dá curso a sua missão. Não tarda a acontecer o primeiro ataque de índios Nak-Nanuk. Após alguns dias de cerco, e não havendo reação por parte dos invasores, os índios se acalmaram e partiram para um contato amistoso.

Renault valeu-se de um intérprete para convencer os índios de suas boas intenções e oferecer-lhes presentes. Logo Renault constata que os relatos de que se tratavam de índios negros era devido ao uso de jenipapo por todo o corpo. Renault permanece junto aos Nak-Nanuk por três meses, aprende sua língua e organiza um vocabulário, publicado posteriormente pelo Conde de Castelnau. Entre inúmeras observações interessantes, Renault relata a vaidade das mulheres em suas criativas combinações de formas de desenho sobre o corpo, usando o jenipapo e o urucum.

Renault diz a seus novos amigos que deve partir, pois sua viagem está apenas começando, e é acompanhado pelos índios, que caçavam e pescavam para todos, durante os 30 dias seguintes. Um dia, ao acordar, Renault percebe que os índios o haviam abandonado e deduz que já se encontrava no território dos Teperok, inimigos ferozes dos Nak-Nanuk. Não tarda a acontecer um novo ataque contra seu pelotão. Só que, desta vez, Renault encontra-se acuado contra um rochedo e a quantidade de índios a atacá-lo é enorme. Durante 23 dias, já sem os seus víveres e alimentando-se de raízes para sobreviver, o pelotão de Renault sofre 0 ataque indígena sem desferir um único tiro de fuzil.

Após este período, e com 13 baixas entre seus homens, Renault recebe a visita pacífica do chefe Teperok, que lhe reconhece como "mangattône ourouje" (muito valente). Sua estada entre os Teperok foi mais conflituosa do que entre os Nak-Nanuk, precipitando a decisão de Renault de abandonar com maior brevidade o local. Para isso, Renault e seus homens providenciaram canoas feitas de troncos para navegarem o rio descoberto por eles e que Renault resolveu manter seu nome indígena, Mokury (Mo = vá, Kury = lavar).

Navegando em um rio desconhecido com canoas precárias, Renault ia 
mapeando a região usando apenas papel, lápis, uma bússola e um teodolito. Um novo ataque indígena e uma queda das embarcações numa cachoeira fizeram o grupo perder seus últimos víveres e equipamentos. A alimentação em seus 16 dias restantes de navegação até o mar foi exclusivamente constituida por frutos de sapucaia que boiavam no rio.

Ao chegar à foz do Mucuri, Renault deparou-se com uma aldeia cujos habitantes desconheciam ser o Mucuri um rio. Acreditavam se tratar de um lago, que eles não exploravam por medo dos botocudos. Neste ponto de sua carta, Renault estabelece uma distinção entre os nativos da região. Os dóceis, cultivadores e "nada maus" ele chama de "Índios" e cita os Puri e os Malache; e os "Botocudos", "raça feroz, nômade e antropófaga", como os Nak-Nanuk e os Teperok. Renault identifica algumas diferenças entre as "raças" como o cultivo da mandioca e o hábito de dormir em redes por parte dos "Índios", enquanto os "Botocudos" dormiam no chão e, sendo nômades, nada cultivavam.

Sua viagem, feita quase em sua totalidade com os pés descalços e com apenas uma calça e uma camisa (lavadas alternadamente), chegava ao fim. Ou meIhor, chegava ao seu meio, pois ainda era necessário retornar e relatá-la ao presidente da província.

Sem a opção de retornar pelo mesmo caminho, pois os rios já estavam cheios, Renault decide voltar pela costa marítima, levando 18 meses para chegar até Ouro Preto, a capital da província. Nesta viagem, seu maior inimigo foi a sede.

Seu trabalho foi recebido com grandes elogios pelo presidente da província. Renault, então, aceita uma nova incumbência do presidente e parte para nova expedição nos rios Paracatu e São Francisco, deixando seus planos de colonização e navegação do Mucuri para que outro obtivesse apoio do governo para sua viabilização. Ao retornar, seu "amigo" havia vendido seus projetos, planos e orçamentos a um particular, que com eles organizou uma companhia. Renault não aponta quem seria este "amigo", nem o comprador dos projetos, mas é um interessante objeto de pesquisa a apuração de quem foram os beneficiários da Companhia de Navegação do Alto do Mucuri.

Renault é incubido ainda de fazer uma estrada de Ouro Preto até o Rio Garnier (?), e finalmente, fixa residência em Barbacena. Casa-se, em 1842, com Antônia, filha do médico que o tratou de uma "febre palustre" contraída ainda na expedição ao Mucuri.

Por razões políticas, Renault perde seu emprego de engenheiro adjunto, mas recupera em seguida, sendo promovido a engenheiro em chefe. Cargo que ele exerce por pouco tempo, pois sua saúde já não permitia as grandes cavalgadas exigidas pela profissão. 
Renault torna-se um grande pesquisador de medicina homeopática, realizando curas em toda região, o que lhe encoraja a fazer um exame livre e a diplomar-se em medicina no Rio de Janeiro.

De volta a Barbacena, Renault desfruta de grande prestígio como médico, mas sua saúde continua a lhe impedir de realizar as viagens necessárias ao trabaIho, e as curas em Barbacena não Ihe rendiam dinheiro algum, pois "São todos compadres, amigos aos quais não posso pedir nada" (Renault, 1877), afirmação que confirma citação anterior de Sir Burton. Torna-se também um expert na arte da jardinagem, o que the vale mais algumas linhas de Sir Burton:

"Em seguida, visitamos o jardinzinho do Dr. Renault, atrás da casa, cuja vegetação é um espelho do clima temperado; o jardim está repleto de cravos, rosas, violetas e verbenas, gladíolos e heliotrópios. As laranjas são excelentes e, com elas, nosso cicerone faz o seu "Tokay"; sai a cerca de quatro pence a garrafa e é, segundo diz ele, a melhor bebida para ser tomada com o pinhão." (Burton, 1868)

Renault relata ao final de sua carta que Antônia Ihe deu 14 filhos, dos quais 8 permaneciam vivos e que tira seu sustento curando a loucura com plantas, dizendo ter 16 casos de cura que lhe deram grande reputação. Renault encerra sua carta em tom melancólico:

Eu teria querido publicar todas as minhas viagens e as descobertas que eu fiz, mas eu não tenho mais energia e esta carta já me cansou muito. Talvez meus filhos acharão algumas notas minhas, as quais eles poderão aproveitar. Eu vivo então mais ou menos o dia a dia, mas eu vivo e eu tentarei a cura de um outro louco quando eu tiver curado aquele que eu tenho atualmente em casa.

Ainda uma vez, eu abraço minhas irmãs e minhas cunhadas, e sou teu irmão que te ama.

(Victor Renault, 1877)

Tradução coordenada por João Carlos Renault em DEZ/1996

Pedro (Pierre) Victor Renault morreu dia 17 de outubro de 1892 em Barbacena-MG. 
Foto: Pedro Victor Renault - Fonte:MARAUX, Vincent, Pierre Victor Renault - Um pioneiro Francês no Século XIX, Virtual Books, 2000

Certidão de Óbito - Dagama Editora

\section{REPÚBLICA FEDERATIVA DO BRASIL}

Estado do

Minas Gerais

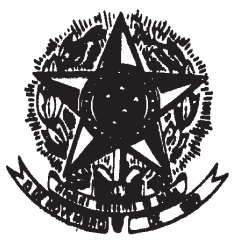

Rogistro Civil

10. Subdistrito

de Barbacena

escriva Bela. Janete Kalil Salles

\section{Certidão de Registro de Óbito}

CERTIFICA que, do livro $n .01 \times x \times$ do Registro de Obitos,

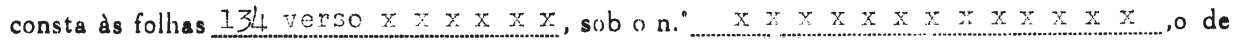

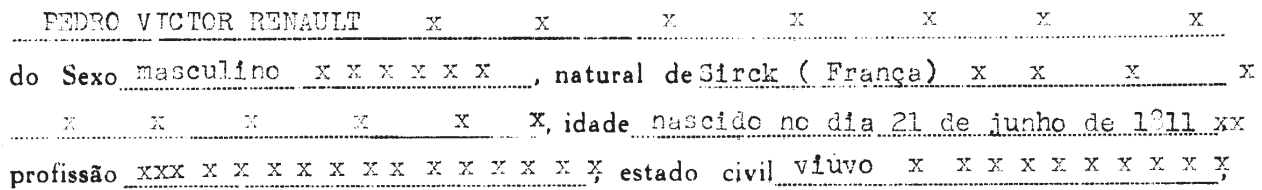

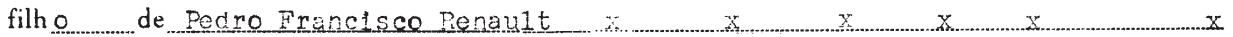
e deMaria Ilzaboth de Meringer $x \quad x \quad x \quad x \quad x \quad x \quad x$ $\begin{array}{llllll}x & x & x & x & x & x\end{array} \quad x \quad x$

Faleceu às $x \times x \times$ horas do dia dezessete $x x y x$ do mês de cutubro $x x x$ de mil ottocentos e noventa $e$ dots $(19 \rho) \quad x \quad x \quad x \quad x \quad x \quad x \quad x$ em consequência de Congestão Gerebral $x \quad x \quad x \quad x \quad x \quad x \quad x \quad x \quad x$

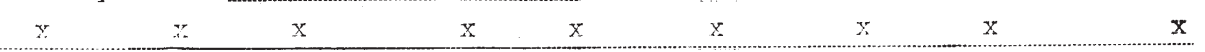

conforme atestou o Dr..ngo consta no termo $x \quad x \quad x \quad x \quad x \quad x \quad x \quad x \quad x \quad x \quad x$

$O$ cadáver foi sepultado no cemitério de ria consta no termo $x \quad y \quad x \quad x \quad x \quad x$ \begin{tabular}{llllllllll}
$\mathrm{X}$ & $\mathrm{x}$ & $\mathrm{X}$ & $\mathrm{X}$ & $\mathrm{x}$ & $\mathrm{X}$ & $\mathrm{X}$ & $\mathrm{x}$ & $\mathrm{X}$ & $\mathrm{x}$ \\
\hline
\end{tabular}

O referido é verdade e dou fé.

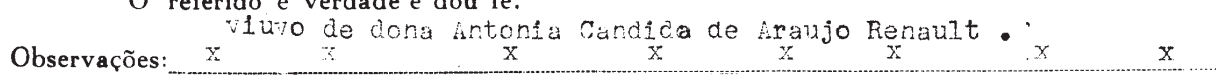

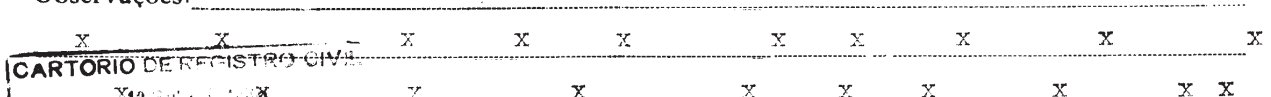

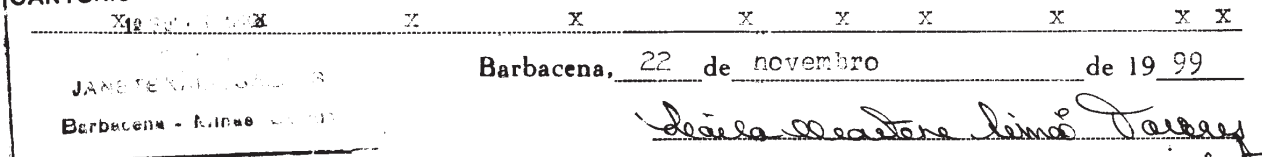




\section{3 - A obra "Tesouro das Famílias"}

\section{1 - Receitas, métodos e procedimentos do Tesouro das Famílias}

As receitas, métodos e procedimentos que serão expostos a seguir foram extraídas do livro Tesouro das Famílias, de Pierre Victor Renault, em versão inédita, atualizada pela Dagama Editora. Alguns procedimentos são claramente seguros e, alguns, a prudência recomenda que sua utilização seja acompanhada por técnicos das áreas afins. A exclusão dos procedimentos que utilizam produtos químicos, por exemplo, acarretaria em uma omissão de informações úteis, como a transformação de madeiras brancas de baixa qualidade, vendidas muitas vezes como lenha, em madeira de alta resistência com aplicabilidade em construções e de mais alto valor comercial.

As receitas selecionadas, apesar de não estarem divididas em capítulos como no livro, foram agrupadas de acordo com a semelhança de seus assuntos e dividemse em quatro grupos principais: nas primeiras receitas temos os métodos de preparação e conservação dos alimentos, coisas simples que a maioria das pessoas desconhece, como reconhecer a qualidade de um ovo ou como fazer presunto. A partir da receita ํo 30 entramos no campo da jardinagem e horticultura, área que, segundo Sir Burton, Victor Renault dominava tão bem. Da receita ํㅡ 58 "Colchões de musgo" até a ํo 83, que ensina mais um segredo para se apanhar ratos, são descritas e ensinadas atividades comuns no meio rural, como a criação do bicho da seda e da abelha. Nas receitas seguintes, entramos nas lições sobre vernizes e solventes, inclusive com os métodos para sua obtenção a partir de substâncias naturais. Naturalmente este assunto se transforma nos métodos de tratamento dos materiais de construção e de uso doméstico e assim se desenvolve até a última receita. Vale notar que esta não é uma divisão rígida, pois os assuntos se permeiam através das receitas.

É importante destacar que todos os termos utilizados nas receitas selecionadas são encontrados nos principais dicionários brasileiros, dispensando a necessidade de elaboração de um glossário. 


\title{
3.2 - Comparação entre as versões original (Typographia Garnier Irmãos, 1901) e atualizada (Dagama Editora, inédito)
}

\author{
Página fac-similar do livro THESOURO DAS FAMILIAS
}

\author{
CAPITULO XXXII \\ DOS MATERIAES PARA CONSTRUCÇÃO.
}

$1675^{\circ}$ Meio de conservar a madeira de construcção. - Dissolvem-se oito libras de sulfato de cobre, e molhe-se cinco a seis vezes com esta solução, por meio d'uma broxa ou d'um panno, a madeira caruncho e qualquer madeira branca afincada, durará tanto como a melhor madeira de lei.

1676 Madeira; receita para tornal-a incombustivel. - Dissolva-se terra silicosa em alcali caustico (Potassa caustica), e estenda-se este liquido sobre a madeira.

Depois pode-se lançâl-a no mais ardente brazeiro, porque o fogo não terá acção sobre ella.

1677 ${ }^{\circ}$ Modo de dar rijeza á madeira. - A madeira que depois de embebida de qualquer oleo ou

\section{Versão da Dagama Editora}

\section{CAPÍTULO XXXII}

\section{DOS MATERIAIS PARA CONSTRUÇÃO.}

$1675^{\circ}$ Meio de conservar a madeira de construção.

Dissolvem-se oito libras de sulfato de cobre, e molhe-se de cinco a seis vezes com esta solução, por meio duma broxa ou dum pano, a madeira depois de bem seca; ficará esta livre do cupim, do caruncho e, qualquer madeira branca afincada durará tanto como a melhor madeira de lei.

1676을adeira; receita para torná-la incombustível.

Dissolva-se terra silicosa em álcali cáustico (Potassa cáustica), e estenda-se este líquido sobre a madeira.

Depois pode-se lançá-la no mais ardente braseiro, porque o fogo não terá ação sobre ela.

$1677^{\circ}$ Modo de dar rijeza à madeira.

A madeira que depois de embebida de qualquer óleo ou matéria gordurenta, se conservar exposta por algum tempo a um calor moderado e depois de esfriar, fica muito luzidia e seca, e tem contraído às vezes tal rijeza, que corta e fura como uma arma de ferro. 
3.3 - Tabelas de conversão e equivalência de pesos, medidas e temperatura.

Fonte:Unidades de Medida - www.unificado.com.br/fisica/unidades.htm

3.3.1. - Tabela de conversão de temperatura

\begin{tabular}{|l|c|l|}
\hline \multicolumn{1}{|c|}{ De } & Para & \multicolumn{1}{|c|}{ Fórmula } \\
\hline Celsius & Fahrenheit & $\mathrm{F}=\mathrm{C} \times 1.8+32$ \\
\hline Celsius & Kelvin & $\mathrm{K}=\mathrm{C}+273.15$ \\
\hline Celsius & Rankine & $\mathrm{Ra}=\mathrm{C} \times 1.8+32+459.67$ \\
\hline Celsius & Réaumur & $\mathrm{R}=\mathrm{C} \times 0.8$ \\
\hline Fahrenheit & Celsius & $\mathrm{C}=(\mathrm{F}-32) / 1.8$ \\
\hline Kelvin & Celsius & $\mathrm{C}=\mathrm{K}-273.15$ \\
\hline Rankine & Celsius & $\mathrm{C}=(\mathrm{Ra}-32-459.67) / 1.8$ \\
\hline Réaumur & Celsius & $\mathrm{C}=\mathrm{R} \times 1.25$ \\
\hline
\end{tabular}


3.3.2- Capacidade - Equivalência

Medidas para Líquidos

\begin{tabular}{|l|r|r|}
\hline Medida & O mesmo que & Litros \\
\hline Tonel & 2 pipas & $\mathbf{8 4 7 , 5 0}$ \\
\hline Casco & - & 508,50 \\
\hline Pipa & 25 almudes & 423,75 \\
\hline Almude & 2 potes & 16,95 \\
\hline Pote & - & 8,47 \\
\hline Canada & 4 quartilhos & 1,41 \\
\hline Quartilho & - & 0,35 \\
\hline
\end{tabular}

Medidas para Secos

\begin{tabular}{|l|r|r|}
\hline Medida & O mesmo que & Litros \\
\hline Moio & 15 fangas & $\mathbf{8 2 8 , 0 0}$ \\
\hline Saco & & 82,80 \\
\hline Fanga & 4 alqueires & 55,20 \\
\hline Alqueire & $\mathbf{4}$ quartas & 13,80 \\
\hline Quarta & - & 3,45 \\
\hline Oitava & - & 1,72 \\
\hline Maquia & - & 0,86 \\
\hline Selamim & - & 0,43 \\
\hline
\end{tabular}


3.3.3. - Peso - Equivalência

\begin{tabular}{|l|c|}
\hline Medida & Quilos \\
\hline Tonelada (antiga) & 793,00 \\
\hline Quintal & 58,725 \\
\hline Arroba & 14,688 \\
\hline Arrátel & 0,459 \\
\hline Libra & 0,4536 \\
\hline Quarta & 0,11475 \\
\hline
\end{tabular}

\begin{tabular}{|l|c|}
\hline Medida & Gramas \\
\hline Arrátel & 459,0 \\
\hline Libra & 453,6 \\
\hline Quarta & 114,75 \\
\hline Onça & 28,6 \\
\hline Dracma & 17 \\
\hline Oitava & 3,585 \\
\hline Escrópulo & 1,195 \\
\hline Quilate & 0,199 \\
\hline Grão & 0,0497 \\
\hline
\end{tabular}


3.3.4 - Distância/comprimento - Equivalência

\begin{tabular}{|l|c|r|}
\hline Medida & O mesmo que & Metros \\
\hline Légua antiga & 3000 braças & 6600,00 \\
\hline Milha & 1000 passos & 1650,00 \\
\hline Canela & braças & 165,00 \\
\hline Braça terrestre & 2 varas & 2,20 \\
\hline Toesa & 6 pés & 1,98 \\
\hline Passo geométrico & 5 pés & 1,65 \\
\hline
\end{tabular}

\begin{tabular}{|l|c|c|}
\hline Medida & O mesmo que & Centímetros \\
\hline Vara & 5 Palmos & 110 \\
\hline Côvado & 3 palmos & 66 \\
\hline Pé & 12 polegadas & 33 \\
\hline Palmo & 8 polegadas & 22 \\
\hline Polegada & 12 linhas & 2,75 \\
\hline Linha & - & 0,29 \\
\hline Ponto & & 0,019 \\
\hline
\end{tabular}




\section{4 - AS RECEITAS, MÉTODOS, TÉCNICAS E PROCEDIMENTOS}

\subsubsection{Receita para limpar e refrescar a água.}

Num pipote novo, ponha-se, na altura de meio palmo acima da tampa debaixo, um segundo fundo crivado com pequenos buracos e cobertos com uma camada de palha. Em cima desta, deita-se areia limpa até encher o pipote pelo meio, acabando de enchê-lo com carvão. Deita-se, então, a água, a qual por muito suja que seja e por pior que seja o seu gosto, sai da torneira que se colocou por baixo da tampa furada, pura, limpa e fresca.

\subsubsection{Método abreviado, fácil e seguro de clarificar o açúcar.}

Faz-se dissolver 16 libras de potassa em 420 garrafas d'água, e mistura-se à dissolução, 1800 libras de açúcar bruto.

Quando o todo está bem incorporado, lançam-se-lhe 25 libras de barro de telha, misturado com bastante água, para lhe dar a consistência de um mingau ralo. Põe-se a ferver e quando estiver fervendo, mexe-se amiudadamente. De vez em quando, deixa-se parar a fervura, para tirar a escuma que é muito abundante.

Quando o açúcar está clarificado, deita-se em uma vasilha grande, que terá três torneiras colocadas a alguma distância uma das outras.

Cerca de doze horas depois de ter deitado o líquido, a calda do açúcar que fica da parte superior estando perfeitamente clara, é tirada por meio da torneira superior. À medida que a calda vai-se clarificando, é tirada pelas outras torneiras; sendo que para a última torneira, será preciso que a vasilha esteja um pouco acima do chão a fim dela esgotar bem.

Deve-se ter cuidado em não tirar o líquido quando ele começa a se turvar.

O líquido bem transparente é levado para as caldeiras, e ali se reduz em calda grossa para ir às formas.

\subsubsection{Refinação do açúcar.}

Depois de estar clarificado, ferve-se até ficar em ponto de calda. Tira-se depois o tacho do fogo e com uma grande colher, mexe-se violentamente em toda a circunferência até o centro do líquido; agitando-se sem interrupção, até que a medida que quer esfriar de todo se ache reduzido quase a pó e branquíssimo, o que depende: $1^{\circ}$ da boa clarificação, $2^{\circ}$ do ponto mais apropriado para esta operação e $3^{\circ}$ da agitação violenta, que se lhe deve dar enquanto quente e ainda 


\subsubsection{Propriedades dos ovos.}

A gema do ovo batida com um pouco de açúcar, dissolvida em água quente e bebida na ocasião de deitar, é boa as pessoas endefluxadas. E é o que se chama gemada.

A clara do ovo batida com água de tanchagem é boa para a inflamação nos olhos.

A pele aderente à casca do ovo, estando seca e moída, mista com a clara, é boa para os beiços rachados. A casca do ovo, queimada e reduzida a pó, é boa para alvejar os dentes. Serve ainda para fazer cessar os escarros de sangue sendo queimada, reduzida a pó e bebida com vinho.

Faz-se também um cimento muito bom para colar porcelanas quebradas, fazendo uma mistura de cal viva, cimento fino, casca de ovo (queimada e reduzida a pó) e betume. Estando tudo misturado, ajunta-se uma clara de ovo, que se mexe bem até formar uma massa homogênea.

\subsubsection{Meio de conservar ovos.}

Deitam-se os ovos frescos dentro de água quente, deixando-os dentro durante dois minutos, tirando-os e enxugando-os depois, para guardá-los em uma caixa, cobrindo-os com uma camada de areia bem seca.

\subsubsection{Ovos; método de conservá-los frescos por muito tempo.}

Escolhem-se os ovos postos em tempo fresco, nos meses de Março e Setembro.

Os desta estação conservam-se durante todo o inverno.

Os ovos não fecundados conservam-se mais tempo do que os outros. Conviria, portanto, separar os galos de algumas galinhas.

Não se devem depositar os ovos em adegas, porque se alteram e tomam mau gosto. A conservação do ovo depende principalmente da sua posição.

Cubra-se o fundo de um vaso ou de um cesto com uma polegada de cinzas. Ponham-se dentro os ovos com a ponta para cima. Cubram-se com outra camada de cinza, que exceda os ovos em uma polegada de altura. E continua-se do mesmo modo.

Deposita-se depois o vaso em lugar fresco e seco.

Também se conservam bem, metendo-os em leite da cal com greda. A matéria agarra-se à casca, tapa os poros e impede o contato do ar, que os corrompe. Guarda-se em lugar fresco. 


\subsubsection{Meio de conhecer ovos frescos.}

Dissolvem-se quatro onças de sal em uma garrafa d'água e deita-se o ovo nesta solução. Se o ovo vai ao fundo, foi posto naquele dia. Se nada no líquido, foi posto há 2 ou 3 dias e se finalmente, vem à superfície, é porque já foi posto há mais de cinco dias.

\subsubsection{Outro modo de conhecer os ovos frescos.}

Pondo-se o ovo na claridade ele apresenta-se transparente através da luz e chegando-se ao pé do fogo, cobre-se de um ligeiro suor.

\subsubsection{Modo de impedir que o leite se altere.}

Pode-se tornar o leite coalhado à sua fluidez natural, ajuntando-Ihe, enquanto quente, uma colher de leite ordinário, em que se desfaz uma pitada de carbonato de potassa ou bicarbonato.

Esta substância que é pouco dispendiosa e se encontra em qualquer farmácia, não comunica ao leite sabor desagradável.

É conveniente que se deite alguma quantidade desta substância no leite antes de o ferver, quando houver receio de que ele se altere ou azede, como muitas vezes acontece no verão, durante os grandes calores e especialmente no tempo da trovoada.

\subsubsection{Modo de conservar o leite por muito tempo.}

Deita-se o leite em garrafas bem tampadas, que se deixam estar 12 horas em banho-maria. O leite diminui alguma coisa e a água que contém evapora-se pela rolha.

Lacram-se as garrafas e pode, assim, servir para as grandes viagens marítimas.

\subsubsection{Modo de conservar o leite em pó.}

Dissolva-se uma oitava de bicarbonato de soda em uma onça de água. Ajuntese esta solução a 2 garrafas de leite e evapore-se no banho-maria até ficar reduzido à terça parte. Ajunte-se então, 1 libra de açúcar em pó e depois de se ter dissolvido, despeje-se o leite em travessas rasas, pondo este numa estufa ou no forno até secar. Reduza-se esta massa a pó e guarde-se em vidros bem tampados. Uma ou 2 colherinhas, numa xícara de água ou café, supre perfeitamente o leite.

\subsubsection{Modo de preparar a manteiga para conservá-la fresca por mui- tos anos.}

Tomam duas partes de sal de cozinha, uma de açúcar, outra de salitre. Pisa-se o todo e mistura-se bem. Uma onça desta mistura é para uma libra de manteiga, 
que se tritura até a perfeita incorporação das substâncias. A manteiga assim preparada, é posta em vasos de pó de pedra bem lavados e muito secos, havendo o cuidado de os tampar bem.

Não é indiferente a escolha do sal, do açúcar e do salitre próprios para a operação que indicamos.

Deve-se, primeiramente, purificar e secar o sal em forno. O açúcar deve também ser muito puro e seco. O salitre (nitrato de potássio) que muitos recearão empregar temendo acidentes, não oferece o menor perigo na dose que indicamos e só pode obrar como refrigerante. Mas é preciso procurá-lo muito puro.

Oito dias depois de guardada a manteiga nos vasos, vê-se que ela se contrai e que se forma um vácuo entre ela e as paredes do vaso. Prepara-se uma salmoura forte com sal refinado e água quente, quanto possa dissolver o sal e lança-se fria, pouco a pouco, sobre a manteiga, até que a cubra. Depois, depositam-se os vasos em lugar fresco.

Emprega-se água quente para preparar a salmoura, em razão da sua propriedade de dissolver maior quantidade de sal.

\subsubsection{Depuração dos óleos e manteigas.}

O processo seguinte é, sem dúvida, o melhor de todos os que tem sido publicados. Ajuntam-se 100 partes de óleo, 10 partes de água em que se tenha desfeito uma parte de farinha. Agita-se bem a mistura e depois aquece-se até que se evapore bem a água, ou antes, até que o óleo deixe de estar unido com as substâncias que tinha em suspensão.

Passadas vinte e quatro horas, ele sai claro e muito diferente em qualidade do que é preparado pelos melhores processos, perdendo assim toda a sua mucilagem.

Na prática deste processo deve haver o cuidado de aquecer o óleo gradualmente e de não elevar a temperatura acima de 80 graus de Reaumur.

Este calor é suficiente para operar a decocção da farinha e da substância mucosa-extrativa que contem o óleo. Um calor mais forte dar-Ihe-ia cor, tirando-Ihe a que é favorável para a venda.

Foi-se conduzido a este processo por uma observação que todos podem fazer. Sabe-se que um molho branco, estando muito cosido, separa-se em duas partes: uma que é espessa, ocupa o fundo da vasilha, a outra, que é clara, vem à superfície. A primeira substância é a parte caseosa da manteiga, que se une à farinha, junta ao molho e que se separa do óleo pela decocção. A segunda substância é a manteiga isenta de todos os princípios estranhos. 
Neste estado pode-se chamar manteiga purificada. $\mathrm{O}$ que se diz da manteiga é perfeitamente aplicável ao azeite e às banhas.

É a esta simples observação que veio a idéia de apurar os óleos com farinha e água, o que apresenta grandes vantagens.

Os óleos para a luz precisam de purificação para se tornarem mais próprios para a combustão.

A depuração destes óleos não é mais do que a sua clarificação depois de os ter privado da substância mucosa extrativa, que junta às substâncias heterogêneas que neles se acham misturadas, impedem que eles dêem uma luz pura.

Tem-se tratado dos meios de purificar os óleos, especialmente, depois que se introduziu na economia doméstica o uso dos candeeiros de dupla corrente de ar.

À 100 partes de óleo de colza segundo procede M' Tenard, ajunta-se uma parte de ácido sulfúrico do comércio, de 66 graus, diluído com 6 vezes o seu peso d'água, que se bate com força. Depois de feita a mistura íntima, deixa-se repousar até que o óleo esteja perfeitamente claro. Logo que está perfeitamente claro, está feita a sua depuração.

Há no fundo da vasilha um líquido ácido um pouco trigueiro.

Separa-se o ácido do depósito e, para ter a certeza de que o óleo não contém mais ácido, ajuntam-se algumas onças de greda ou de mármore branco em pó. Agita-se com força, deixa-se outra vez repousar o óleo e decanta-se.

O acido sulfúrico, ainda que modificado com água, é empregado para privar o óleo de toda a sua umidade e tirar-Ihe uma substância muscosa-extrativa, cuja presença no óleo diminui a energia da combustão, suja o pavio e produz muito fumo.

Portanto, as qualidades que estes óleos devem ter para alumiar bem, dependem da subtração destes princípios estranhos.

Terminaremos este processo por um outro, que pouco é empregado e que tem dado o melhor resultado.

Depura-se o óleo pelo mesmo processo que se emprega nas casas de famílias para preparar a manteiga derretida e que consiste em fazê-la ferver a fogo brando, ajuntando-Ihe cebolas inteiras por 100 libras.

Sustenta-se a ebulição por três horas, sem escumar. Tira-se depois a caldeira do lume e deixa-se repousar por uma hora.

Sujeitando o óleo à mesma operação, faz-se claro e basta então lançar em uma libra, pouco a pouco, meio copo de água fria. Agitar bem e repousar, até que as impurezas que não subiram à superfície, tenham tempo de se depositar no fundo. 
Depois de suficiente repouso, tira-se a escuma e decanta-se o óleo, escorrendo-o, com cuidado para não levantar o depósito de que ainda se tira proveito, passando-o por uma peneira ou pano delgado.

O óleo que vem fica à superfície e tira-se com uma colher.

Depois desta preparação, o óleo fica excelente e não torna a carbonizar-se.

\subsubsection{Peixe; processo para conservar fresco por muito tempo.}

Rale-se suficiente porção de miolo de pão e deite-se em espírito de vinho na quantidade suficiente para ficar como papas. Enche-se com esta massa a boca e as guelras do peixe e envolve-se, depois, em uma camada de urtigas frescas e numa outra de palhas, que se deverá borrifar com água de duas em duas horas.

Deste modo, conserva-se o peixe, por dias, mesmo no verão, tão fresco como se fosse apanhado de pouco tempo.

Este meio é de muita vantagem para mandar peixe fora do país, ou para presente em sítio muito distante.

\subsubsection{Meios de conservar e de salgar os peixes.}

Os métodos que se tem achado e estão escritos para conservar as substâncias animais em seu estado fresco e por tempos, são todos deduzidos das fórmulas inventadas para se obter a conservação dos frutos e outras espécies vegetais.

Sendo, porém, estas, de natureza inteiramente diversa e que mais facilmente se conservam em bom estado por muito tempo, não sucede o mesmo às substâncias animais, quando os mesmos meios se aplicam para as preservar das alterações que lhes são próprias.

Três meios temos para conservar o peixe em estado perfeito. E isto, mesmo, por pouco tempo.

O primeiro, para quando se queira transportá-lo a cem e mais léguas, é metêlo, logo que se pesca, em barris cheios de água salgada, tendo-se o cuidado em que a água o cubra bem e que os barris sejam hermeticamente fechados.

Neste estado pode conservar-se 6 ou 8 dias, conforme a temperatura da atmosfera.

O segundo meio consiste em tomar o peixe o mais fresco que for possível, tirar-lhe as escamas e as entranhas e, sem o partir nem lavar, envolvê-lo bem com sal miúdo e deixá-lo assim por 4 ou 5 horas.

Neste intervalo levam-se ao fogo partes iguais de água e de bom vinagre bran- 
co de vinho, com alguns bagos de pimenta e de cravo da Índia, tudo inteiro e com algum aipo ou salsa.

Corta-se então o peixe em postas, se o seu tamanho o permite e lava-se bem para o introduzir no líquido fervendo, onde se não deve demorar mais do que três ou quatro fervuras, conforme a sua consistência.

Retira-se então do fogo e, depois de frio, tira-se o mesmo peixe com uma escumadeira e vai-se acomodando bem em pequenos barris.

Quando estes se acham cheios, deita-se-lhes até estarem bem atestados, a calda fria e coada em que se ferveu o peixe, a fim de não levar substância alguma das que entraram na sua composição.

Se é para se transportar para longas distâncias, envernizam-se os barris. Este meio de conservar o peixe em estado fresco é bom, porque assim não fica cozido e pode-se, depois, prepará-lo como aquele que é recentemente pescado. A experiência, porém, mostra não ser este mesmo método suficiente para assim o conservar além de 30 dias. Mas também não se conhece outro melhor.

A maneira de salgar o peixe requer algumas considerações.

A primeira é que o sal seja fabricado em costas de mar, onde a água salgada é mais pura e onde não é preciso estagná-la para a primeira cristalização, que é a mais perfeita em suas qualidades físicas e a única capaz de segurar, em estado são, as substâncias animais sem perderem o sabor, nem adquirirem facilmente o ranço que Ihes provém de todos os princípios alimentícios e as torna, assim, danosas à saúde. O que aconteceria com o sal grosso tirado dos rios de água salgada onde se misturam ribeiros de águas doces e barrentas. A cristalização deste sal e o seu sabor mais amargo do que salgado mostram claramente que contém mais sulfato de soda do que muriato de soda ou sal marinho puro, que é de um sabor salgado agradável, forte e sem amargo algum e deixa no paladar um gosto que serve de comparação para o distinguir de todas as espécies dos sais marinhos impuros.

Para se fazerem boas salgas de peixes, se são corpulentos, corta-se em retaIhos maiores ou menores, sem Ihes tirar as escamas nem os lavar. Salga-se sobre estrados de madeira com bom sal miúdo para, ali, se esgotar toda a umidade, durante três ou quatro dias. Embarrica-se com novo sal, calcando-os bem para que as postas fiquem muito unidas e, os barris, o mais cheios que for possível. Tapa-se finalmente com a maior exatidão. Os peixes que se salgam para depois se secarem, assim como o bacalhau, as pescadas, as corvinas e outros mais, são primeiramente abertos em todo o seu comprimento e tiram-lhes as entranhas, a cabeça e a espinha grossa, mas nunca a escama e nem também se lavam. Corre-se sobre 
estrados de tábuas ou sobre os conveses dos mesmos barcos de pesca, cobrem-se com uma delgada coberta de bom sal miúdo escolhido como temos recomendado.

Salpicam-se levemente os peixes e vão-se estendendo sobre o lastro de sal com a parte da escama virada para baixo. Estando assim pronta a primeira camada de peixe, salpica-se com sal por toda a superfície superior e põe-se sobre esta outra camada com as mesmas formalidades, até que todo o peixe esteja empilhado. Carrega-se então a pilha com um grande peso, para lhe extrair a umidade e para estendêlo a fim de melhor secar.

As embarcações que nos mares do norte fazem estas pescarias, trazem a bordo os utensílios precisos para facilmente armarem espécies de imprensas que produzem este efeito de compressão com maior rapidez e economia. Passados dois dias, pendura-se o peixe ao ar livre por 24 horas e torna-se a empilhar, aplicando-Ihe ainda a mesma pressão por mais 24 ou 30 horas. Pendura-se outra vez ao ar até estar o mais seco possível, porque é este o melhor estado para a sua duração e boa qualidade. Se o sal é bom, o peixe assim preparado fica sendo um alimento saudável. Para salgar as sardinhas, anchovas e outros peixes que são também objetos de comércio, há um excelente meio que não só impede que se alterem, mas até dispensa de serem remolhadas antes de se comerem. Acresce que duram muito mais tempo perfeitos do que sendo salgados e guardando o sal.

Tomam-se, pois, as sardinhas bem frescas no mês de Novembro e Dezembro, escamam-se somente no lombo tirando-lhes as tripas e barbelas e salgam com sal bem miúdo sobre esteiras para escorrer a umidade. Decorridas 36 até 40 horas, passam-se por água, para Ihes tirar todo o sal, tornam-se a deitar sobre redes ou esteiras, para ali expostas ao ar perderem a umidade da lavagem, até estarem bem enxutas e secas. Embarricam-se pela forma seguinte: estende-se no fundo do barril uma ligeira camada de sumidades de orégãos. Tomam-se as sardinhas, metendose as costas de umas dentro da cavidade das barrigas das outras, para assim as unir bem e, acamando no barril, de modo que entre cada duas camadas de sardinhas se deite uma de orégãos. Calcando-as, quanto puder ser, para Ihes não ficar muito ar dentro.

Depois do barril estar bem cheio com cogulo, põe-se-Ihe o tampo, carregandose este com um peso, até que pelo abatimento do cogulo se possa pôr fundo, de maneira que o peixe fique bem comprimido entre os dois fundos.

\subsubsection{Modo de conservar carne fresca.}

Salga-se a carne unicamente com o sal necessário para o seu tempero, e guarda-se cortada em postas que se envolvem em pó de carvão, no barril que se acaba do cobrir do mesmo pó. 


\subsubsection{Modo de conservar carne.}

A melhor mistura para salgar carne é a seguinte: sal: 4 libras, nitro: meia onça, açúcar: seis onças. Tudo moído e bem preparado. Esta mistura da à carne um gosto agradável e faz que cozinhe melhor do que sendo guardada com sal só.

\subsubsection{Presuntos, sua preparação.}

Como os bons presuntos são muito estimados e dão lugar a um considerável ramo de comércio parece-nos útil tratar de sua preparação. Os presuntos da Inglaterra que não são curados pelo velho método, têm mais partidários entre as pessoas que não estão acostumadas à carne curada ao fumo, do que os presuntos curados, como é costume em outros paises. A preparação inglesa faz-se pelo modo seguinte: toma-se 1 libra de açúcar mascavo para 9 pratos de sal e 2 onças de salitre. Soca-se bem o sal. Depois, pisa-se com o açúcar e o salitre, até que se reduza tudo a pó fino. Esfregam-se com força os presuntos e deixam estar durante 20 dias na salmoura, tendo-se o cuidado de cobri-los bem com ela. Depois, suspendem-se ao ar até que sequem. Esta quantidade de salmoura quase que basta para salgar três presuntos; os pequenos só carecem de 15 dias na salgadeira.

Na Westphalia, cujos presuntos formam um ramo de comércio tão importante, são esfregados com sal e, em seguida, são comprimidos em barricas de maneira tal, que a salmoura a custo as penetra. Passados 15 dias tiram-se da salmoura e penduram-se em uma chaminé, onde se queima ordinariamente faia, mas a tal altura que não lhe possa chegar o fumo quente. No fim de 20 dias são levados para lugar seco. As chaminés dos aldeãos de Westphalia não se abrem pelo cume, como acontece em quase todas as outras partes, mas por trás, ou sobre o lado da casa. A sua altura pouco excede a dos tetos. O fumo espalha-se ali por toda a casa, mas a experiência tem ensinado que os presuntos que estão expostos a este fumo, não são tão bons como os que se curam ao fumo nas chaminés das cidades que tem mais altura. Ainda há outro método de preparar os presuntos.

O toucinho esfregado com sal pisado e quente é posto sobre uma mesa durante 24 horas. Depois, tiram-Ihe todo o sangue e sal com um pano molhado e mete-se na salmoura seguinte: tomam-se para 4 arrobas de toucinho, duas libras de açúcar mascavo em pó, 8 libras de sal e 1 libra de salitre pisado. Lançam-se sobre ele 12 garrafas d'água aquecida até a ebulição. Mistura-se bem, durante este tempo, a salmoura. Escuma-se e, depois de fria, passa-se por peneira. $O$ toucinho é depois metido em uma barrica e lança-se sobre cada camada, uma mistura de três dentes de cravo da Índia, igual quantidade de pimenta, 10 grãos das quatro espécies, tudo pisado. Também se deita salmoura em cada camada. $O$ toucinho é virado de três em três 
dias na barrica e, no fim de 16 dias, é tirado para ser pendurado em lugar onde esteja exposto à ação de um fumo frio. É preferível o de lenha de carvalho. Se o fumo for continuo, basta que a carne esteja exposta a ele 10 ou 12 dias.

O gosto dos presuntos assim preparados excede talvez aos da Westphalia.

\subsubsection{Presunto de fiambre.}

Depois de bem limpo e aparado um presunto de tamanho regular, deite-se de molho por 2 ou 3 dias, renovando-Ihe a água. Coze-se em quantidade suficiente d'água que cubra bem todo o presunto e, em estando meio cozido, deitam-lhe duas garrafas de bom vinho branco e acaba-se de cozer neste vinho. Deve-se ter deitado, salsa, tomilho, manjericão, cerefólio, pimenta e cravo inteiro. Depois de cosido o presunto, deixa-se ficar na calda um pouco, tira-se, escorre-se e tira-se-lhe a pele. Passa-se por miolo de pão ralado fino e põe-se no forno a corar, até que adquira uma cor e um tostado agradável. Envolve-se então a extremidade da perna de papéis bordados e fitinhas de cor e manda-se para a mesa.

\subsubsection{Outra preparação dos presuntos.}

Tomam-se meia libra de açúcar bruto, quatro pratos e meio de sal e quatro onças de salitre.

Faz-se secar bem o sal em uma frigideira. Depois, soca-se o salitre e o açúcar, até que tudo esteja reduzido à pó fino. Depois, furam-se os presuntos em diversos lugares e, dentro destes, se introduz um pouco deste pó, com o qual também se envolvem os presuntos que em seguida vão para uma salmoura, onde devem ficar cobertos e permanecerem durante 20 dias. Findos os quais, vão para a fumaça.

\subsubsection{Carne de fumaça ou de Hamburgo}

Escolham-se boas postas de carne de vaca bem gorda e preparam-se como o presunto. Em 48 horas se pode alcançar este fim. Dissolve-se em água tanto de salitre, sal e açúcar quanto for necessário para uma salga ordinária. Ajuntando-se nesta 40 gotas de querosene, expõe-se, por algumas horas, a lume brando, a peça de carne a cozer, até a água se evaporar de todo. Pendura-se depois por espaço de 24 horas, exposta a um fumo forte e fica logo tão rija e tão vermelha por dentro como as que vem secas do Norte.

\subsubsection{Modo de fazer carne seca à Mineira.}

Retalha-se a carne em mantas mui delgadas que se salgam bem e se penduram em varais exposta ao sol e sereno por dois ou três dias. 


\subsubsection{Conservação da carne curada.}

Para conservar-se por muito tempo a carne curada, presuntos, toucinho, etc., encaixota-se com resíduos secos de cevada, que se encontram em qualquer fabrica de cerveja. Por este modo é que os Ingleses conseguem transportar para longas distâncias as suas provisões em muito bom estado.

\subsubsection{Salmoura para a conservação da carne.}

Deitem-se em um tacho, 24 garrafas d'água, uma libra de sal, meia libra de açúcar e duas onças de nitro. Ferve-se, tira-se a escuma e despeja-se quente sobre a carne e as línguas que se querem conservar, deixando-se neste líquido até a hora de se empregarem.

\subsubsection{Conservação das carnes em estado fresco ou salgado.}

As carnes quaisquer que sejam não se podem guardar frescas por muitos dias e ainda assim é preciso dar-lhes algumas fervuras.

Todavia a carne de porco conserva-se por muito mais tempo, assando-se levemente e guardando-se metida em banha que não tenha umidade alguma. Também se conserva em vinagre ou vinho branco, sem que seja necessário ir primeiro ao fogo. Estes dois métodos servem igualmente para conservar as peças de caça, tais como perdizes, galinholas e outras aves. As carnes destinadas para salgar devem ser ainda mais bem sangradas do que as destinadas para se gastarem frescas. Escolhe-se bom sal, e embarrilam-se logo. Este método é para as conservar na própria salmoura. Porém, bem salgadas e deixando-Ihes escorrer todo o líquido por 2 dias, esfregandoas depois bem com sal miúdo e embarrilando-as logo, ainda são preferíveis, porque assim vão já livres das substâncias que as dispõem para a sua alteração.

\subsubsection{Método de conservar os frutos sem alteração alguma por mais de um ano.}

Para a conservação das uvas, o melhor e o mais seguro método, essencialmente se se destinam para transportar a outros países, é o seguinte.

Logo que esta fruta está quase madura, tomam-se folhas de papel e enrolam-se, colando-se duas margens com goma ordinária, para formar uns perfeitos cilindros.

Introduzem-se os cachos, estando ainda nas plantas, cada um em seu cilindro, que se faz superiormente sobre os pés dos cachos, dando-lhes um nó bem apertado de delgado fio de barbante e deixando-se uma aselha para se pendurarem. Mas tudo isto deve ser feito sem magoar os bagos. Atam-se depois, também da mesma forma, as extremidades inferiores dos cilindros com toda a exatidão precisa para lhes evitar o menor ar. 
Cortam-se então os pés três ou quatro linhas acima dos nós e mergulha-se, sem demora, o corte em uma mistura de partes iguais de pez e de cera, derretidos e bem quentes. Penduram-se, finalmente, em lugar onde não recebam sol nem muita luz.

As uvas assim preparadas duram em seu perfeito estado viçoso mais de um ano.

É desta mesma forma que se devem acondicionar para se transportarem. Metidas em caixas e envolvidas em palha delgada de milho ou em sêmea, bem expurgada, da farinha; para que se não magoem, pois que, a menor quantidade de suco que vertam, promove a fermentação vinhosa e perdem irremediavelmente um cacho de frutas.

Deve também haver a maior cautela no encaixotar estes frutos. Essencialmente, se vão para países mui distantes. Que as caixas sejam bem abetumadas, com qualquer betume ordinário, nas juntas da madeira. Para que nem a umidade as penetre, nem o ar tenha grande comunicação com os frutos.

\subsubsection{Para conservar os frutos de pevide em seu perfeito estado de madureza por mais de um ano.}

Todos os pomos, tais como, romãs, maçãs, marmelos e pêras, devem ser colhidos no $7^{\circ}$ ou $8^{\circ}$ dia da sua madureza e às horas em que o sol esteja bem quente.

Escolhem-se sempre os mais bem nutridos, e sem mácula alguma, e estendem-se em bancas unidas, sobre uma camada de palha fina de milho, tomando-se o cuidado de não os ter muito unidos uns aos outros.

Deixam-se expostos à luz e ao ar por 8 dias e, passado este tempo, fecham-se as portas e janelas da casa em que estiverem, para livrá-los, quanto for possível, da luz e de grande corrente de ar.

Visitam-se os frutos de dias a dias para separar-se algum que se tenha alterado, evitando sempre a luz, quanto poder ser, durante os 3 ou 4 primeiros meses. Deste tempo em diante já não sofrem alteração alguma, expostos a todo o tempo.

Os melões e outros frutos semelhantes, conservam-se pendurados em redes de cordel, ou melhor ainda, de palha de tábua, ou outra qualquer, separados uns dos outros 3 ou 4 polegadas.

Para que estes frutos durem muito tempo, é preciso que a sua colheita se faça, quando muito, no fim da quadra de sua frutificação. Escolhem-se, não os maiores, mas os de mediana grandeza, que não estejam pisados e, se ainda for possível, com o cotão áspero que todas as espécies de melões de boa qualidade conservam até sua completa madureza.

Astier de Toulouse diz que a curta duração e ruína dos frutos sucosos são 
sempre devidas à extravasão da seiva (humor conservador e nutriente de todos os vegetais e seus produtos), a qual se transpira pelo corte praticado para os colher da planta madre. E que, evitada logo esta efusão, pode-se conservar em seu perfeito estado e frescos, pelo tempo de três novidades.

Neste processo pouco se tem que fazer.

Quando se quer colher os melões e outros frutos para guardar, prepara-se primeiro um betume de partes iguais de cera e pez, com suficiente quantidade de pó fino de tijolo para o encorpar.

Cortam-se os frutos na árvore, deixando-lhes só meia polegada de pé, que se mete no betume derretido e bem quente, tendo o cuidado de tapar bem a extremidade cortada. Isto deve-se fazer rapidamente, à medida que se vão colhendo os mesmos frutos, sem os pisar nem esfregar. Depois, penduram-se como já ensinamos.

Diz o mesmo autor, que os conservou por este modo por três anos.

\subsubsection{Método de preparar os frutos para se transportarem.}

Escolhem-se os frutos bem nutridos e bem sãos, no princípio da sua madureza e às horas de bom sol, sem, de forma alguma, os magoar. Metem-se em barris bem concertados, sem, contudo, os oprimir.

Cada fruto, de per si, deve ser bem embrulhado em papel aluminado (passado por uma forte solução de pedra-ume e bem seco depois) e os barris devem ser bem corridos, por todas as juntas, com betume de pó de tijolo bem quente.

Tampam-se, depois, exatamente e abetumam-se os tampos.

Metem-se estes barris dentro de outros maiores, de sorte que fique entre eles um intervalo de duas polegadas ao menos e introduzem-se, circularmente, algumas cunhas de pau, para os fazer fixos. Para que o barril interno fique bem seguro e bem no centro do barril externo.

Enchem-se depois d'água os intervalos intermediários, tapa-se o barril externo e abetumam-se as juntas do tempo.

Assim se transportam também os frutos de todas as regiões Asiáticas e Americanas para a Europa.

Há ainda outro método para acondicionar os frutos que se querem transportar para aquelas regiões. Toma-se uma parte de salitre em pó, 2 partes de bolo-armênio em pó e 4 partes de areia branca bem fina. Mistura-se tudo o mais exatamente que for possível.

Colhem-se os frutos sem lhes tirar o resto do pé que Ihes fica agarrado, nem os esfregar de sorte alguma. Metem-se simetricamente em vasos grandes de barro 
que tenham a boca bem larga. Fecham-se depois os vasos com pedaços de pano de algodão oleado e seguram-se com cordéis bem atados nas bordas das bocas dos mesmos vasos.

Metem-se então cada um destes vasos em seu caixote que deve ter no fundo um lastro ou camada de 3 polegadas de espessura da composição acima dita. Enche-se todo o resto dos caixotes, pelos quatro lados e pelo lado da tampa, com a mesma composição.

Tampam-se depois e abetumam-se as juntas do caixote.

Tendo M. Astier de Toulouse observado muitas vezes que se previne inteiramente a fermentação do mosto das uvas passando por ele uma corrente de gás sulfuroso, mergulhou neste líquido várias espécies de frutos, tais como ameixas, pêras, maçãs, e marmelos.

Depois de impregnar bem o mosto com este gás (ácido sulfuroso), guardou nele, para a experiência, uma boa porção destes frutos durante dois anos. No fim deste tempo, os achou ainda tão sãos como se fossem apanhados naqueles mesmos dias.

\subsubsection{Conservação das frutas no estado de frescas por meio da guta- percha.}

Quando se dissolve a guta-percha no sulfato de carbono, o líquido se separa em 3 camadas. A camada superior encerra matérias mucilaginosas, a inferior contém matérias ervosas e outras impurezas. Quanto à camada do meio, esta é perfeitamente límpida e encerra o princípio mais puro da guta-percha.

É com o líquido desta camada do meio, que se separa com o sifão, que se poderão conservar os frutos verdes no estado de frescos.

Para este fim, colhem-se os frutos antes de sua maduração completa. MerguIham-se os frutos no espírito de vinho e, em seguida, por diferentes vezes, no líquido de guta-percha, proveniente da camada do meio, que se acaba de mencionar. Pode-se depois guardar os frutos em caixas, armários, cujo calor não exceda a $10^{\circ}$ centígrados.

Para comer-se o fruto, assim coberto desta leve camada de guta percha, tirase com uma faca, lava-se a superfície com um pouco de álcool e encontra-se uma fruta que, apesar do tempo e das viagens, conserva seu perfume e seu sabor, como no estado de fresca.

\subsubsection{Da mergulhia e alporques.}

Muitas árvores e arbustos se multiplicam mais facilmente por mergulho e alporque da maneira seguinte: Abaixa-se um ramo que se fende de baixo para cima no lugar 
em que deve ficar enterrado; alguns o retorcem ou fazem-Ihe um entalhe; quando os ramos não se querem dobrar facilmente, obrigam-se com estacas fincadas na terra, que os sujeitem, ou então se Ihes aplica um barril ou cortiço cheio de terra boa e cobre-se com musgo, e rega-se até criarem raízes, em termos de se poderem separar e transplantar. Outros apertam um arame em torno do ramo em que se quer fazer o alporque e pela parte de cima do arame fazem com uma verruma diversos furos na casca. Outros fazem um golpe de baixo para cima, na parte em que se acham um nó, e a que chamam língua, como nos craveiros. Outros finalmente cortam em círculo, da largura de meia polegada de largo, a casca que há de vir a ser coberta de terra.

\subsubsection{Enxerto Chinês.}

Os Chineses em lugar de propagarem as árvores frutíferas por meio da semente ou enxertia imaginavam outro meio, publicado depois em Inglaterra pelo Doutor James, o qual é o seguinte: escolhem a árvore que desejam propagar, tomam o ramo, que depois de cortado a desfeie menos, e em roda dele, e o mais perto possível do tronco, que sem opressão se possa operar, enrolam uma corda de palha coberta de bosta e dão-Ihe tantas voltas quantas sejam precisas para que a rodilha forme cinco ou seis vezes o diâmetro do ramo; é no centro desta rodilha que se tem do formar as raízes.

Feita esta operação, cortam a casca até o linho imediatamente abaixo da rodilha, na proporção unicamente de dois terços, pouco mais ou menos, de casca do ramo em circunferência: penduram depois em um ramo superior ao operado e acima do centro da rodilha, uma casca de coco, ou qualquer vaso, com um pequenino furo no fundo, a fim de que não deixe cair a água, de que deve estar logo cheio, senão gota por gota.

Durante três semanas nada mais se the faz do que entreter o vaso sempre cheio de água; e findo este tempo, corta-se o terço restante desta casca e profundase a primeira incisão muito pelo lenho; nesse tempo, já algumas raízes se terão formado. Passadas outras três semanas, repete-se a mesma operação; em geral, dois meses depois do princípio desta tentativa vêem-se as raízes entrelaçarem-se na superfície da rodilha que é o anúncio de ter chegado o tempo de se separar o ramo do tronco; o que se fará por meio de um serrote de dentes finos ou serra própria, e no lugar da incisão, a fim de abalar o menos possível a rodilha, porque então a corda acha-se já podre: isto feito, planta-se o ramo como uma árvore nova.

As vantagens deste método são que sendo os ramos plantados assim, fortes, ao cabo de três para quatro anos, estarão as novas árvores dando fruto, quando as mesmas árvores no mesmo clima, vindas de semente gastam oito a dez anos, antes que frutifiquem. 
Os indígenas desfolham as árvores tardias em frutificar, porque deste modo os sucos nutritivos são mudados ou virados, fazendo aparecer flores em maior abundãncia.

\subsubsection{Enxerto de coroa.}

Faz-se no princípio de outubro.

Cortam-se os ramos horizontalmente e se lhes põe três ou quatro garfos, que são aparados na base de um só lado, e se introduzem entre a casca e a madeira duas polegadas, com o encaixe aparado para dentro e se cobre tudo com barro, não deixando de fora mais que dois botões.

\subsubsection{Enxerto de fenda ou garfo.}

Faz-se em agosto e setembro.

Corta-se a haste obliqua ou horizontalmente, e se racha exatamente pelo meio até duas polegadas: insinua-se-lhe no meio um ponteiro ou cunha para ter a fenda aberta, a fim de se lhe meterem os dois garfos, que devem estar aparados na base de um e outro lado, a modo de cunha, e ajustarem exatamente com a casca do cavalo; depois tira-se-Ihe a cunha do meio e liga-se com junco, vime ou fio de lã, e cobre-se de barro ou de terra, se é feito embaixo na raiz. É preciso ter cuidado de não tocar a cunha com os dedos quando se a faz.

\subsubsection{Enxerto de escudo ou de borbulha.}

É ordinariamente usado desde dezembro até fevereiro para as frutas de caroço, principalmente pêssego, damascos, cerejas, ameixas; assim como também nas laranjeiras e outros arbustos de espinho.

Depois de se ter escolhido sobre a haste que deve ser enxertada, um lugar liso, acima da terra três pés, pouco mais ou menos, com um canivete se faz na casca (de modo que não fira o pau) uma incisão atravessada e outra perpendicular que tenha a figura de um - T - tendo a perpendicular duas polegadas.

Depois se prepara o botão da qualidade que se quer e do modo seguinte: corta-se a folha que o acompanha, deixando-Ihe o pedúnculo; dá-se-Ihe um corte atravessado por cima, e dois pelos lados em forma de triângulo ou escudo em figura de um V, ficando o botão no meio, e se extrai, de modo que o botão venha apegado.

Depois levanta-se com jeito a incisão a modo de $\mathrm{T}$, e se insinua o escudo exatamente entre o pau e a casca, ficando o botão a vista e o lado de cima bem unido ao corte de cima que forma a cabeça do T; porque neste lugar é que se solda o enxerto, o que contribui para o bom êxito. 
Logo se junta a incisão com junco ou fio, principalmente por baixo, para não ofender o botão: e será bom untar a incisão com cera ou greda, não cobrindo o botão. Daí a um mês deve desligar-se, aparar-lhe os ladrões e cortar-lhe a haste três polegadas acima do enxerto obliquamente.

Alguns enxertos pegam sem que arrebentem naquele ano, e chamam-lhe de gomo dormente.

\subsubsection{Enxerto de approche.}

Faz-se em outubro um entalhe de duas polegadas no galho que há de servir de garfo, debaixo para cima em forma de lingüeta ou cunha; e no cavalo se faz um igual corte de cima para baixo, para receber a lingüeta; depois se unem de modo que as suas cascas sejam perfeitamente juntas e em contato; ligam-se e se cobrem com barro, para os livrar do contacto do ar e da umidade; depois seguram-se bem a uma estaca e cobre-se com barro a incisão feita obliquamente quando se deu o corte.

Usa-se sobre as nogueiras, figueiras, amoreiras, laranjeiras, etc.

\subsubsection{Regras gerais a seguir nos enxertos.}

Todas as árvores de mesmo gênero, isto é, que concordam em suas flores e frutos pegam bem umas sobre as outras, ainda que não tenham semelhança nas suas folhas - assim o loureiro e a cereja pegam entre si; e as que produzem landes ou bolotas, da mesma maneira. Para cobrir as fendas dos enxertos, usam muito, em lugar de barro simples, de uma massa composta de greda, excremento de cavalo, alguma palha bem moída e umas pedras de sal, amassado tudo bem com água.

Ainda impede melhor a passagem do ar a seguinte composição: terebintina, cera e resina; ferve-se tudo e aplica-se pouco quente sobre o enxerto; e quando vêm os calores fortes, cai esta composição sem fazer dano.

A uma libra de terebintina pode ajuntar-se meia libra de cera e pez; é excelente vulnerário para as plantas. A cera da terra simples supre bem todas estas composições.

\subsubsection{Reproduzir as árvores por meio de estacas empregando o colódio.}

Este processo consiste unicamente em cortar o galho de uma árvore ou qualquer planta, untar de colódio o lugar cortado ou esgalhado; esta substância preserva a planta da umidade em excesso, assim como da ação do ar, e torna certo o resultado muito mais pronto e mais fácil.

Também se usa do colódio nos enxertos, em lugar de resinas, ceras, terebintinas, etc.; usa-se para impedir a ação do ar sobre as plantas cortadas. 


\subsubsection{Reprodução das plantas por meio do carbono.}

Põe-se carvão em pó em uma solução leve de goma arábica de maneira a formar uma massa compacta; põe-se nesta massa as extremidades inferiores das mudas, galhos, ou estacas, e deixa-se secar um pouco a massa que adere; plantase depois a muda numa terra arenosa ou mesmo em areia; por este processo não falha de pegar qualquer muda de planta.

\subsubsection{Estrume para árvores frutíferas.}

Longas experiências mostraram que o sal de cozinha é o melhor estrume para árvores frutíferas. Semeando-se em roda da árvore um prato de sal, misturando-se este com um pouco de terra cavada; colher-se-ão 3 vezes mais frutos que do costume.

Tem-se ultimamente feito observações importantes sobre a frutificação das árvores; e tem-se conhecido que a sua esterilidade era, entre muitas outras causas, devida à presença de um inseto microscópico a que os naturalistas dão o nome de Oïdium1; é este inseto que amofina as plantas e que acomete sobretudo as parreiras, figueiras, etc; e neste caso, o sal recomendado não é suficiente nem para afugentá-los nem para matá-los; porém, uma libra de caparrosa (sulfato de ferro) posta na raiz da árvore, fá-los-á desaparecer para sempre.

\subsubsection{Observações importantes acerca da poda das árvores frutíferas.}

Há uma proporção recíproca entre os galhos que se prestam incessantemente a um concurso mútuo; de maneira que intimamente unidos de interesses, uns sofrem da supressão dos outros. Quando se cortam demais os grossos galhos de uma árvore robusta, as raízes, cuja ação não pára, desenvolvem o aparecimento de uma multidão de galhinhas que nada produzem, e neste estado as raízes sofrem e a árvore fenece.

É, pois, indispensável poupar os ramos vigorosos, para manter a concordância direta entre os galhos e as raízes.

Uma árvore muito vigorosa de um lado prova que a seiva tem um motivo poderoso para ali abundar; reprimindo-se a impetuosidade dos ramos muito fortes, o equilíbrio restabelece.

Como a seiva tem tanto mais ação quanto ela se precipita do centro; para mantê-la nesta posição é mister fazer sofrer à árvore uma poda mais moderada.

É preciso podar mais rente o lado mais abundante de folhas.

Aquele que pelo contrario, não aproveita, deve ser desembaraçado de todos os seus galhos preguiçosos, para dar ocasião à seiva, e obrigá-la a mudar sua direção nimiamente abundante. 
Pode-se, sem perigo, desguarnecer um galho nimiamente guarnecido de foIhas; porque neste caso elas devoram com demasiada pressa o alimento da árvore, e a fazem fenecer.

Alem destas observações, é preciso atender a outras importantes a fim de alcançar sempre frutos de uma árvore; sabe-se que numa árvore há três qualidades de galhos: os parasitas, os gozos, e os frutíferos; os parasitas ou galhos gulosos são aqueles que absorvem toda a seiva da árvore em prejuízo dos mais galhos, que fenecem e não dão frutos em tempo algum; é, pois, preciso cortá-los sem compaixão; estes se distinguem pelo seu grande viço, e o galho é de uma cor mais esverdeada do que os outros, que tem uma cor pardacenta.

Os galhos gozos "chifones" ou galhos gorados são os que não dão frutos e quase não dão folhas, e que se reconhecem pelo seu aspecto doentio, estes devem ser desapiedadamente cortados; e se se não o fizer, a natureza se incumbirá no ano seguinte de o fazer, visto que aparecerão secos, porém é muito conveniente que sejam cortados para não absorverem inutilmente a seiva.

Finalmente restam os galhos frutíferos, que se conhecem pelo vigor que apresentam, os botões que aparecem em toda a sua extensão e um certo vidro que cobre a sua casca; além destas considerações, é preciso, quando na ponta de um galho frutífero há muitos ramilhos frutíferos, é preciso, digo, calcular a força vegetativa destes galhos e deixar somente tantos ramilhos frutíferos quantos se julgar a árvore capaz de comportar; assim se pratica na poda da parreira, laranjeira, figueira, etc.

As podas sempre devem ser feitas depois que a árvore tiver dado os seus frutos e antes que se tenham desenvolvido os botões frutíferos.

Algumas vezes um galho mostra muito mais vida do que os outros mais gaIhos; para atrasá-lo a fim de que não absorva só a seiva da árvore, dever-se-á aparar a ponta com o podão ou simplesmente tirar com a unha aponta do galho conforme o desenvolvimento.

Finalmente, há galhos que se cortam, embora sejam frutíferos, porque incomodam ou tiram todo o feitio da árvore; estas amputações devem ser feitas com muito tento e aos poucos, a fim de que não padeçam as raízes, como já foi explicado.

Outra observação muito essencial é que as árvores não dão frutos no centro; de maneira que os galhos do centro, não só são inúteis, como prejudiciais porque impedem o ar, a luz e o calor de penetrarem a árvore, como porque servem de ninho aos insetos nocivos, como brocas, aranhas, lagartas, etc.

Um meio de obter frutas mais doces e mais bem desenvolvidas é caiar, no tempo da seca, os troncos das árvores frutíferas; a cal não só destrói o musgo que adere às árvores, como as ovas dos insetos nocivos depositados nela. 


\subsubsection{Poda das árvores.}

Para se fazer uso da tesoura de podar (secator) é preciso conservar o gancho pela parte de cima e a folha pela parte de baixo; também se usa do podão para os galhos que se dirigem horizontalmente.

\subsubsection{Poda em espaldeira.}

O princípio geral adaptado na poda das árvores e particularmente dos pessegueiros é de tirar os galhos inúteis e dar à seiva uma direção mais vantajosa e à árvore meios de produzir frutos em abundância.

Este é o fim que se deseja alcançar pelo meio da poda.

O método mais seguido em França consiste em escolher uma árvore da qual se corta a copa, deixando unicamente dois galhos dos lados, os quais são dirigidos de maneira a deixar um angulo de $90^{\circ}$ entre si, a fim de obrigar a seiva a dirigir-se sobre os lados; porque se se deixassem ramos verticais, poucos galhos nasceriam dos lados e os poucos que existissem logo feneceriam; sobre estes dois galhos, chamados galhos mestres, deixam-se nascer outros, que também se inclinam a fim de conter a seiva; estes novos galhos chamam-se membros e produzem os galhos frutíferos que enchem os intervalos.

Deve-se ter cuidado em manter a seiva igualmente nos dois lados, sem o que, logo um lado se desenvolveria a custa do outro, que logo secaria; e para este fim, logo que se vê um lado exceder em vegetação ao outro, trata-se de lhe tirar alguns galhos, a fim de manter o equilíbrio da seiva.

Esta poda chama-se "poda em espaldeiro", que se assenta contra uma parede, estacada, etc.: é mais apropriada para os pessegueiros, damasqueiros, ameixeiras, macieiras, pereiras; e dá excelentes resultados, apresentando frutos abundantes e deliciosos em árvores que não ocupam quase nenhum espaço.

\subsubsection{Poda em pirâmide.}

Esta é a melhor forma de dar às pereiras, laranjeiras, macieiras, cerejeiras, para colocar um número maior em um espaço dado; deve-se dar à parte de baixo um diâmetro igual a terça parte da altura total.

\subsubsection{Poda em vaso.}

Convém para as árvores anãs, ou que se querem conservar em estado de anãs; e para este fim, é preciso cortar os galhos da copa e deixar os dos lados.

Para fazer os raminhos (ramilhos) darem frutos, deve-se tirar o olho da ponta, exceto se este der esperanças de dar fruto. 


\subsubsection{Fazer um mesmo pé dar flores diferentes.}

Um meio muito engenhoso de fazer um mesmo pé das flores diferentes consiste em ligar juntos diferentes galhos ou ramos de plantas, que se acham próximas, são previamente cortados até na metade, cada um deles, de maneira a fazer um enxerto de justa posição, depois de pegados corta-se um deles, e assim se alcança o fim desejado. As camélias, murtas, roseiras, jasmins, etc. são plantas muito próprias para este fim.

\subsubsection{Fazer germinar as plantas com brevidade.}

A sociedade botânica de Londres fez há pouco tempo uma experiência digna de interesse sobre as sementes remetidas do Cabo da Boa Esperança.

Tendo-se posto estas sementes a ferver dentro d'água por espaço de três, seis, e quinze minutos, germinaram prontamente, logo que as enterraram.

Resulta desta experiência que com a exposição à ação da água a ferver, ficam livres as sementes dos insetos que as roem, sem que se lhes altere o princípio vital.

Também livram os vegetais dos insetos, mergulhando-os numa dissolução concentrada de pedra-ume, de nitro ou de sal, misturada com igual quantidade de espírito de vinho.

\subsubsection{Enxertos de tomates sobre batatas.}

Os pés do tomate enxertam-se com pleno sucesso na batateira, pelo método dos enxertos herbáceos introduzidos por Ischudy.

Por este curioso meio obter-se-ão plantas que darão duas qualidades de frutos, uns subterrâneos - batatas - e outros aéreos - tomates.

O enxerto liga-se cuidadosamente e cobre-se com papel, para o preservar do ardor demasiado do sol, por espaço de cinco a seis dias.

É maravilhoso ver como a arte transforma por tal modo e tão completamente a natureza!

\subsubsection{Meio de aumentar os frutos de uma árvore.}

Quando a seiva superabunda numa árvore frutífera, aumentam-se as frutas, sangrando a árvore, ou cortando algumas de suas raízes.

Há outro meio também que consiste em bater com um macete o tronco da árvore, todo à roda, contanto que não se estrague a árvore e isto deve ser um pouco antes das árvores quererem principiar a brotar. 


\subsubsection{Das árvores anãs.}

As árvores anãs adornam uma horta ou um jardim. Tiram-se as árvores anãs dos ramos de qualquer fruteira que vão dar fruto naquele ano: as de espinho conseguem-se ordinariamente por alporque, e as outras por enxerto.

Para conseguir, v. g. pereiras anãs, enxertam-se em marmeleiro garfos de qualquer qualidade de pereira (as do inverno não produzem bom fruto).

Os garfos não devem ser tirados das hastes mais vigorosas; porque se desenvolvem muito: devem ser enxertadas a seis polegadas acima da terra: e quando o enxerto tiver crescido um palmo, cortam-se-lhe os 2 gomos, a fim de obrigá-lo a dar ramos laterais.

Dois anos depois se transplantam para o jardim, onde se continuam a aparar, a dar-lhes a forma conveniente e o tratamento necessário.

Assim se terá uma oliveira em um vaso dando azeitonas, uma figueira, uma cerejeira, uma laranjeira, etc.

Os damasqueiros, ameixeiras e pessegueiros anãos produzem melhor, e se Ihes dá melhor forma em latadas, ou crucificados às paredes.

Quanto mais se decotarem as árvores depois de darem fruto, melhor produzirão no ano seguinte, e maiores e mais saborosos serão os seus frutos.

\subsubsection{Processo para apressar a madurez dos frutos.}

Este processo consiste em apertar com um arame, a algumas polegadas da sua forquilha, o galho de uma árvore; a seiva descendente é detida em sua marcha por causa da ligadura; forceja sobre as frutas com grande abundância que aumenta sua grossura e ativa rapidamente a sua madurez.

\subsubsection{Maneira de reavivar as árvores doentes.}

Qualquer que seja o estado de doença de uma árvore bastará, para a fazer renascer e dar às folhas a cor verde, sinal de boa vegetação, regá-la com uma dissolução de sulfato de ferro, na proporção de 3 oitavas em uma garrafa d'água.

Este sal baratíssimo, e que se acha em toda a parte, é de uma vantagem imensa na agricultura, pois que produz resultados admiráveis.

\subsubsection{Meio de conservar as flores.}

Toma-se um ramalhete de flores e borrifa-se-o com água fresca; põe-se dentro de uma solução de água e sabão, que o nutrirá e conservará as flores. 
Todas as manhãs tira-se o ramalhete da água de sabão, deixa-se por alguns instantes o pé dentro da água fresca, conservando o ramalhete pouco inclinado; borrifa-se de novo com água fresca e torna-se pôr o ramalhete dentro da água de sabão.

A água de sabão muda-se de 4 em 4 dias.

Desta maneira se conservará um ramalhete de flores 1 mês e mais.

Se se quiserem conservar as flores por um tempo indefinido, põe-se, por diferentes vezes, o ramalhete dentro de uma água gomosa, tendo-se o cuidado de não repetir a operação senão depois que a primeira estiver seca; as flores destarte ficam cobertas de uma leve camada de cristal, que não lhes tira nada de seu brilho.

\subsubsection{Maneira de conservar as flores e os frutos.}

Os frutos e as flores podem ser preservados de apodrecer e de murchar imergindo-os em uma solução de goma arábica, duas ou três vezes. Mediando entre umas e outras o tempo preciso para a goma secar.

Este processo cobre a superfície do fruto com uma leve camada de goma, que é inteiramente impermeável ao ar e assim impede os frutos de apodrecerem e as flores de murcharem.

Algumas pessoas têm rosas assim conservadas com toda a sua beleza e perfume, como se acabassem de serem colhidas, apesar de terem sido apanhadas há meses.

Para obter-se resultado em experiências deste gênero, é necessário ter cuidado em que a totalidade da superfície seja completamente coberta, porque se o ar puder penetrar pelo mais pequeno interstício, todo o trabalho é perdido.

Quando se trata de conservar os frutos, deve haver particular atenção em cobrir o pé.

O melhor meio é atar um fio de seda ao pé e então mergulhar o fruto devagarzinho na solução, que não deve ser tão forte que contenha a mais pequena partícula de goma por desfazer-se.

A goma é tão transparente que com dificuldade pode descobrir-se a sua presença, exceto pelo tacto. Por este motivo, os objetos assim preparados apresentam sempre a mesma frescura, como se acabassem de ser colhidos.

\subsubsection{Modo de conservar flores frescas por muito tempo sem murchar.}

É muito vulgar ornarem as salas com vasos de flores, que se colocam dentro d'água para conservá-las frescas por algumas horas. Mas ajuntando-se a esta água uma colher de sal de cozinha, estas flores conservam-se frescas por oito ou mais dias. 


\subsubsection{Frutas: outro meio de as conservar.}

Tendo-se colhido em tempo seco frutas que não estejam maculadas, metemse em uma estufa por quatro ou cinco dias. Passado este tempo, derrete-se cera branca, à qual se ajunta um pouco de sebo e mergulham-se dentro as frutas para que tomem uma camada igual. A cera só deve estar morna para não escaldar a fruta. Se uma camada não guarnecer perfeitamente, dá-se outra. Embrulham-se em papel e metem-se em farelo. Querendo comer-se a fruta, basta apertá-la entre as mãos, porque a casca de cera quebrar-se-á logo.

Este meio fica um pouco mais caro para as primeiras despesas, mas a cera não perde a sua qualidade nem valor.

\subsubsection{Processo para obter frutos de uma grossura extraordinária.}

Depois de se ter enxertado o garfo de uma planta sobre um tronco qualquer, $\mathrm{e}$ se sobre este garfo, depois de brotado, se fizer novo enxerto, e sobre aquele um outro em seguida, obter-se-ão frutos de descomunal tamanho, sabor e aparência.

\subsubsection{Processos para obter quaisquer qualidades de plantas de mui- ta grossura.}

Devem se pôr as sementes em terra, na ocasião em que o sol sobe ao equinócio de março, o que é sempre fácil saber-se com uma folhinha; porém se houver alguma dificuldade em saber a hora certa para o ponto culminante do equinócio, bastará pôr cinzas de parreira em uma vasilha vidrada com água bem limpa desde o dia 20 de março; quando o sol subir ao seu ponto equinocial, ver-se-á a cinza turvar-se com a água, o que será uma prova do sol ter chegado ao ponto desejado.

Quando as sementes estiverem nascidas e em ponto de serem mudadas, deverá fazer-se no princípio da lua cheia.

\subsubsection{Colchões de musgo.}

Com os musgos que se acham nas matas, fazem-se colchões muito macios e muito próprios para a saúde. Nada mais é necessário do que pôr o musgo ao sol e, depois de seco, confeccionar com ele os colchões, como se pratica com os de cabelo.

Depois do musgo muito amassado, torna-se descoser os colchões, querendo, e depois do musgo exposto ao sol e batido com varas, tornar-se-á tão próprio como da primeira vez.

Estes colchões têm a propriedade de serem muito macios, muito frescos, e tem a propriedade que não tem os mais colchões, fabricados com outros materiais, são anti-reumáticos, antifebris e conservam o corpo sempre em boa disposição e com energia para os trabalhos, quer físicos, quer intelectuais. 


\subsubsection{Modo de conhecer as mudanças de tempo pelos meteoros.}

Alguns indícios se podem ter de próximas mudanças de tempo, por observações simples que estão ao alcance de todos; e isto se torna muito necessário aos que se ocupando de lavoura não possuírem barômetros simples ou compostos, e outros instrumentos próprios para indicarem as revoluções atmosféricas.

E são os seguintes: Quando o sol parece cercado por massas circulares de vapor, estão para vir nevoeiros, chuva ou neve.

Quando, por diante do sol, passam nuvens, que tomam, pela ação dos raios solares, cor vermelha, amarela ou verde, está próxima a chuva.

Quando, no tempo quente, se vê o sol, ao nascer, coberto por massas espessas de nuvens que o ocultam, deve-se esperar de tarde uma trovoada.

Se em tempo chuvoso ou nebuloso, o sol, quando se põe, é visto distintamente em uma região clara da atmosfera, reinando vento do oeste, é sinal de bom tempo, ao menos por 24 horas.

Durante os ventos de oeste, nada se pôde predizer quando o sol nasce em região clara, no meio da atmosfera pura, sem nuvens; pelo contrário, quando reina leste, o erguer do sol sereno, anuncia sempre um belo dia.

Massas de vapor circulares em torno da lua anunciam também chuva ou neve próxima.

Se se alargando, esses círculos se tornam vermelhos, anunciam vento; se do vermelho a cor passa ao amarelo, é indicio provável de uma próxima tempestade.

Quando a lua se acha inteiramente oculta por um véu de nuvens, é sinal quase certo que a chuva depressa cairá.

Quando pequenas nuvens brancas passam lentamente e em grande número por diante da lua, pode-se esperar por um belo dia.

Se, em tempo sereno, as nuvens se reúnem em flocos, é sinal de que o bom tempo será duradouro.

Nuvens numerosas e em massas espessas e escuras, anunciam ventania do sul.

Quando as nuvens mais altas caminham em sentido diverso daquele em que se dirigem as mais baixas, está próxima a mudança de vento.

O aparecimento de nevoeiros pela manhã indica ordinariamente tempo bom e frio; o aparecimento da névoa ao meio dia é quase sempre indício de chuva.

Quando, em tempo de grande calor, vemos repentinamente, nevoeiros espessos reunidos em massa sobre certos pontos, quase sempre é sinal de chuva e tempestade. 
Os nevoeiros que se formam sobre os rios e aí se conservam, são seguidos quase sempre de mau tempo; as que se afastam da superfície das águas indicam, de ordinário, tempo bom.

O vento de leste anuncia tempo seco e sereno: o de oeste indica tempo úmido e chuvoso.

O vento do norte, no verão, anuncia tempo seco, e no inverno tempo frio: o nordeste anuncia tempo mais seco no verão, e geada no inverno: o noroeste anuncia tempo úmido, chuveiros, frio e, algumas vezes, neve.

$O$ vento sul anuncia tempo quente e úmido o sueste mais calor e secura; e o sudoeste mais umidade e calor, e, por conseqüência, tempo mais fresco no verão e mais brando no inverno.

O vento que começa a soprar durante o dia dura mais tempo do que o que começa de noite.

Se não há vento e o horizonte não tem nuvens, continua bom tempo; mas se o calor é excessivo, pode vir uma trovoada.

Dura pouco, de ordinário, o vento que não sopra seguidamente.

O trovão da tarde e da noite anuncia tempestade próxima; o do meio dia anuncia chuva; e o da manhã é quase sempre precursor de grandes ventos.

Pelos diversos intervalos de tempo, entre relâmpagos e trovões correspondentes, podemos saber se uma trovoada se aproxima ou afasta de nós.

O arco íris aparece ordinariamente no fim da chuva; mas quando, acabada ela, aparece com um arco duplo, e com vivas cores, é sinal de que a chuva vai de novo aparecer.

Se existe já arco íris durante a chuva, é provável que a água venha a cair em maior quantidade.

\subsubsection{Remédio contra os efeitos do raio.}

Logo que a pessoa for atacada de raio, dever-se-á enterrá-la, imediatamente e nua, em terra novamente revolvida, e conservá-la assim, com a cabeça de fora, até que apareçam melhoras sensíveis.

\subsubsection{Desinfecção das matérias fecais.}

Pós desinfetantes. Sulfato de ferro: 100 partes; sulfato de cal: 130 partes; sulfato de zinco: 5 partes; carvão vegetal: 5 partes.

Cinco oitavas destes pós lançados na cloaca, desinfetam-na. 


\subsubsection{Sanguessuga servindo de barômetro.}

Tem-se observado que as sanguessugas, guardadas num vidro de boca larga e cheio de água acima da metade, servem para adivinhar o tempo.

Se o tempo está bonito, ou que se vai tornar bonito, a sanguessuga fica sem movimento emboscada no fundo do vidro.

No tempo de geada, ela conserva a mesma posição.

Se estiver para chover, ela sai do vidro e agarra no pano que tampa o vidro, e aí fica enquanto chove; se o tempo está para consertar-se, ela torna a descer ao fundo do vidro.

Se dever ventar, a sanguessuga nada com espantosa rapidez.

Se deve haver grande trovoada, ela fica fora da água e mostra, por espasmos e movimentos convulsivos, um incômodo extraordinário.

\subsubsection{Cultura e fabricação do Anil.}

Pelo sistema mais moderno e vantajoso; semeiam-se em fins de Março as sementes do anil, podendo servir a terra onde está plantado o milho; em Outubro faz-se a primeira colheita e, em Dezembro, a segunda colheita dos ramos; deitamse estes em uma vasilha qualquer, e pondo em cima algumas pedras para ficarem no fundo quando se despejar água quente em cima, devendo a água cobrir perfeitamente os ramos; deixe-se assim de infusão entregue à fermentação até aparecer na superfície, uma escuma cor de arco-íris; tira-se então esta água para outra vasiIha e, depois de ter ajuntado um pouco de água de cal, bate-se este líquido com vassouras de ramos verdes até levantar uma escuma azul; primeiro se torna a água verde, ficando cada vez mais escura, até que por fim toma uma cor azul, ficando ao mesmo tempo meio grossa; deixa-se então repousar e, passados dias, despeja-se a água limpa que está por cima do pó do anil, que se assentou no fundo, tirando-se este, seca-se ao sol.

\subsubsection{Cultura e preparação da Cochonilha.}

Faz-se para esta cultura, plantações de cactus opuntia, e como esta plantação prospera em terreno seco, pode-se aproveitar e tirar grandes vantagens de um terreno que antes estava inutilizado; a planta do cactus opuntia enraíza muito bem, fazendo um rego, e afincando de 5 em 5 palmos uma folha; no ano seguinte, enxertam-se nestas plantas os bichos da Cochonilha, segurando em cada planta um ninho com alguns ovos do bicho; em poucos dias saem destes casulos milhares de bichos que cobrem a planta, passados por suas metamorfoses, crescendo seguros 
na planta e, tendo chegado no seu maior desenvolvimento, ficam as fêmeas imóveis, os machos criam asas e procuram as fêmeas, e morrem depois de as ter fecundado; neste estado ajuntam-se as fêmeas com uma escovinha sobre um pano colocado ao pé da planta, e secam-se num forno de torrar farinha; deixando algumas para continuar a produção. Tiram-se 3 colheitas por ano, dando cada planta 1 onça de cochonilha seca.

Exporta-se do México anualmente 500 a 600 mil libras, que se vendem de 4 e 5000 a libra, rendendo assim cada pé 200 a 300 réis.

\subsubsection{Criação dos bichos de seda.}

Esta nota foi-nos remetida por uma pessoa muito competente neste objeto e acreditamos, por conseqüência, que seja verdadeira.

Os bichos de seda passam por 5 mudas de pele de 7 em 7 dias; a cada muda adoecem; a cabeça incha ou intumesce, deixam de comer e, como que se dormissem, largam a capa com que estavam vestidos.

Continuam as suas mudanças por esta forma até a $5^{\text {a }}$ muda, nesta última época principiam a comer desde o $7^{\circ}$ ao $9^{\circ}$ dia.

Abandonam finalmente todo o alimento e chegam ao maior comprimento no corpo.

A cor é de um amarelo mais carregado.

As costas são luzidias, brancas e frouxas. Os anéis do corpo douram-se ligeiramente.

O vermelho do focinho clareia, bem como a parte posterior do corpo.

Agita-se, deposita todos os excrementos, anda sobre o tabuleiro e move verticalmente a cabeça, até achar sítio conveniente em que possa deitar os primeiros fios.

Deve-se ter todo o desvelo em que nem ratos, formigas, moscas ou mosquitos possam incomodar os bichos.

Ter todo o desvelo no asseio dos tabuleiros.

Não faltar comida, e que seja dada 4 vezes, nas 24 horas, em tempo determinado.

Ter sempre folha com fartura e de véspera, para nunca lhes dar com a menor umidade, sendo mais conveniente não lhes dar do que comerem na umidade.

Tratar de separar nos tabuleiros os bichos segundo sua idade, e não mexer nos que estão de cabeça inchada e sem movimento; porque estão na ocasião em que se lhes não toca, nem mesmo se lhes dá folha, não só porque a não comem, como porque se lhes evita a frialdade e perturbação. 
Todo o cuidado no grau de calor dentro da casa, e só renovar-lhes o ar na ocasião de não haver nem vento nem umidade, o que para os bichos é tudo pior.

\subsubsection{Criar abelhas.}

As colméias fazem-se de quatro tábuas de dois e meio palmos de altura; atravessando-se dentro três ou quatro varinhas, pregando um outro pedaço de tábua como tampa; com este caixão chega-se para o enxame e, se este está pendurado num galho, esfregam-se as tábuas do caixão com erva cidreira; com umas folhas ou ramos varrem-se as abelhas para dentro do caixão, que se deposita sobre um banquinho perto do chão; passada meia hora, tendo-se recolhido a maior parte das abelhas para o caixão, leva-se e deposita-se o na colméia, sobre uma prateleira coberta com telha ou esteira, assentada sobre esteios afincados dentro de água; o telhado é para abrigar as colméias do sol muito quente ou da chuva, e os esteios afincados na água para as formigas e outros insetos não poderem subir para as colméias. As abelhas principiam logo a trabalhar, prosperam. Produzem mel e cera, sem haver outro trabalho além do de recolher os enxames que perfilham; e em Agosto e Fevereiro, tira-se-lhes o mel e a cera produzida; espera-se para esta ocasião que a colméia tenha dado um enxame e, passados 22 dias depois deste ter saído, espera-se esta ocasião para dar tempo à nova criação sair dos casulos, para não estragar os filhotes, e mesmo fica o mel e a cera; tendo os favos ainda muitos filhotes sujos, é mais custoso de purificar: inclina-se a colméia um pouco para não a sacudir; e trazendo-se brasas em uma telha, sobre as quais se deitam alguns pedaços de baeta e pano, sopra-se a fumaça que se desenvolve para dentro da colméia para tontear as abelhas; sendo a colméia bem enfumaçada, vai-se com ela para um quarto escuro e fechado; tira-se a tampa e uma tábua lateral; cortando-se todos os favos que não tem produção; tornando depois a pregar estas tábuas, e levando-se a colméia para seu lugar; e tendo tido o cuidado de tontear as abelhas com fumaça, não se necessita de máscara nem de luvas, porque as abelhas ficam mansas como moscas; estes favos espremem-se então numa imprensa, ou mesmo entre as mãos, coando depois este mel por um pano grosso; a cera espremida deita-se num tacho com bastante água, e ferve-se até a cera ter-se derretido toda; tira-se então o fogo, e depois de esfriar, tira-se a cera, e côa-se a água, que contém ainda muito mel e pode ser engrossado a ponto de xarope.

\subsubsection{Depuração do Mel.}

Tomam-se de carvão de braúna bem luzente e reduzido a pó grosso, 12 onças. Peneira-se para lhes tirar todo o pó fino, que não serve para esta operação.

Lava-se o pó grosso mui bem, e depois deita-se em um tacho com 2 canadas d'água e 8 libras de mel. Faz-se ferver por uma hora, passa-se depois por um pano 
para o coar, e torna ao fogo. Batem-se duas claras de ovos, para as reduzir à escuma e quando o mel principia a ferver, deita-se lhe uma porção de escuma e mexese. Deixa-se ferver, tirando a escuma que se forma na superfície do líquido com escumadeira. Passados 10 minutos mais ou menos, torna-se a lançar outra porção de clara em escuma. A fervura continua, e mediando o mesmo tempo, deita-se-lhe ainda mais 2 vezes a mesma clara batida.

Nesta segunda operação o mel deve estar há uma hora ao fogo a ferver brandamente até estar na consistência de mel novo. Depois de frio, guarda-se. O mel assim preparado fica muito límpido, sem cheiro, e de sabor agradável.

As geléias com ele feitas, assim como a de pêssegos, damascos, ameixas, marmelos, maçãs, ficam primorosas e de grande duração.

O método de as preparar é o mesmo que se pratica sento feitas com açúcar.

\subsubsection{Meio de afugentar as formigas.}

Faz-se uma mistura rala de fuligem de ferro e óleo de linhaça bem incorporado; estende-se uma camada deste misto sobre o tronco das árvores, nos buracos dos cortiços de abelhas, ou em outro qualquer lugar que se queira preservar das formigas.

\subsubsection{Meio de acabar com as formigas que não se pode perseguir em seus ninhos.}

Já se explicou como se pode dar cabo dos formigueiros de formigas grandes, ou carregadeiras; resta saber um meio pelo qual se possa acabar com as formigas pequenas, chamadas doceiras que principalmente perseguem as dispensas; enleia-se, para este fim, com capim, uma garrafa cuja boca se unta com um pouco de água com açúcar, e pondo-se dentro uma colher do mesmo; coloca-se esta garrafa perto do formigueiro ou em lugar onde se vêem passar muitas formigas; em pouco estará a garrafa cheia de formigas: que se matarão facilmente com um pouco de água quente.

\subsubsection{Meio de afugentar as formigas doceiras.}

Ponha-se nos armários, copas, aposentos freqüentados por formigas doceiras, algum pouco de fumo picado e estas imediatamente se retirarão.

\subsubsection{Outro.}

Também se serve, para o mesmo fim, de uma decocção de arruda que se lança sobre as formigas; ou lavando com esta decocção os armários, as prateleiras onde elas costumam estar. 


\subsubsection{Meio de destruir os insetos nos quintais.}

Para este efeito, é suficiente regar com água de batatas ou de mandioca as plantas infectadas de insetos.

\subsubsection{Meio de preservar as árvores das formigas e de outros insetos no- civos.}

Faça-se uma mistura de uma parte de clorureto de cal com duas partes de banha ou de mel, e impregna-se com esta massa uma porção de estopa, ou trapos de tecidos grossos, amarrando-os em redor do tronco; também serve do mesmo o alcatrão: qualquer destas substâncias impede que os insetos possam subir a árvore.

\subsubsection{Meio de destruir o pulgão das arvores.}

Queime-se palha debaixo das árvores; e quando o fumo estiver quase dissipado, borrifem-se com água de cal, em que se tenha misturado alguma folha de tabaco fermentada ou podre.

Se as árvores estiverem muito carregadas de pulgão, será necessário repetirse mais vezes esta operação.

\subsubsection{Meio simples de destruir as lagartas.}

Como este animal é muito inimigo das plantas, trataremos de dar aqui algum meio de o destruir.

Faça-se uma mistura de duas libras de terebintina fervida em seis libras d'água; borrifando-se as plantas ao anoitecer com esta solução, livram-se das lagartas.

\subsubsection{Outro.}

Para se obstar que as lagartas acometam as plantas, atam-se sobre a planta tiras de casca de amoreira, ou também recorre-se aos meios estabelecidos para se afugentar as formigas.

\subsubsection{Contra o pulgão e o percevejo da terra.}

Para se evitarem estes animais, semear-se-ão entre as couves e outras hortaliças sementes de rábão, planta esta que tanto o percevejo como o pulgão gostam muito, e assim deixam as outras plantas, comendo somente as do rábão.

\subsubsection{Remédio contra as lesmas e os caracóis.}

Aqueçam-se até ficarem macias, algumas folhas de repolho, e untem-se de manteiga, ou unto sem sal; e pondo-se estas nos lugares infectados desses insetos, estas folhas em breve estarão cobertas por eles e assim podem ser destruídos. 


\subsubsection{Segredos para apanhar ratos.}

Põe-se sobre um barril com água, uma tampa móvel bem equilibrada e atravessada por um eixo nos dois lados; põe-se um pouco de toucinho na extremidade desta mesma tampa; e quando o rato vai apoderar-se da isca, a tampa vira-se e torna a conservar a sua posição primitiva, tendo neste movimento deixado cair o rato que perece na água.

\subsubsection{Outro.}

Corta-se uma esponja em pedaços do tamanho de uma noz, os quais se frigem em gordura, pelo que, murcham; pondo-se estes pedaços nos lugares onde aparecem os ratos, estes os comem com avidez; ficando porém, com sede, bebem água, com a qual as esponjas incham e os ratos arrebentam.

\subsubsection{Outro.}

Toma-se uma dúzia de ratos vivos que se fecham em uma ratoeira, sem se Ihes deixar alimento; estes acossados pela fome tratarão de comer uns aos outros; o mais valente ficará por ultimo, só; e se se o soltar, este acostumado a comer os seus semelhantes, não procurará outro alimento, e se tornará um gato feroz que os destruirá todos.

Ha exemplos incontestáveis da eficácia deste recurso.

\subsubsection{Outro.}

Põe-se um pouco de visgo nos lugares por onde passam os ratos; logo que se acham untados desta droga que adere ao pelo, inquietam-se de tal forma, que chegam a esfolar-se para se livrarem deste incômodo, e abandonam para sempre um lugar onde sofreram tal desastre.

\subsubsection{Outro.}

Mistura-se fubá de milho com um pouco de manteiga e lança-se em cima uma ou duas gotas de óleo de anis; fazem-se bolos que são as melhores iscas para pôr nos laços de apanhar ratos.

\subsubsection{Dos vernizes.}

Dá-se, nas artes, o nome de verniz à toda a matéria líquida que aplicada na superfície dos corpos, tem as propriedades de torná-las luzentes e de os fazer impenetráveis à umidade e as mais influências do ar, sem lhes destruir a cor nem alterar o polido. Distinguem-se três gêneros de vernizes, os quais tomam os nomes 
de seus dissolventes, a saber: chamam-se vernizes de espírito de vinho, os que com ele são preparados; de essência, os que são preparados com terebintina; e, finalmente, vernizes gordos ou graxas, os que são preparados com óleos.

As mais substâncias que entram nestas composições são as resinas e as gomas resinosas. Entre estas últimas, algumas há que são mui rebeldes à solução; porém sendo combinadas com outras mais solúveis, prestam-se mais facilmente a este efeito. É de extrema precisão nesta arte conhecer o estado das drogas que nela entram; se estão falsificadas, se são realmente as próprias, e seu grau de pureza; sem estes conhecimentos, nunca as preparações desta natureza poderão corresponder aos desejos do operário, por mais que se canse e se esmere para as alcançar.

\subsubsection{Colheita de terebintina.}

A terebintina escorre espontaneamente de todas as qualidades de pinheiros; alguns pinheiros têm esta resina em tanta abundância que ficam por ela sufocados e secam, se não se podem livrar da mesma por alguma racha; cada pinheiro dá todos os anos 20 a 50 libras de breu; poderão muitas pessoas pobres alimentaremse ou ganharem algum dinheiro com este pequeno trabalho que consiste em ferir os pinheiros, em fins de Agosto, com um golpe de alto abaixo de 4 a 5 palmos de comprimento, meio palmo de fundura e uma polegada de largura; segurando na base uma bica de taquara, por onde a resina pode correr, para uma vasilha que se porá por baixo.

Esta operação não prejudica os pinheiros, tendo-se o cuidado de não ferir pinheiros muito novos; estes devem ao menos ter 4 a 5 palmos de circunferência, e podem depois ser feridos todos os anos pelo espaço de 50 a 60 anos, tempo em que um pinheiro pode dar uma, até uma e meia arroba de resina; ou 400 pinheiros podem dar todos os anos 100 até 150 arrobas de resina.

\subsubsection{Bálsamo de Copaíba.}

Semelhante à antecedente é a colheita do bálsamo de copaíba; fura-se, em fins de Agosto, os bálsamos oleosos, com um trado, enfiando neste furo um canudo; na extremidade do canudo põe-se uma vasilha coberta, para não cair cisco no óleo; cada árvore pode ser furada de dois lados e darão, até fins de Dezembro, de 8 a 10 libras; tirando-se neste tempo os canudos e tapando os buracos com cera para no ano seguinte tornar-se a tirar óleo, metendo os canudos nos mesmos buracos.

\subsubsection{Das matérias sólidas que entram nas composições dos verni- zes; sua escolha e preparações.}


Alambre que também se conhece sob o nome de Carabe de Electrum, e ainda de âmbar amarelo, ou de súcino. Substância resino-vegetal em estado fóssil; sólido e mui transparente de cor amarela escura, ou também mui branco, friável e sem cheiro algum. Exposto ao calor de brasas, arde com chama, exalando cheiro resinoso agradável; e não deixa resíduo algum. Abunda no comércio, e vem da Prússia, onde o apanham por toda a costa do Mar Báltico. O alambre é solúvel, em parte, no álcool, e nos óleos fixos e voláteis. Deve-se escolher o mais transparente e o mais carregado em cor, porque a experiência mostra que este é muito mais fácil em dissolver. Esta droga aparece muitas vezes falsificada com a melitis ( $n$. do e.: provável melito, composto cujo veículo é o mel), e outras vezes com diferentes resinas fósseis; porém, esta fraude é logo conhecida porque o alambre derrete-se ao calor elevado, até ficar em consistência de mel, enquanto que as outras substâncias não tomam fusão e se tornam pulverulentas.

O alambre, antes de entrar nas composições dos vernizes, deve passar por uma preparação, que vem a ser: lavá-lo bem e, depois de enxuto, reduzi-lo a pó grosso; derrete-se então em um pequeno tabuleiro de folha de ferro, e quando está em consistência de mel, tira-se do fogo e cobre-se até estar inteiramente esfriado: reduz-se, então, a pó e guarda-se em vidro bem arrolhado.

O alambre perde, assim preparado, metade do seu peso pela evaporação da substância óleo-resinosa, e fica mui fácil de dissolver nos veículos apropriados.

Neste estado toma o nome de alambre preparado.

\subsubsection{Alcanfor ou ainda Cânfora.}

É substância particular, que constitui uma das substâncias imediatas dos vegetais.

Depois de depurado o alcanfor é branco, transparente, untuoso ao tato, dúctil e de sabor amargo, quente e picante, amalgamando-se nos dentes como a cera, ao mastigar-se: é muito inflamável e pouco solúvel n’água; porém dissolve-se prontamente no álcool (espírito de vinho retificado), nos óleos voláteis, e também nos óleos fixos.

A maior quantidade de alcanfor que aparece no comércio vem do Japão, onde o extraem abundantemente do laurus canphora.

Deve escolher-se o mais cristalino.

As quantidades de alcanfor que entram nos vernizes hão de ser mui limitadas para não os fazer farinhosos.

Facilita a solução de várias resinas que se mostram rebeldes ao solvente, tais como a copal e outras, e dá elasticidade a alguns vernizes; mas, segundo a regra de Tingry, não deve entrar mais do que até meia onça por cada libra de álcool; e cinco oitavas para cada libra (peso) de essência. 


\subsubsection{Almécega ou ainda Mástica.}

Goma resina friável, de cor citrina, com cheiro balsâmico agradável, muito inflamável, em pequenas lágrimas mui diáfanas, em cuja forma se recolhe pelas incisões feitas nos ramos do pistacia lentiscus, que em português chamam vulgarmente aroeira, arbusto que abunda muito no Mediterrâneo e nos sertões de Minas e S. Paulo.

A que vem da Índia é superior, e por isso se deve preferir.

Entretanto, a mais pura é a almécega que vem de Chio; mas é rara, porque as damas turcas a ambicionam muito para a mastigarem, com o fim de conservarem os dentes mui claros, as gengivas muito firmes e terem bom hálito, pelo seu sabor adocicado e balsâmico.

A que vem de Marselha é sempre adulterada com outras resinas que se the assemelham, trazendo, as mais das vezes, a mistura da goma graxa ordinária; falsificação esta que logo se conhece, porque mastigando-se a almécega, reduz-se a um estado tão brando e tão unido, que puxada nos dedos, forma corda ou fio, enquanto que todas as mais que a podem adulterar, não gozam desta propriedade, pela razão de se reduzirem a pó entre os dentes, deixando um sabor semelhante ao da terebintina.

\subsubsection{Goma resina Anima (em francês, Résine animée).}

Esta droga vem das Antilhas, da América meridional e das Índias.

É tirada por incisões praticadas nos troncos da hymenea courbaril.

Deve-se escolher a que se encontrar em pequenas massas, de cor amarela esbranquiçada, cheia de veios brancos opacos por dentro, quebrando-se facilmente entre os dedos e inflamando-se a luz de vela, dando uma chama mui branca, sem deixar resíduo algum depois da combustão.

Lança de si um cheiro suave enquanto arde e é mui necessária nos vernizes alcoólicos porque lhes dá consistência e os torna mui elásticos.

É preciso muita cautela com a escolha desta resina, porque quase sempre vem falsificada, trazendo em mistura a goma copal mais corada; e isto sucede por não ser a goma anima assaz abundante, mesmo nos climas que a produzem, pelo que, pouca aparece no comércio que seja verdadeira.

\subsubsection{Urucu (em francês, Roucou ou rocu).}

Substância colorante para dar aos vernizes a cor de ouro.

Esta droga vem das Índias orientais, onde a preparação com o suco da semente da Orelana (bixa de Líneo), por longas macerações; no Brasil cultiva-se o urucu em grande escala. 
Aparece no comércio em massas redondo-alongadas e, outras vezes, em pastas duras, quando está muito seca.

A sua cor externa é parda e, por dentro, avermelhada.

Escolhe-se a mais compacta e encarnada, bem seca e de sabor amargo, deixando na saliva uma tintura amarela cor de ouro.

\subsubsection{Asfalto ou betume judaico (em francês, Asphalte, ou poix minérale).}

Substância betuminosa que parece participar das matérias vegetais e amimais.

Acha-se nadando na superfície das águas do Lago Asfáltico na Judéia; endurece-se pelo calor do sol e pelos ventos que sopram naquela região; aparece no comércio em placas duras, mui sólidas e de uma cor pardo nigricante externamente; quebrado este betume, apresenta um aspecto negro e mui luzente, em tudo semelhante ao azeviche, com alguns veios pardos, sem cheiro enquanto frio; porém deitado sobre brasas, exala um cheiro betuminoso mui forte e penetrante.

É preciso o maior cuidado na escolha desta droga, porque muitas vezes vem falsificado com o pez negro, o que muito bem se conhece pelo cheiro de resina que deita quando se queima, e neste estado não pode servir nos vernizes.

\subsubsection{Benjoim, asa dulcis ou benzoe (em francês, Benjoim).}

É bálsamo concreto, que corre das incisões feitas nos troncos do stirax benzoin de Dryander, que se acha em Sumatra, em Java e no reino de Sião.

Acham-se no comércio duas sortes de benjoim; a primeira é o amidalóide, ou em lágrimas mui brancas e luzentes, em figura de miolos de amêndoas peladas e de sabor adocicado; a segunda variedade é em massa de cor avermelhada escura, jaspeadas de branco, de cheiro forte e mui suave.

É de fácil solução no álcool; faz os vernizes sólidos e dá-lhes elasticidade.

\subsubsection{Goma resina Copal.}

Esta resina corre naturalmente de uma grande árvore, que habita na América meridional, e que se diz ser o rhus copalinum de Lineu.

É branca ou também de cor citrina e, as vezes alambrada, frágil e sem cheiro.

As suas propriedades químicas são: dissolver-se em parte no álcool e inteiramente no óleo essencial de alfazema e, ainda melhor, na essência de terebintina; logo que é exposto por alguns tempos à luz solar, ela adquire uma densidade que torna este líquido perfeitamente homogêneo com a copal e lhe procura a sua inteira solução. 
Dissolve-se também, esta resina, prontamente, no éter, quando o peso específico deste fluido indica a sua pureza.

Segundo Tingry, a copal torna-se mais solúvel tendo passado pela preparação seguinte: Depois de a ter reduzido a pó grosso, derrete-se a fogo moderado, e quando está derretida, vasa-se as gotas em água fria: depois se seca ao sol; repete-se esta mesma operação mais uma ou duas vezes, e por fim, reduz- se a pó fino e guarda-se para o uso.

Dá-se-Ihe o nome de copal de um só fogo quando só uma vez bastou para derreter-se; de dois fogos, quando passou segunda vez por esta operação e de três, se terceira vez foi derretida, o que deve ficar de inteligência para se entenderem bem as fórmulas dos vernizes em que ela entrar de qualquer destas maneiras.

\subsubsection{Caout-chouc, vulgarmente goma, ou resina elástica.}

As propriedades físico-químicas do caout-chouc não lhe justificam a denominação de resina, nem tão pouco a de goma, e menos ainda a de goma-resina; porque se esta matéria fosse resinosa, deveria dissolver-se no álcool, o que não sucede; se fosse uma goma pura, prontamente se dissolveria nos líquidos aquosos; e sendo goma e resina, fácil seria a sua solução nos veículos próprios para dissolverem os corpos desta natureza.

É esta a razão por que esta substância não está ainda classificada em nenhuma destas três ordens, e isto por falta de conhecimento bastante da sua natureza, apesar dos continuados trabalhos dos químicos a este respeito.

O caout-chouc é extraído por incisões praticadas nos troncos de grandes árvores, às quais Lineu chamou hevea guijanensis, e os naturais das margens do rio das Amazonas, seringa e seringat; a mangabeira fornece também excelente caout-chouc.

O caout-chouc é eminentemente inflamável e espalha uma luz mui clara e brilhante, assaz duradoura.

É impenetrável à água e ao álcool, o mais retificado. Dissolve-se, dizem, com muito custo no éter sulfúrico puro.

Diz Ghaptal que quanto mais puro está este éter, menos ataca o caout-chouc, e isto é bem verdade; diz mais, que é preciso uma combinação do éter sulfúrico com o éter nítrico para se poder fazer esta solução, que deve ser logo aplicada; aliás, evaporado o éter, o caout-chouc torna a tomar o seu estado sólido, perdendo um pouco da sua elasticidade primitiva.

Nos óleos fixos e voláteis, levados a um mui alto grau de calor, o caout-chouc se liquefaz e se combina, em parte, com eles, formando vernizes gordos para fazer encerados, algálias e coisas semelhantes. 
Dissolvido nos óleos voláteis, serve para envernizar os balões aerostáticos.

3.4.96. Colofônio (em francês, Colophane, galipot, arcançon, poix résine, e encens blanc).

Em todos os tratados de vernizes, esta matéria é pedida debaixo de qualquer destes nomes.

O colofônio é o resíduo que fica da destilação da terebintina, para lhe tirar a essência chamada no comércio, aguarrás.

Os compositores de vernizes fazem o colofônio cozendo, em água simples, a fina terebintina de Veneza, até ter adquirido uma consistência sólida; depois reduzem-na a pó para se aplicar na factura dos vernizes finos.

\subsubsection{Goma resina Elemi (em francês, Elemi).}

Duas sortes desta resina se acham no comércio.

A que vem da Etiópia (e que é a verdadeira), em massas cilíndricas envolvidas em folhas de palmeira, espalha de si um cheiro forte semelhante ao do funcho.

A sua cor é branca, é um pouco esverdeada e transparente, com alguns veios avermelhados.

Quando tem adquirido, pelo tempo, consistência sólida, facilmente se abranda nos dedos e torna-se, então, pegajosa.

A segunda sorte de elemi vem do Brasil e é muito inferior a da Etiópia: vem em massas grossas e muito impura; é mole, mui viscosa, sem transparência, muito amarela, com cheiro de resina de pinho e com o mesmo aspecto, o que concorre para a sua falsificação com este material.

Não é própria, como a primeira, para a composição dos vernizes, para cujo fim se deve escolher unicamente a da Etiópia.

Esta goma, quase resina pura, dá aos vernizes elasticidade bastante e uma solidez tal, que seria dificultoso achar nas mais resinas.

\subsubsection{Goma-resina Guta (em francês, Gomme-gutte).}

Esta substância é o suco viscoso que se tira por incisões dos troncos e raízes descobertas de uma grande árvore, que é a gambegia guta de Lineu, e à qual os naturais do país chamam carcapule.

Habita na China e no reino de Sião, e existe também nas matas do Brasil.

Depois de seca, é sólida, inflamável e de cor amarela avermelhada; é mais 
solúvel no álcool do que na água; o seu princípio colorante é muito estimado nas fábricas de vernizes, para se obter a bela cor de ouro, que se aplica nos metais.

Escolhe-se sempre a mais pesada, bem unida e lisa por dentro, com cor amarela escura.

Quando esta substância se pisa para se reduzir a pó, é preciso não o respirar, porque é violentíssimo purgante.

\subsubsection{Goma-resina Laca (em francês, Laque).}

Substância resinosa, frágil, transparente, de cor vermelha amarelada, sem cheiro e de sabor adstringente um tanto amargo.

Esta droga vem das Índias orientais, onde a recolhem por exsudação do suco do fícus religiosa e do croton aciferum, cuja transudação é devida à picada de um pequeno inseto bem parecido com as formigas de asas, que ali depõe seus ovos.

Conhecem-se no comércio cinco espécies de laca: a primeira, que é a mais superior, chama-se laca em bastão, por que vem ainda pegada às delgadas hastes da planta.

A segunda é a laca de formiga, ou laca em lágrimas que vem a ser a mesma que a primeira e só difere no nome pelo estado em que nos aparece, isto é, granizada e sem mais alteração alguma do que ser despegada dos ramos da árvore.

A terceira é a laca de tira, que sendo a mesma, a derretem para falsificá-la com outras gomas resinosas, reduzindo-a depois a tiras delgadas.

A quarta espécie é a lac-lak, e a quinta é a lac-dye.

Estas duas últimas sortes de laca não servem para os vernizes; são preparadas nas Índias para servirem nas tinturarias, mas não tem tão grande aceitação na Europa, porque são inferiores à cochonilha, à ruiva, ao quermes, etc.

Em todas as composições de vernizes em que entrar a goma-resina laca, devese escolher a de formiga ou a de bastão; e só na falta destas se aplicará a de tira, escolhendo-se a mais vermelha e luzente.

\subsubsection{Goma-resina Graxa, ou goma-verniz (em francês, Sandarac, ou verniz).}

É resina tirada da thuya articulata e não do juniperus oxycedros, como se pensava.

Vem da África, da Itália e da Espanha.

Acha-se no comércio em pequenos grãos redondos ou em massas mais avultadas.

Deve ser bem clara e transparente, e esfregando-se nos dedos, deve dar um cheiro bem análogo ao da terebintina. 
Esta resina é inteiramente solúvel no álcool, nos óleos essenciais e nos óleos fixos; dá lustro aos vernizes e, misturada com a resina elemi, os faz mais sólidos e elásticos.

Chama-se verniz, à goma graxa, porque os antigos lhe deram este epíteto em razão de não conhecerem outras gomas para a composição dos seus vernizes.

\subsubsection{Sangue de drago (em francês sang dragon).}

É substância resinosa, de cor rubra muito intensa, sem sabor e sem cheiro algum estando fria.

Deitado sobre brasas, espalha cheiro resinoso, não desagradável.

Existe no comércio em diversas qualidades: o melhor é o que vem em lágrimas, e é produzido pelo calamo-ruthang.

Outras vezes vem em massas embrulhadas nas folhas do mesmo calamo.

Tira-se também por incisões praticadas no dracoena-draco das ilhas Canárias, que existe também em grande abundancia no Brasil (Euforbiácea).

Qualquer destes é muito bom, estando puro.

Nos droguistas, aparecem outras espécies de sangue de drago, porém todas falsificadas.

Deve-se escolher, para os vernizes finos de álcool ou de essência, o que for em lágrimas ou então em massa, não estando adulterado nem cheio de impuridades.

\subsubsection{Curcuma, terra merita, vulgarmente chamada gengibre amarela.}

É a curcuma longa de Lineu, à qual os franceses dão os diversos nomes: Souchet des Indes, curcuma, terremerite, e safran des Indes. Há duas qualidades: curcuma longa, e curcuma rotunda.

Pertence esta planta à família dos gingiberaceos ou amomaceos, e vem de Coromandel, e do Malabar. Cultiva-se no Brasil, sob o nome de açafrão.

A raiz, que é a parte da planta do que só se faz uso, tem uma inteira semelhança com a raiz da nossa junça; é só um pouco mais nutrida.

Os droguistas a vendem reduzida a pó: deve-se escolher a mais subida em cor amarela-alaranjada.

Serve esta substância para dar aos vernizes mutativos, chamados douraduras, uma bela tinta de amarelo dourado sobre os metais brancos e latões.

\subsubsection{3. Álcool, Álcool, ou Alkool.}

É palavra árabe, que significa o sutilíssimo, e que hoje somente se dá ao 
espírito de vinho retificado até estar em puro álcool.

É um espírito muito inflamável, menos pesado do que a água destilada, de sabor acre e quente, sem cor e de um cheiro picante aromático.

Tira-se do vinho, do açúcar, dos frutos, dos cereais e de todos os corpos vegetais que possuem parte sacarina.

O álcool puro deve marcar 42 a 43 graus no areômetro de Baumé: neste estado é o melhor e o mais pronto dissolvente de todas as substâncias resinosas.

\subsubsection{4. Álcool: modo de o obter bem retificado para diversas opera- ções indicadas neste livro.}

Toma-se potassa bem seca, que se lança sobre espírito de vinho. O álcali unirse-á à água e o espírito de vinho mais puro sobrenadará. Decanta-se e repete-se a operação, até que a potassa que se lançou no espírito de vinho, saia sem umidade.

Deste modo, faz-se muito puro, mas toma alguma cor. É preciso destilá-lo em um alambique e aproveitar só as primeiras três quartas partes, que serão perfeitamente retificadas.

\subsubsection{Modo de retificar o álcool.}

Deita-se num pipote 8 libras de carvão e 2 libras de cal virgem. Mexe-se 0 mesmo com aguardente. Passados 8 dias, filtra-se e obtém-se uma aguardente desinfetada e forte, e muito própria para se fazer uso dela.

\subsubsection{Modo de reforçar o álcool sem destilação.}

O álcool puro ou absoluto tem muita afinidade para a água, é por isso difícil e trabalhoso obtê-lo da aguardente. Porém, descobriu-se que o pondo em uma bexiga de boi ou de porco e pendurando-se em lugar quente, deixa sair pelos poros a água unicamente, tornando-se, deste modo, a aguardente mais forte. Baseado neste fenômeno, pode-se, da aguardente, fazer-se um álcool quase absoluto pelo meio seguinte: tomase uma bexiga, de boi ou porco, bem limpa da gordura. Enche-se com vento e deixa-se secar, dando-se-lhe, depois, duas mãos de solução de goma de peixe. Enche-se, depois de seca, com aguardente e pendura-se em lugar quente, ou deita-se sobre areia seca no fogão, de modo que se conserve na temperatura de 40 graus. Passados 4 dias, ter-se-á aguardente elevada de 28 graus a 40, ou mesmo a 42 graus.

\subsubsection{Outro método de destilar o Álcool sem alambique.}

Toma-se um barril sem tampa, no qual se coloca um fundo falso 4 dedos acima do fundo legitimo; tendo feito, de antemão, uma porção de pequenos buracos 
no fundo falso. Cobre-se-o com um pano grosso, sobre o qual se deita uma porção de areia seca na altura de um palmo e, por cima desta, uma cama de carvão de lenha, até quase encher o barril. Nesta ocasião, deita-se no barril a porção de aguardente que se tenciona depurar e apara-se a que sai por uma torneira posta logo abaixo do fundo falso e uma polegada acima do fundo legítimo. Torna-se a deitar esta aguardente no barril, 2 ou três vezes, até sair sem cheiro.

O mesmo barril pode servir para 20 e mais pipotes de aguardente.

\subsubsection{8. Éter sulfúrico.}

É um espírito muito fluido e mais leve e mais volátil do que o álcool, extremamente inflamável, de cheiro agradável e de sabor penetrante sem ser ardente.

A sua ação sobre as resinas não é tão extensa como a do álcool, porém, é o mais poderoso dissolvente da goma copal.

O éter nem sempre se acha em estado de vencer esta solução, assim como também a do caout-chouc; e para se lhe conhecer a força, é melhor fazer alguns pequenos ensaios sobre diminutas quantidades destas matérias.

\subsubsection{Terebintina.}

É substância particular entre as resinas e os bálsamos: a sua consistência é bem semelhante a do mel delgado, e a sua cor citrina, às vezes um pouco esverdeada, porém, sempre mui diáfana; o seu cheiro é forte, aproximando-se ao do funcho, e o seu sabor, quente e picante.

É matéria muito inflamável e inteiramente composta de óleo essencial volátil, base do seu aroma e sabor.

É solúvel no álcool, nos óleos essenciais e, também, nos óleos fixos.

As terebintinas superiores em qualidade são as de Chio, superiores mesmo às chamadas de Veneza e de Briançon, que muitas vezes excedem às outras em qualidade; são tiradas da pistacia terebenthus.

As demais terebintinas são as outras que nos vem da França: a de Bordeos supõe-se feita artificialmente com a resina amarela do pinheiro e com a essência de terebintina: é granizada, grossa, muito amarela, sem transparência, com sabor amargo e com o cheiro de resina amarela.

A terebintina de Strasburgo é tirada por incisões feitas nos troncos do larix communis: é também muito ordinária e suja; e não serve para a preparação dos vernizes, que exigem as mais claras e superiores terebintinas, e que devem procurar-se entre as qualidades que já apontamos. 


\subsubsection{0. Óleo etéreo de terebintina, ou essência de terebintina (também se denomina essência, simplesmente).}

É óleo volátil e mui fluido, de cheiro forte, muito inflamável, com a cor mui clara ou, às vezes, citrina.

Obtém-se da terebintina, por destilação.

Esta essência sofre falsificações: a que vem de Espanha é quase sempre adulterada com aguardentes e, algumas vezes, com o óleo de ber, ou de behen.

Conhecem-se estas fraudes deitando-se em um vidro que contenha água simples uma pequena porção de essência, e depois de bem vascolejado, deixando-se o vidro em repouso; se a essência é pura, ajunta-se toda em pequenos glóbulos na superfície da água, que deve ficar clara como antes; e no caso de ficar turva, é porque a essência contém em si aguardente.

Se molharmos uma tira de papel na essência e a evaporarmos a mui brando calor, ou ao sol, e o papel depois ficar limpo e receber a escrita que nele se fizer, é uma prova certa do estado puro da essência; mas se o papel ficar mais ou menos oleado e não receber escrita, é também prova segura de que há óleo fixo misturado; e então a essência não pode servir para vernizes, porque os perde.

\subsubsection{1. Óleo de nozes e de linhaça.}

São estes óleos tão conhecidos que é escusado descrever os caracteres físicos de cada um, nem as suas nomenclaturas; todavia, diremos que, para os vernizes e pinturas de painéis, não há que fiar nestas duas drogas, porque o óleo de nozes é sempre falsificado; e o de linhaça do comércio já não é como o que algum dia vinha da Holanda; hoje é feito de quantas sementes o podem produzir, e ainda de mais a mais corado, grosso e queimado.

O melhor meio de obtê-los puros para estes fins é mandá-los extrair nas fábricas de óleo de amêndoas.

\subsubsection{Dos vernizes de álcool e de essências.}

O álcool é o verdadeiro e o mais enérgico dissolvente das resinas e das gomas resinosas.

Estas soluções dão, em resultado, líquidos que chamamos vernizes, pelo seu brilho depois de aplicados sobre os corpos e depois de estarem perfeitamente secos.

Alguns vernizes de álcool são perfeitamente brancos e muito secantes; porém, roçando-se bem com outros corpos, riscam-se facilmente e se destroem, se a terebintina não entrar em suas composições para Ihes dar mais resistência e aumentar ainda o seu brilho. 
Passaremos em seguida a apresentar as diversas combinações dos vernizes os mais usados nos diferentes países, e cujas bases são as gomas e as resinas, do que já apresentamos a nomenclatura.

\subsubsection{Verniz de copal por meio da cânfora e do óleo essencial de lavândula, destinado aos objetos elásticos, tais como as telas metálicas que substituem as vidraças nas janelas e nas portas dos navios, etc.}

Tomam-se de copal em pó, duas onças; de óleo essencial de lavândula, 6 onças; de alcanfor, uma oitava; e de essência de terebintina, suficiente quantidade, segundo a consistência que se quiser dar ao verniz.

Deita-se em um matraz de vidro o óleo essencial de lavândula e o alcanfor; expõese a mistura sobre banha de areia, e aquece-se até que o líquido ferva lentamente.

Depois ajunta-se-Ihe a copal em pó fino, e por pequenas porções por cada vez, renovando-as logo que cada uma desaparecer no líquido; e favorece-se a solução por meio de uma vareta de vidro ou de madeira branca, para entreter sempre toda a matéria em movimento de rotação.

Encorpada a copal com o óleo essencial, ajunta-se-lhe a essência de terebintina fervendo, não deitando logo toda a quantidade que se pede, mas sim pouco a pouco, até misturar toda a porção, de sorte que o verniz vá sempre conservando uma homogeneidade clara e límpida.

Este verniz é pouco corado, e o repouso de alguns dias depois de feito lhe dá uma transparência que coincide perfeitamente com a solidez de todos os vernizes de copal, o que o torna apto a ser aplicado com acerto em muitos casos, sobretudo na mais moderna e engenhosa substituição do vidro pelas telas de fino arame de latão com que se guarnecem modernamente as janelas dos navios, como oferecendo toda a resistência às percussões do ar durante as descargas de artilharia.

Pode ser tingido este verniz nas cores que se quiserem, porém servindo para esta qualidade de janelas, que vedam o sol e a chuva sem vedar o ar e a luz, propriedade que lhes provém do tecido raro do fio metálico, a melhor cor que se lhe deve aplicar é o verde-mar claro, porque não ofende a vista com os reflexos na luz solar e fica representando as vidraças ao natural; além de que, é de uma duração de muitos anos.

\subsubsection{Verniz de copal pelo éter.}

Toma-se de copal alambreada, meia onça; e de éter puro, duas onças.

Reduz-se a copal a pó muito fino; introduz-se, em pequenas porções, no vidro 
que contém o éter, e tampa-se com rolha de vidro ou de cortiça: agita-se a mistura por meia hora e deixa-se em repouso por 24 horas.

No caso de que, sacudindo o frasco, cubram-se de pequenas ondas as paredes internas, ou que o líquido não fique claro, a solução não está completa, e então se lhe ajunta um pouco de éter na porção de oitava e meia, e deixa-se ainda em repouso até que tenha tomado uma cor citrina clara.

Este verniz forma sobre os metais e sobre as madeiras uma tal capa, que resiste aos choques, os mais violentos, sem se fender, e às roçaduras, as mais ásperas, sem se riscar.

Aplica-se este verniz a pincel, mas como o éter se dissipa prontamente, sobretudo na temperatura quente, passa-se sobre os corpos nos quais se deve aplicar, uma pequena camada de um óleo volátil, quer seja o de lavândula, quer o de terebintina, que se tira em parte, passando-lhe por cima um pano mui brando: a parte oleosa que fica pegada basta para retardar a evaporação do éter.

A copal dissolve-se também na essência de terebintina, e forma vernizes que possuem as mesmas qualidades do precedente; porém, como a essência que se acha no comércio nem sempre goza desta virtude dissolvente, convém retificá-la por uma destilação, e expô-la depois aos raios do sol, durante um mês, e mais tempo em garrafas tampadas de cortiça, deixando-Ihes o gargalo vazio.

Depois desta preparação, fica a essência própria para se prepararem vernizes que rivalizam com o antecedente.

\subsubsection{Verniz de copal feito com essência.}

Toma-se de copal alambreada reduzida a pó, uma onça; e de essência de terebintina como fica recomendado, 8 onças.

Expõe-se a essência a banho-maria, em vasilha de gargalo curto e largo; e logo que a água do banho ferve, deita-se na essência uma pequena porção de copal em pó fino, entretendo-se a vasilha em movimento circular.

Estando a resina incorporada à essência, ajuntam se novas doses de resina, continuando assim até se perceber que no fundo da vasilha se forma um deposito insolúvel; tira-se então o vaso do banho e deixa-se em repouso por alguns dias; côa-se, por fim, o verniz, filtrando-o por algodão cardado.

O verniz que se obtém por este método é mui sólido e brilhante.

Resiste ao choque dos corpos duros melhor do que os esmaltes, que se riscam e perdem o lustre com a impressão de repetidas fricções de corpos estranhos. 
Pule-se muito bem, da mesma maneira que se costumam polir os vernizes de óleo chamados de charão; e aplica-se com o melhor resultado sobre chapas e vasos de metal, e sobre madeiras e outras matérias.

\subsubsection{Verniz para utensílios metálicos e para o ferro.}

Essência de alfazema 2 onças e meia

Essência de terebintina $\quad 1 / 2 \quad$ libra

Cânfora 2 onças

Este verniz aplica-se como todos os outros.

\subsubsection{Dos Vernizes gordos, graxos, ou de charão.}

Os vernizes gordos, ou graxos, são compostos de dissoluções de resinas nos óleos fixos secantes.

Estes vernizes são os mais sólidos e os mais difíceis de secar, ainda que para esse fim se lhes ajunte a essência de terebintina.

Destinam-se aos objetos que são sujeitos a encontros e roçaduras de corpos duros; são particularmente próprios para a decoração dos coches de luxo, e aplicam-se sobre madeira, ferro, latão e cobre e sobre todos os utensílios destes gêneros destinados para usos habituais.

Os processos necessários para preparar estes vernizes, não se limitam a simples infusões.

A natureza seca e sólida das substâncias que lhes devem servir de base, pede outros meios e uma temperatura muito mais elevada.

Ainda que estas substâncias tenham propriedades que lhes são comuns, todavia têm também outras que não dividem; e são estes conhecimentos os que devem levar o artista a não as confundir, e a não as aplicar coletivamente na confecção dos seus vernizes.

Com efeito, a copal resiste muito menos à liquefação em uma temperatura dada, do que o alambre; a goma-resina copal é menos susceptível de decomposição; e o verniz, que resulta da sua mistura com um dos óleos fixos preparados, é menos corado e menos escuro do que aquele que se obtém pela mistura do alambre com o mesmo óleo.

Se a copal se misturasse com o alambre na mesma operação, seria perder o verniz antes que o mesmo alambre se liquefizesse: conhecem-se, portanto, dois vernizes gordos ou graxos: um de copal e outro de alambre. 


\subsubsection{Dos vernizes graxos de óleo e copal, ou de alambre.}

Tomam-se de copal escolhida e bem clara, 16 onças; de óleo preparado de linhaça ou de nozes, 8 onças; e de essência de terebintina, 16 onças.

Faz-se a copal em pó grosso e liquefaz-se sobre fogareiro com brasas, que não façam chama nem fumo.

Esta liquefação deve ser feita em panela de barro vidrado; e ajunta-se, depois da goma resina copal estar derretida, o óleo bem quente, quase em estado de fervura, mexendo-se bem a matéria com uma espátula de ferro.

Tira-se então a panela do fogo; e quando o líquido tiver perdido o maior calor, ajunta-se a essência quente, mexe-se tudo bem, e passa-se por um pano, para uma tigela, guardando-se depois de frio em garrafas de boca larga.

É bom verniz, mui sólido e lustroso; pule-se com pedra-pomes reduzida a pó finíssimo, e por fim, com o trípole, ou pedra-podre.

O tempo contribui muito para a depuração e boas qualidades deste verniz, e quando se faz espesso, dilui-se com quanto baste de essência quente.

\subsubsection{Verniz de óleo secante, ou graxo, ou seja com a copal, ou com o alambre.}

De copal ou alambre em pó preparados segundo o método de Tingry, 4 onças; de essência de terebintina, 10 onças; e de óleo secante, 10 onças.

Mete-se tudo em um matraz posto em banho de areia, e acabada que seja a solução, ajunta-se ao líquido mais um pouco de copal ou de alambre, para saturar bem o verniz; lança-se depois sobre um filtro de algodão, e deixa-se clarificar pelo repouso; e se acontecer ficar o verniz mui grosso, dilui-se com uma pouca de essência quente, para evitar a separação da resina ou do alambre.

Estes vernizes são infinitamente menos corados do que os compostos pelos métodos ordinários, e estendidos sobre metais ou madeiras, dão-lhes um brilho mui sólido.

Quando se queiram encorpar estes vernizes com mais copal, ou sendo de alambre, com maior porção desta matéria, é preciso compor o líquido dissolvente com duas partes de essência sobre uma de óleo.

\subsubsection{Verniz inglês para douraduras, feito pelo óleo graxo secante e 0 alambre.}

De alambre preparado segundo o método de Tingry, 8 onças; de resina laca em grão duas onças; de óleo secante, 8 onças; e de essência de terebintina retificada, 16 onças. 
Derrete-se separadamente a resina-laca, ajunta-se-lhe depois o alambre preparado, o óleo secante de linhaça e a essência, quentes; e logo que esta composição tem perdido parte do seu calor, misturam-se em proporções relativas as tinturas de archiote, de terra merita, de goma resina guta, e de sangue de drago, para se obter uma boa cor de ouro quando se aplica sobre os metais brancos.

\subsubsection{Verniz de alambre.}

Derrete-se sobre brasas uma libra de alambre, ajuntando-se, quando estiver derretido, uma onça de óleo de linhaça quente, mexe-se bem e tira-se do fogo ajuntando aos poucos e mexendo sempre, libra e meia de essência de terebintina.

Este verniz hoje muito usado nos Estados Unidos daAmérica do Norte para envernizar mobílias, carrinhos, etc., por ser muito lustroso, é igual ao melhor verniz da China.

\subsubsection{Verniz de alambre com álcool}

Deita-se num vidro duas onças de alambre e 4 onças de éter, e tampa-se 0 mesmo amarrando sobre a boca um pedaço de uma bexiga molhada; quando, passados 20 ou 30 dias, o alambre se tiver dissolvido, tira-se a bexiga e deixa-se o éter evaporar até ficar uma massa da consistência de xarope, e ajunte-se uma garrafa de álcool; vascoleja-se o vidro até a perfeita solução e guarda-se em vidros bem arrolhados.

\subsubsection{Verniz de caout-chouc para os tafetás encerados, algálias, aeróstatos, etc.}

De caout-chouc ou resina elástica, de óleo de linhaça secante e de essência de terebintina, de cada coisa 16 onças.

Corta-se o caout-chouc em delgadas tiras e deita-se em um matraz posto em banho de areia bem quente.

Logo que a matéria está líquida, ajunta-se o óleo a ferver e, depois, a essência quente; e quando o verniz tiver perdido grande parte do seu calor, passa-se por um pano e guarda-se em garrafas de boca larga.

Este verniz é mui lento em secar, defeito devido à natureza particular do caout-chouc.

\subsubsection{Verniz que imita escama.}

$\begin{array}{lll}\text { Óleo gordo } & 3 & \text { libras. } \\ \text { Copal } & 1 & \text { libra e meia } \\ \text { Essência de terebintina } & 1 & \text { libra e meia. } \\ \text { Terebintina fina } & 1 & \text { libra e meia. }\end{array}$


Este verniz custa a secar; pule-se com pedra-pomes.

\subsubsection{Verniz para tornar impermeáveis os panos e estofos.}

Toma-se óleo volátil, extraído da destilação do alcatrão, que se obtém quando se carboniza carvão de terra; dissolve-se neste óleo, goma elástica ou caout-chouc em bocados.

Feita a dissolução, guarda-se o verniz, que se aplica muitas vezes com um pincel sobre uma das faces do pano.

Põe-se depois sobre este pano, assim envernizado, outro, que se passa entre dois cilindros.

Os panos, juntando-se, formam, por meio do verniz, um pano duplo impermeável à água.

Este verniz pode ser empregado na confecção dos chapéus impermeáveis.

\subsubsection{Tinta para conservar a madeira e o ferro.}

Derretam-se em uma caldeira, doze onças de resina; e estando derretida, deitem-se-lhes 10 libras de óleo de linhaça e três pedaços de enxofre.

Quando tudo estiver caldeado com igualdade, junta-se-lhe o ocre, ou boloarmênio, conforme a cor que se desejar.

Usa-se desta tinta o mais quente possível, e passados alguns dias, estando seca a primeira demão, dá-se uma segunda.

As madeiras expostas ao tempo conservam-se por espaço de muitos anos, sendo pintadas por este método.

\subsubsection{Método para preparar a estearina, segundo Chevreul.}

Chevreul foi o primeiro que anunciou que todas as gorduras animais contêm, em diferentes proporções e segundo a sua natureza, duas substâncias das quais uma é oleiana ou oleína, constantemente fluida e em que reside a parte corante de alguns sebos tais como o de boi, vaca; e a outra é a estearina, que constitui a parte sólida.

Anunciou, outrossim, este autor que a maior ou menor fluidez das diversas substâncias gordurosas é sempre devida à proporção, mais ou menos abundante, da oleína que elas contêm comparativamente a quantidade da estearina, que também possuem; e o método que dá para obter esta, mais facilmente, é o seguinte: funde-se brandamente a fogo lento, a quantidade de sebo de boi que quiserem, e estando bem derretido, côa-se, e deixa-se esfriar: depois limpa-se das impuridades, que sempre se depositam mais ou menos, e torna-se a derreter, deitando-lhe uma 
pequena quantidade de espírito de terebintina bem claro, e o mais fluido que se possa achar no comércio.

Chevreul não indica a quantidade; Braconnot porém, determina meia onça para cada libra do sebo, e diz que esta quantidade de essência ou espírito de terebintina se deve aumentar gradualmente até 2 onças por libra, à medida que as consistências das matérias que se aplicam para tirar a estearina são mais fluidas: por exemplo, descendo da substância mais sólida destas matérias, que é sebo, segue-se o unto de porco, as manteigas, e toda a quantidade de enxúndias, as quais se devem ajuntar 6 oitavas, por cada libra e, às vezes, é preciso 1 onça; e nas substâncias ainda mais fluidas, como é o óleo tirado dos tutanos dos ossos e de outras medulas, se deve ajuntar, por libra, onça e meia até 2 onças de essência.

Derretido o sebo e feita a mistura do espírito, mexe-se a matéria continuadas vezes, por espaço de meia hora, e depois tira-se a caldeira da fornalha, e deixa-se repousar até esfriar de todo.

Toma-se então o pão de sebo, e limpa-se bem de algumas impuridades que se tenham depositado na superfície inferior da mesma massa; e corta-se em porções de forma de talhadas, da grossura de 3 polegadas, as quais se envolvem em papel cartucho, separadamente, para se submeterem a uma pressão forte.

Esta operação mecânica, executa-se entre dois planos de pedra ou de madeira, carregando a prancha superior bastante peso.

É este o meio mais eficaz para prontamente separar a substância fluida (oleína) da substância sólida (estearina).

Cumpre ao fabricante econômico, ajuntar a parte fluida ou oleosa, porque com ela se fabricam os mais excelentes sabões.

Nesta operação os sebos produzem, por cada 8 libras de matéria, 2 ou 3 libras de oleína ou substância fluida, além da porção que os papéis embebem.

Todas as vezes que estes mesmos papéis que envolvem a massa estão impregnados de óleo, mudam-se, e isto deve-se repetir até que os últimos não mostrem mancha alguma oleosa.

Resta então uma matéria muito dura, quase sem cheiro de sebo, e pouco untuosa ao tacto.

Expõe-se ao ar livre, retirada do sol, e de noite ao rocio, para ainda se embranquecer mais e perder de todo o resto do cheiro.

Este método é o mesmo que Braconnot sempre seguiu, com mui pequenas alterações, como logo diremos. 
Se a estearina for preparada com partes iguais de sebo de boi e de carneiro, fica muito mais excelente àquela que se tira do sebo de boi somente; e se for extraída puramente de sebo de carneiro e de bode, então excede em tudo a melhor cera; com a diferença que não é tão dúctil.

\subsubsection{Método para preparar a estearina (segundo Heard).}

Heard foi o primeiro que em Inglaterra pôs em prática as experiências de Chevreul para obter a estearina, e depois de mui repetidos ensaios, achou que as teorias de Chevreul a este respeito são sólidas e as únicas conhecidas para servirem de base à prática química sobre a preparação da matéria.

Todas as substâncias sebosas e gorduras animais, diz este químico, são compostas de dois elementos, por natureza, em perfeita combinação; o primeiro é a estearina, que constitui a parte sólida; o segundo, que é a oleiana ou oleína, forma a parte fluida.

Todas as matérias animais desta natureza, considerando fisicamente, oferecem dois extremos; o primeiro é a substância mais sólida, a que chamamos sebo, e o segundo aquelas substâncias inteiramente líquidas, a que chamamos óleos gordos animais: vê-se logo que a estearina existe em grande quantidade nestas substâncias sólidas, enquanto que nas mesmas naturalmente líquidas, apenas se poderá obter uma amostra dela.

O meio mais fácil e pronto para separar a estearina da oleína consiste em uma forte pressão executada em uma prensa, ou então efetuada do modo que já explicamos no método precedente.

Esta operação mecânica é indispensável para abreviar a extração da matéria líquida e obter a sólida em estado necessário.

As preparações preliminares, reduzem-se a derreter em fogo brando o sebo em rama, quanto mais recente melhor e cortado em miúdas parcelas, ajuntando-lhe quanto baste de água para não se queimar no fundo da caldeira.

Côa-se depois de estar inteiramente derretida e deixa-se esfriar.

Limpa-se então das impuridades, e torna-se a fundir brandamente, e depois que está quase fluido, ajunta-se-Ihe meia oitava de ácido nítrico puro para cada 2 libras de sebo; aumenta-se o calor, e mexe-se a matéria continuadas vezes com espátula de pau, até que a substância tenha tomado uma cor amarela um pouco alaranjada; tira-se então do fogo, e deixa-se esfriar em quietação.

Toma-se depois o pão de sebo, que se corta, embrulha-se em papel pardo cartucho, e submete-se a pressão, seguindo em tudo o mais o que fica dito no método de Chevreul. 
Heard afirma que, de todos os ácidos minerais de que se serviu, o que melhores resultados constantemente lhe deu foi o ácido nítrico bem puro e bem concentrado.

A quantidade deste ácido deve aumentar gradualmente, segundo a consistência mais ou menos branda das matérias, até onça e meia para cada 2 libras de substância, entendendo a última dose para as mais fluidas.

A cor amarela com que a estearina fica, sendo assim preparada, é mui fácil de tirar expondo a matéria a todo o ar livre, sem Ihe dar o sol, e ao rocio da noite, até ficar branca: formam-se depois as velas, e brunem-se quando não saem dos moldes bem lisas e lustrosas.

Como o sebo não existe em estado absolutamente puro e sólido na natureza animal, o mais que se possa procurar para compor as velas contém ainda certa quantidade de óleo.

Braconnot insta que se priva muito facilmente o sebo da oleína, fazendo-se fundir e ajuntando-lhe a quantidade dita de essência de terebintina destilada de novo; e logo que a mistura estiver fria, submetendo-se embrulhada em papel pardo a imprensa ou a pressão semelhante, como já dissemos.

Diz ele que obteve sempre a melhor estearina por este simples método.

Não se trata depois senão de ter o sebo esteárico em fusão, por tempo de uma hora, ou de hora e meia, a calor brando; e deixá-lo depois esfriar e proceder em tudo o mais como nas outras fórmulas.

Em todos os processos que temos dado para obter as melhores estearinas, parece que o método que Heard nos propõe, apesar de ser um resultado prático das suas teorias experimentais, deve ser alguma cousa longo no que diz respeito a fazer perder a cor amarela, com que a estearina fica, quando é obtida por este modo; cor que é devida à oxigenação do sebo pelos ácidos, e que todas as substâncias análogas, uma vez que se oxidam, nunca se perdem sendo somente expostas ao ar livre; porém, o autor é de nome e, pode ser que o que assevera, tenha muito bom êxito nos países frios: o certo é que nas estearinas preparadas com a essência de terebintina, não há receio algum nem grandes delongas para a obter bem branca.

Em todas as artes as teorias devem marchar de mãos dadas com a experiência; e por isso o prático ensaia as suas operações em pequenas quantidades de matérias, não só para obter o meio mais fácil de as compor e aperfeiçoar, mas para também ver qual é o método que lhe fica mais econômico.

A estearina feita só de sebo de carneiro fica um corpo análogo em tudo à cera, porém mais compacto, e por isso mesmo menos dúctil; encera os corpos e os faz luzentes, como a cera dando o mesmo rangido que se ouve quando com esta substância se esfrega; as velas desta estearina são primorosas. 
O sebo de boi é mais amarelo que o de vaca enquanto não está purificado, o que tem feito presumir a muitos que esta cor reside na substância oleosa (oleína): ambos têm um aspecto mais gorduroso do que o de carneiro e o de bode, porque estes contêm menos óleo e mais substância sólida: é esta a razão porque, fundindo-se estes a 49 graus de Reaumur, os de boi, e de vacas se fundem a 46 graus.

As estearinas tiradas destes sebos, com parte igual de sebo de carneiro, são mui excelentes; e mesmo as que são fabricadas com o sebo de boi somente, também são boas e são as mais usuais.

Segundo Braconnot adverte que para fazer as velas de superior qualidade não é preciso extrair inteiramente toda a oleína, a fim de se procurar um sebo em o máximo da sua pureza basta, talvez, extrair 5 por 100, isto é, 5 partes de oleína de cada 100 partes de sebo; e quando se queira uma estearina em toda a sua perfeição, o sebo deve perder 10 partes de oleína por cada 100 partes de seu peso: a experiência assim o ensina.

As velas fabricadas de boa estearina não têm cheiro e dão melhor luz do que a cera, porque não é preciso atiçá-las; e se os pavios são bem feitos, não produzem fumo algum e duram mais do que as de cera.

É preciso recordarmos que a água de cal, em que muitos operam para a depuração dos sebos, é sempre nociva e sem efeito algum útil; além de que dá-lhes mau cheiro.

É também preciso notar que os sebos e todas as substâncias desta natureza, sendo velhos, não dão boas velas, nem das comuns ordinárias, nem tão pouco estearina em circunstâncias de as fabricar.

\subsubsection{Meio de fazer cola.}

Põem-se pedaços de chifre, unhas, cascos, couros numa pipa coberta de água; passadas 48 horas, põe-se tudo sobre o fogo fervendo até à solução de todas estas matérias, ajuntando água de vez em quando; depois côa-se, e engrossa-se até que uma pequena prova, tirada e posta num prato, tenha a consistência de uma geléia dura; tira-se do fogo e despeja-se para um tabuleiro; depois de frio corta-se em fatias, as quais se acabam de secar sobre redes de barbante ou peneiras.

\subsubsection{Meio de fazer cola de ossos.}

Enche-se, com pedaços de ossos lavados, um canudo de ferro ou cobre, ou mesmo de madeira de 3 a 4 braças de altura, 4 palmos de circunferência interior, fechado em baixo por uma torneira; depois tapando em cima hermeticamente, e introduzindo nesta tampa um canudo de cobre, que comunique com um alambique 
no qual se ferve água; os vapores deste entram pelo canudo no cano dos ossos e, abrindo a torneira debaixo, escorre por ela um líquido já de consistência de mel, o qual se leva ao fogo para lhe dar a consistência necessária da cola, e parando de introduzir os vapores de água no canudo, quando o líquido que sai da torneira principia a ficar aguado, é sinal que os ossos estão exaustos.

Os ossos são formados de fosfato de cal e cartilagem pela qual estão ligados: pelos vapores dissolve-se esta, que fornece a cola; é uma cola excelente, quase sem cor, podendo-se aproveitar o resíduo para fazer fósforos.

\subsubsection{Massa para fazer fósforos franceses.}

Clorato de potassa, 3 onças; fósforo, duas onças; goma arábica, duas onças; goma alcatira, meia oitava; água, duas onças e meia; azul da Prússia, uma oitava.

\subsubsection{Lamparina química que dá claridade suficiente para consultar de noite um relógio.}

Tome-se uma garrafa de vidro branco e de forma oblonga, lance-se-lhe dentro um bocado de fósforo do tamanho duma ervilha e, sobre ele, deite-se azeite até a altura de um terço da garrafa, e feche-se hermeticamente; quando se quer empregar, destampa-se a garrafa para deixar passar o ar exterior, e torna-se a tampar.

Então o espaço vazio da garrafa aparece luminoso, e a sua claridade é igual a de uma lamparina.

Se a luz enfraquece, dá-se-lhe forças tirando a rolha e deixando entrar o ar; no inverno é preciso aquecer a garrafa antes de destampar.

Assim preparada, pode servir durante um ano.

\subsubsection{Meio de fazer durar o azeite nos lampiões.}

Dissolve-se num copo cheio de água, o sal que este puder conter; molhe-se nesta solução as mechas, secando-as depois ao sol.

\subsubsection{Papel incombustível.}

Faça-se uma solução concentrada de pedra-ume e água, e mergulhem-se as folhas de papel nesta solução, deixando o papel secar.

\subsubsection{Roupa impermeável.}

Existem vários processos para tornar a roupa impermeável, porém todos eles prejudicam a saúde de quem usa a dita roupa porque, a preparação que ela sofre, tapa-Ihe completamente os poros, impedindo deste modo a penetração do ar, tão necessário a vida. 
O único meio adotado para obstar a este inconveniente, dando ao mesmo tempo um bom resultado, é mergulhar os vestidos que queremos tornar impermeáveis numa dissolução de acetato de alumina, sal que se prepara por muito baixo preço.

Este método é muito econômico.

A droga que mencionamos não exerce ação alguma prejudicial sobre os tecidos e faz, antes, com que estes pareçam mais brandos e macios.

A água escorre sobre a superfície dos tecidos assim preparados, sem os molhar, e não poderia penetrar através deles senão por meio de uma pressão considerável.

\subsubsection{Meio de tornar a roupa incombustível.}

Para a roupa, principalmente os vestidos das senhoras, não pegarem fogo, basta molhar o pano com uma solução feita de uma oitava de clorato de zinco, em uma garrafa de água; este pano sendo molhado, e depois seco ao sol, carboniza-se sem pegar fogo.

\subsubsection{Lamparina sem chama.}

Toma-se uma garrafinha chata e cheia de espírito de vinho, tampa-se com uma rolha furada, para deixar passar a ponta de um pacho de algodão ao redor do qual se enrosca um fio de platina.

Põe-se o fogo ao pacho, e o fio torna-se logo vermelho, sopra-se então sobre o pacho para conservá-lo incandescente.

Os vapores alcoólicos, que se exalam através da mecha encontrando o fio metálico até ficarem vermelhos, se decompõem e fornecem um calor que conservam o fio na temperatura da incandescência.

Como a platina é inalterável, ele conserva constantemente a propriedade de ficar vermelho enquanto capilaridade da outra permite ao álcool de subir; esta lâmpada serve de lamparina porque, sendo preciso de fogo, obter-se-á imediatamente, encostando a este arame ou lume, isca ou qualquer substância inflamável.

Para apagar a lamparina, devera cobrir-se a cortiça com uma capa que empeça o desenvolvimento alcoólico.

\subsubsection{Processo de vulcanizar o caout-chouc e a guta-percha.}

Sabe-se que o caout-chouc é muito sensível às mudanças de temperatura: 0 calor o destrói, o frio o endurece. Descobriu-se um meio de o tornar insensível a estas diferentes influências, unindo-o ao enxofre.

O processo por conversão consiste em expor o caout-chouc a uma mistura de 
sulfureto de carbono ou de clorureto de enxofre; por este processo o caout-chouc não é penetrado senão na sua superfície; este meio é, portanto, insuficiente quando se tem a operar sobre grandes massas de matéria.

O processo por sulfuração ou carbonização, consiste em mergulhar o caoutchouc em enxofre de fusão em diferentes temperaturas; o caout-chouc absorve o enxofre, colora-se em preto e adquire finalmente a consistência do chifre.

Pode-se proporcionar esta propriedade ao caout-chouc em o amassando com enxofre e expondo o todo a uma temperatura de $70^{\circ} \mathrm{R}$, ou ainda fazendo dissolver o caout-chouc em essência de terebintina previamente saturada de enxofre.

As propriedades do caout-chouc assim preparado são as seguintes:

1․ Conserva sua elasticidade em todas as temperaturas, enquanto que a substância não modificada é dura e rígida a 3 e meio graus Reaumur.

$2^{\circ}$ O caout-chouc vulcanizado é inalterável pelos dissolventes ordinários, tais como o sulfureto de carbono, petróleo, essência de terebintina.

Ele se opõe em alto grau à compressão, como prova uma bala de artilharia que arrebentou depois de ter sido lançada contra uma massa de caout-chouc vulcanizado, que apenas esfolou.

O caout-chouc assim modificado serve para fabricar molas, fazer fechaduras, fazer vasos impermeáveis, v. g. garrafa para conservar o éter, tinteiros. É com uma camada desta substância que se protege os fios metálicos contra a ação corrosiva das águas do mar, serve hoje perfeitamente para o aparelho dos mergulhadores que pescam pérolas; também servem com imensa vantagem nos vagões de caminho de ferro; as molas de caout-chouc nunca se quebram.

Um outro processo de vulcanizar consiste na maneira seguinte:

Põe-se em um vaso de pó de pedra, 40 partes de sulfureto de carbono, uma parte clorureto de enxofre, e nesta mistura põe-se o caout-chouc reduzido a folhas, e se deixa mais ou menos tempo neste líquido, conforme a sua grossura; se as folhas são muito grossas, diminuem-se as partes e deixam-se mais tempo, porque tem-se observado que as fortes dissoluções estragam a superfície do caout-chouc, sem por isso o vulcanizar.

Depois que o caout-chouc foi retirado da mistura, suspende-se num quarto a $21^{\circ}$ $\mathrm{R}$ e, quando o líquido está evaporado, lava-se o caout-chouc em muita água, e faz-se ferver durante uma hora, em uma decoada cáustica preparada da maneira seguinte:

$\begin{array}{lcl}\text { Potassa, ou soda } & 1 & \text { libra } \\ \text { Água } & 20 & \text { libras }\end{array}$


Em seguida põe-se a secar, e está terminada a operação.

Para vulcanizar o caout-chouc sem dissoluções, tomam-se 8 a 10 libras de caout-chouc, uma libra de clorureto de enxofre sólido.

Mistura-se bem em uma máquina, devendo-se de vez em quando experimentar se a elasticidade está convenientemente dissolvida e, chegando ao ponto desejado, tira-se a massa e comprime-se ainda quente em uma fôrma.

O mesmo processo é seguido para a guta-percha, devendo-se empregar menos um pouco de clorureto de enxofre sólido.

\subsubsection{Tornar as fazendas impermeáveis.}

Os Chineses tornam as suas fazendas impermeáveis pela aplicação da composição seguinte:

Cera branca derretida, 1 onça; essência de terebintina, meia garrafa.

Põe-se a fazenda neste banho em frio, e depois estende-se, e deixa-se secar.

Esta preparação não aderindo senão aos fios, e não enchendo os interstícios, mesmo nas fazendas as mais finas, não lhes tira nada da sua beleza, e nem mesmo altera as cores por mais mimosas que sejam.

\subsubsection{Processo para fazer o papel de palha.}

Depois da palha pisada, põe-se de molho, e mistura-se, quer com cal, quer com soda ou potassa cáustica; deixa-se em repouso até que esteja em estado de fazer uma massa pegajosa; lava-se, e pisa-se esta massa quer no pilão, quer no cilindro, e reduz-se em folhas, pelo meio costumado; obter-se-á por este meio, papel pardo.

Se se quiser obter papel mais fino; separar-se-hão os nós e a capa, que ainda servirá para fazer papel pardo comum.

Se se quiser papel branco, será preciso tratar a massa com ácido muriático oxigenado (cloro) até que esteja bem clara, e lavá-la depois com um pouco de ácido sulfúrico misturado com água.

Com este processo pode-se fazer papel com linho, cânhamo, com folhas secas, de caniços, das canas de açúcar, de milho, de cascas de pau, etc., etc.

\subsubsection{Papel de couro.}

Toma-se aparas de couro, que são amassadas em um moinho de fabricar papel, e a fazenda alcançada e convenientemente colocada e apertada na prensa, 
e tem muita força e muita macieza, e serve para a encadernação, cobrir certos móveis, e aceita os vernizes e dourados.

\subsubsection{Papelão duro como pedra.}

Ajunta-se a massa do papelão, gelatina, gesso e argila; e, segundo as proporções que se admitir, obter-se-á um papelão com uma dureza maior ou menor.

\subsubsection{Meio de tornar o calçado impermeável.}

O processo seguinte pode-se aplicar a toda a espécie de calçados, grossos ou finos, quer para mulheres, quer para homens.

Põe-se a derreter numa panela vidrada, posta perto do fogo, uma certa quantidade de alcatrão, acrescentando um pouco de goma elástica cortada em tiras muito finas e amolecidas, anteriormente, acima do vapor de água quente; mexe-se a mistura com uma colher de pau e, quando a goma está perfeitamente dissolvida, se aplica por meio de um pincel uma camada desta mistura ainda quente sobre a primeira sola do calçado, que se põe perto do fogo; unta-se em primeiro lugar a costura, tendo o cuidado que não exceda de um lado e outro; e em seguida unta-se toda a superfície, e repete-se esta operação até que a camada tenha pouco mais ou menos a grossura de 2 cartas de jogar.

Só será necessário deixar secar o calçado.

\subsubsection{Cimento que se assemelha ao Cimento Romano.}

Misturam-se partes de areia e cal já queimada, e meia parte de tijolo bem peneirado; faça-se de tudo, com água, uma massa líquida, e à medida que se vai trabalhando, vai-se lançando meia parte de cal viva em pó, misturando-se bem toda a argamassa.

Esta adição de cal viva absorve subitamente a água supérflua; opera-se de repente uma cristalização confusa de toda a massa, que se acha mais dura ao termo de dois dias do que o betume ordinário em muitos meses.

\subsubsection{Betume submarino.}

Derretem-se 2 onças de goma elástica picada em pedacinhos e ajunta-se-lhe, depois de derretida, uma onça de óleo de linhaça, derretendo-se nesta mistura 2 libras de goma laca; este betume é aplicado nas obras de madeira que são merguIhadas n'água; ajuntando-se a esta massa enquanto quente, 1 libra de alvaiade e meia de pó de tijolos, serve para betumar facas em seus cabos. 


\subsubsection{Betume de pedra.}

Cera branca e breu, partes iguais; derretem-se em um tacho de metal e, estando líquida, mistura-se quanto pó de pedra lioz a cera pode absorver.

Este betume aplica-se quente e deve-se também aquecer as partes que se quer unir com ele.

Serve igualmente para armar e concertar as plantas marinhas petrificadas.

\subsubsection{Betume para segurar grades de ferro sobre pedras.}

Usa-se hoje de enxofre em lugar de chumbo derretido para segurar o ferro sobre pedras, com muito mais vantagem, porque segura melhor.

\subsubsection{Cimento para fixar o metal sobre o vidro ou madeira.}

Este cimento é formado de partes iguais de goma-laca e pedra-pomes em pó fino.

Derrete-se primeiro a goma laca na mais baixa temperatura possível, incorpora-se o pó com ela em fusão.

Este cimento cola muito melhor do que a goma-laca simples, o que tem sido verificado pela experiência.

\subsubsection{Betume para vedar o coamento dos líquidos dos tonéis, barris, ou pipas.}

Duas partes de sebo e uma parte de cera derretida; mistura-se, de cinza peneirada, metade do volume da matéria, mexe-se até esfriar e guarda-se para uso.

\subsubsection{Grude que não endurece.}

Há alguns ofícios que necessitam varias vezes ao dia de um pouco de grude: como é muito incômodo fazer grude a toda hora; e como o grude feito pelo método seguinte conserva-se sempre mole e perfeito, espero que algumas pessoas apreciarão a receita deste grude.

Faça-se um pouco de grude como de costume, e depois de feito, ajuntem-se a cada meia libra de grude, 2 oitavas de pedra-ume de antemão dissolvida em 2 onças d'água quente, e 16 pingos de ácido nítrico; este grude conserva-se perfeito por espaço de 8 a 10 dias sem azedar, sem criar mofo e sem secar.

\subsubsection{Cola forte natural.}

As grossas lesmas que se acham nas hortas e que algumas pessoas comem têm uma vesícula cheia de uma substância gelatinosa de cor alvacenta, que aplicada 
entre dois corpos, tais como pedaços de porcelana, vidro, pedra, os une da maneira a mais sólida, contanto que as partes quebradas estejam postas bem em contato.

Esta substância pode, com vantagem, suprir a cola que está habitualmente em uso, contanto que se lhe dê o tempo de secar bem.

\subsubsection{Cola de goma arábica.}

Faz-se dissolver goma arábica em aguardente com água alcoolizada com um pouco de açúcar derretido; e guarda-se em vidros bem tampados para servir quando for necessária.

\subsubsection{Cola ou grude de arroz.}

Dilui-se em água fria, farinha de arroz, que se faz cozinhar sobre um fogo brando até que congele; esta cola tem uma cor alva e torna-se quase transparente quando seca; sua força é tal, que é mais fácil rasgarem os papéis colados com ela do que os desunirem; por isso emprega-se, de preferência, em obras de papel, encadernação, etc.

\subsubsection{Meio de tornar panelas e potes de barro e de pedras mais resistentes.}

Untam-se as vasilhas com óleo de linhaça, pondo-se ao sol para secar; depois da primeira camada ter secado, tornam-se a untar com o mesmo óleo, repetindo-se esta operação 5 a 6 vezes.

\subsubsection{Modo de tornar o calçado impermeável á água.}

Óleo de cravo, 3 onças; sebo de carneiro, seis oitavas; cera amarela, 4 oitavas; resina, meia oitava.

Derrete-se tudo em vaso de barro, e quando esta preparação está meio fria, estende-se com uma broxa sobre as botas e os sapatos, estando o couro bem seco.

\subsubsection{Nitreiras artificiais.}

As nitreiras artificiais podem considerar-se como meios fáceis de fabricar o salitre ou azotato de potassa, ou para empregar principalmente nas artes.

Consistem em abandonar à decomposição espontânea as matérias animais, expostas ao ar livre e misturadas com cinzas e terras calcárias.

Nos currais ou cavalariças muito arejadas formam-se montões, em forma piramidal, com terras movediças ou estrumes animais e vegetais, cinzas e cal, com ramos ou palhas interpostas, para tornar permeáveis ao ar as mesmas pirâmides; 
as paredes exteriores devem ficar formadas em socalcos; devem ser regados de dias à dias com urina.

Debaixo da influência do ar as matérias animais decompõem-se, fornecendo grandes quantidades de amoníaco, que decompondo-se por seu turno fornece ácido nítrico, e pela presença dos álcalis das mesmas matérias, principalmente a potassa, forma o nitrato de potassa, que se apresenta, no fim de dois ou três anos, à superfície, em flocos como os da neve; este salitre, apesar de muito impuro, raspase e solve-se em água para o separar das matérias térreas que o acompanham, o que se consegue por meio de cristalização; e querendo-lhe separar os cloruretos de sódio e potassa que o acompanham, em maior ou menor escala, emprega-se a chamada refinação que consiste em separar os sais diversos, segundo o seu maior ou menor grau de solubilidade, para o que será conveniente consultar algum tratado de química.

Estas nitreiras podem, nos campos melhor do que nas cavalariças, constituir um sofrível ramo de indústria em atenção as insignificantes despesas.

\subsubsection{Meio de conservar a madeira de construção.}

Dissolvem-se oito libras de sulfato de cobre, e molhe-se cinco a seis vezes com esta solução, por meio duma broxa ou dum pano, a madeira depois de bem seca; ficará esta livre do cupim, do caruncho e, qualquer madeira branca afincada, durará tanto como a melhor madeira de lei.

\subsubsection{Madeira; receita para torná-la incombustível.}

Dissolva-se terra silicosa em álcali cáustico (Potassa cáustica), e estenda-se este líquido sobre a madeira.

Depois pode-se lançá-la no mais ardente braseiro, porque o fogo não terá ação sobre ela.

\subsubsection{Modo de dar rijeza à madeira.}

A madeira que, depois de embebida de qualquer óleo ou matéria gordurenta, se conservar exposta por algum tempo a um calor moderado e depois de esfriar, fica muito luzidia e seca, e tem contraído às vezes tal rijeza, que corta e fura como uma arma de ferro.

Os selvagens servem-se deste meio para endurecer suas armas de pau, na falta do ferro. 


\subsubsection{Meio de dar duração à madeira.}

Uma forte dissolução de sulfato do ferro (caparrosa verde) aplicada bem quente sobre a madeira já trabalhada, a preserva igualmente de apodrecer com a umidade e de ser roída pelos insetos.

As pequenas peças de madeira já trabalhadas, sendo fervidas em dissolução de caparrosa, quase tornam-se eternas.

É, todavia, preciso avisar que estas peças devem estar prontas porque, a madeira assim preparada, embota todas as ferramentas cortantes que se lhe apliquem.

\subsubsection{Meio de empregar a madeira verde sem empenar.}

Depois de descascada e serrada na bitola desejada, expõe-se à madeira durante 10 dias em água de cal.

\subsubsection{Processo para tornar a madeira indestrutível.}

Areia silicosa que se dissolve em uma solução de potassa cáustica; faz-se um líquido bastante grosso com o qual se unta a madeira.

\subsubsection{Meio de fazer cal virgem em pequena porção.}

Mistura-se uma porção de mármore, mariscos ou pedras de cal em pó, com um pouco de azeite ou açúcar, e queima-se num cadinho ou em qualquer outro fogo.

Facilmente se compreende a teoria do que se passa quando se aquece 0 mármore assim preparado, porque o ácido carbônico deste põe-se facilmente em presença do carvão formado do açúcar, e transforma este em óxido de carbono, que não tem afinidade para a cal e se evapora.

\subsubsection{Cimento impermeável á água.}

Apaga-se a cal viva com sangue de boi em vez de água; tomam-se pedaços de telha, que se socam bem e se passam na peneira; mistura-se este pó até a consistência de argamassa, que depois de seca, fica tão dura que são precisas ferramentas de aço temperado para a desmanchar.

Se se quiser cobrir com ela um lugar úmido, é preciso segurá-la alguns dias com tábuas.

\subsubsection{Argamassa para edificar.}

As argamassas para alvenaria devem ser feitas com a cal extinta ao ar e sem água alguma; quanto mais velha ela for, maior tenacidade ela proporcionará à argamassa preparada com ela. 
A cal extinta com água é muito mais fraca e tornam-se fracas as argamassas com ela preparada.

Logo está claro que a qualidade dos materiais depende unicamente do modo de os preparar para se aplicarem.

A água é um dos materiais que merece toda a atenção nas alvenarias dos edifícios; deve ser pura, de fontes ou de ribeiros, e nunca de forma alguma salgada, nem salobra.

Para fazer boa argamassa, as porções são: 3 partes de areia delgada; 4 partes de saibro delgado (areia grossa) e de cal extinta de per si, 4 partes; água pura restritamente só a que for precisa para amassar; a perfeição da argamassa não consiste só em estar amassada, é preciso a enxada estar sempre sobre o material, para lhe procurar uma perfeita combinação.

Nisto se esmeravam muito os antigos.

\subsubsection{Modo de cobrir casas com papelão.}

Funde-se num tacho uma libra de goma elástica (caout-chouc) e, estando derretida, ajuntem-se pouco a pouco, duas arrobas de óleo de linhaça e duas de alcatrão; deixe-se ainda ferver por meio quarto de hora, e ajuntem-se 4 libras de breu dissolvido em 8 libras de aguarrás; nesta mistura mergulham-se, depois de fria, folhas de papelão, por duas vezes, para se embeberem bem do óleo; secando-as depois, pregam-se com tachas pequenas sobre tábuas que deitam-se sobre os caibros; estando assim tudo coberto, dá-se uma mão de óleo, o qual une entre elas as folhas de papelão, e põe-se nova camada de folhas de papelão, porém de maneira que fiquem as juntas destas desencontradas com as juntas da primeira camada; dando finalmente outra mão de óleo, peneirando por cima uma camada de areia.

Este modo de cobrir as casas serve principalmente para casas de telhado baixo, para formar por cima lugar para passear e apreciar as tardes depois dos dias quentes.

\subsubsection{Adobes de taipa.}

Sendo os tijolos caros para a construção, os adobes friáveis e de pouca duração, e a taipa difícil, chegando o muro em certas alturas, explicamos o método de fazer adobes de taipa, como se usam na Rússia.

Faça-se uma fôrma de ferro fundido, embutindo esta dentro de uma de madeira para não quebrar; por outro lado, faça-se uma cunha de pau duro, que entre justamente na fôrma de ferro, e encha só metade da mesma, e enche-se o resto de terra quase seca; leva-se debaixo de um peso, suspenso por uma corda que passa 
sobre uma roldana e segura por dois homens; põe-se a cunha como uma tampa em cima da fôrma, e deixa-se cair o peso, duas ou três vezes, até a cunha ter entrado na fôrma, sendo isto sinal que a terra dentro da fôrma ficou bem ataipada; este adobe de taipa é tão duro que só pode ser quebrado à marreta, e resiste por muitos anos à chuva, exposto ao tempo e descoberto; apresentando mais a vantagem de poderem ser feitos no lugar da edificação.

\subsubsection{Método de conservar os aposentos sem umidade.}

Ponha-se num aposento úmido, certa quantidade de madeira com a casca, e em pouco desaparecerá a umidade, que será absorvida pela casca esponjosa da madeira; deve-se renovar a madeira de tempos em tempos, quando ela já absorveu muita umidade.

\subsubsection{Refrescar os aposentos durante os grandes calores.}

Cobre-se um poço, de maneira que o ar não possa sair; pratica-se na tampa dois buracos redondos, que se fecham por meio de dois grandes funis dos quais um tem a boca para o poço, e a outra para fora; coloca-se na extremidade do funil que tem a bacia para dentro, um comprido canudo que está furado à semelhança de uma flauta, por cujos furos se desprende o ar do poço, que fica tocado para fora por uma porção de água que se lança no poço pela boca do funil que está dirigida para a parte de fora.

O ar fica tão frio que parece estar-se na estação fria.

\subsubsection{Meio de curtir os couros.}

Todas as matérias vegetais que contêm um princípio adstringente são próprias para os curtimentos; porém a casca do sumagre, barbatimão, do angelim, da angico e da aroeira, são os que estão geralmente em uso por conterem mais tanino.

Reduz-se a casca a pó grosso, em moinhos próprios, e neste estado misturase em água nos tanques dos curtumes; feita esta infusão a frio, introduzem-se as peles, depois de terem passado pelas preparações necessárias, advertindo que este primeiro banho não deve ser muito forte, na quantidade da casca.

Deixam-se macerar por algumas semanas, com o cuidado de as mexer e virar freqüentemente; aumenta-se gradualmente a solução do tanino, ajuntando mais porções de casca; depois introduzem-se os couros, que há este tempo tem recebido um meio curtimento em outros tanques (se for preciso), em camadas alternadas de peles e de casca em pó, até encher os mesmos tanques: cobrem-se então com uma camada espessa da mesma casca, e molham-se bem com a solução do primeiro banho. 
Por esta forma os couros são expostos à ação inteira do tanino; e ainda se ajuntam algumas porções adicionais dele à medida que a absorção deste princípio se efetua, até que a operação esteja completa, o que se conhece pela mudança da cor que o couro tem tomado, a qual imita a da noz moscada interiormente: quando o processo não está bem acabado, percebe-se um veio branco na espessura do couro.

Logo que o curtimento das peles está em sua perfeição, tiram-se estas do curtume e deixam-se escorrer; põe-se então cada couro sobre uma peça do pau convexa, e bate-se por igual com um ferro apropriado, para o fazer mais compacto; e muitas vezes, para tornar as peles ainda mais sólidas, passam-se dobradas por cilindros de ferro.

Penduram-se depois em telheiros, cujos lados sejam construídos de forma que $o$ ar circule bem pelas quatro faces; e ali se deixam até estarem bem secas.

A sola, para ficar boa, não pode levar menos tempo do que dez meses até um ano, nos climas frios, e às vezes ainda mais.

Está bem conhecido que o couro não ganha somente no peso por uma longa exposição em contacto com o tanino, mas também na qualidade.

A natureza destes processos tem sido particularmente estudada pelos químicos franceses e ingleses.

\subsubsection{Curtir as peles.}

Para obter-se uma grã muito superior e muito mais fina do que aquela que se obtém pelo processo ordinário.

Tomam-se as peles já curtidas, as que são mais perfeitas e mais grossas para poderem melhor sofrer o novo processo porque elas têm de passar; põem-se dentro da água limpa até ficarem bem embebidas.

Neste estado, toma-se uma que se estende sobre um cavalete, que se cobriu de uma outra pele bem grossa, bem limpa, mas ainda não preparada e, com um facão de grosar, o oficial encosta sobre a pele de carneiro ou de cabrito, do lado da flor, e faz andar com muita força o facão até que tenha tirado a primeira e segunda epiderme que, em termo de surrador, é apelidado primeira e segunda flor.

Quando o oficial tirar esta primeira e segunda flor, põe-se a pele a secar na sombra, pendurando-a em cordas bem limpas; depois de seca a pele, é aberta e manipulada, e estendida numa tábua; depois da pele seca e aberta, é entregue ao oficial polidor, que a estende sobre um rolo de grosador, e passa a pedra-pomes sobre o lado da pele donde foi tirada a primeira e segunda flor. 
Querendo que ela seja branca, para depois ser tinta, o oficial não deverá se servir senão de areia do mar para poli-la; ele esfregará esta por meio da pedrapomes, que ele fará passar sempre de cima para baixo.

Querendo que ela seja de cor amarela clara, que é a que se procura mais, recorrer-se-á uma pedra composta de 6 partes de branco de Meudon (tabatinga) e 2 partes de ocre amarelo; e depois passa-se esta pedra sobre toda a superfície da pele onde estavam a primeira e segunda flor, tendo o cuidado de pôr um pouco de areia.

Finalmente, põem-se as peles e alisam-se com um ferro, como se fossem roupas, o que lhes dá mais brilho e mais macieza.

\subsubsection{Solas impermeáveis.}

Estende-se uma ou duas camadas de óleo de linhaça sobre as duas faces de uma sola de cortiça, quando esta estiver bem seca, põe-se no interior do sapato que também se unta do mesmo óleo de linhaça de maneira a tapar todos os furos feitos pela sovela; põe-se depois uma palmilha sobre a sola de cortiça, e ficar-se-á livre da umidade nos pés.

Nos sertões de Goiás e Mato Grosso, curtem as peles com cabelo ou sem ele, expondo-as à fumaça da lareira durante uns quinze dias, tendo as previamente limpas de todas as gorduras e carnes, e enroladas com o carnaz para fora: raspamse neste estado o pelo, que sairá com facilidade, e põem-se as peles em um coche com soro de leite, onde permanecem durante 15 ou 20 dias, mudando de 3 em 3 dias o soro de leite, e ficam perfeitamente curtidas; se se pretende conservar o pelo, limpam-se unicamente as peles perfeitamente, e põem-se imediatamente no coche de soro, e pratica-se como já foi explicado. 


\section{4 - Considerações Finais}

O trabalho que aqui se encerra é o de divulgação deste grupo específico de receitas. As pesquisas com estas e com as receitas restantes podem avançar em direção a inúmeras áreas de interesse que guardam afinidades com o Ecoturismo, como a gastronomia e a restauração. Um pequeno detalhe em uma receita pode sugerir uma vasta área para pesquisa.

Muito ainda resta a ser feito para que o conteúdo desta monografia se torne efetivamente um instrumento de educação ambiental ou um manual de técnicas de "Vida nos bosques". Seu aprimoramento pode caminhar para o desenvolvimento de ilustrações para as receitas, ou mesmo para a execução dos procedimentos com documentação fotográfica. Para seu uso como ferramenta de educação ambiental, as receitas admitem múltiplos tipos de formatação, como cartilhas ou apresentações em data show, por exemplo.

Outro estudo promissor é a associação dos métodos de Victor Renault aos do Design Passivo. É pertinente recordar que o livro Tesouro das Famílias é composto de 1.952 receitas sobre assuntos que ultrapassam os propósitos desta monografia. Mas abordagens diferentes gerarão diferentes seleções das receitas desta vastíssima obra.

No caso específico deste trabalho, o principal critério para selecionar as 172 receitas foi proporcionar referências da vida simples que o homem do século XIX levava e que podem ser reproduzidas na atualidade. A leitura de tais referências, para alguns, será mero entretenimento, o que, em se realizando, já é motivo de grande satisfação para qualquer autor. Para outros, pode ser fonte utilíssima de informação, pois o empirismo e as pesquisas de Victor Renault são eficientes catalisadores de insights para os estudiosos das áreas em questão.

Como visto nas seções que tratam dos "Criativos Culturais" e dos adeptos da "Simplicidade Voluntária", a clientela do Ecoturismo é identificada como pessoas que apesar de disporem de renda superior, são preocupadas com os altos padrões de consumo do mundo industrializado e direcionam seus gastos para produtos que traduzam benefícios para regiões menos favorecidas. Além disso, são atraídos pela simplicidade e pelo exótico. Portanto, também os empreendedores em Ecoturismo ou atividades afins que atendem ou pretendem atender esta clientela podem encontrar utilidade na leitura deste trabalho.

Porém, o alvo principal desta monografia são pessoas que muitas vezes precisarão que outros Ihes auxiliem em sua leitura. Inúmeros brasileiros que sobrevivem, ainda nos dias atuais, como se vivia no século XIX, absolutamente excluídos do que se convencionou chamar progresso, mas que em muitos casos é apenas o avanço desordenado do mundo industrial sobre as áreas naturais e rurais que habitam. 
Se estas populações esquecidas, dissociadas de suas tradições, que encontram dificuldades diárias para conseguir o seu sustento, tirarem qualquer proveito do conteúdo desta monografia, aí sim, seu principal objetivo terá sido cumprido. Afinal, é exatamente este o ponto de interseção deste trabalho com o Ecoturismo: a busca por soluções mitigadoras da pobreza crônica e involuntária que castiga as populações excluídas. 


\section{Referências Bibliográficas}

ARAÚJO, Alceu Maynard, Cultura Popular Brasileira, São Paulo, Melhoramentos, 1973

BLAKE, Augusto Victorino Alves Sacramento, Diccionario Bibliographico Brazileiro, Sétimo Vol, .Rio de Janeiro, 1902.

BURTON, Richard, Viagem do Rio de Janeiro a Morro Velho, 1868, reprint, Senado Federal, 2001.

ELGIN, Duane, Simplicidade Voluntária, São Paulo, Cultrix, 1993,

EMERSON, Ralph Waldo, Ensaios, Martin Claret, 2003

FRANGETTO, Flávia Witkowski, GAZANI, Flávio Rufino, Viabilização Jurídica do Mecanismo de Desnvolvimento Limpo (MDL) no Brasil, 2002, São Paulo, Peirópolis, 2002, ISBN: 85-85663-96-0

GASTAL, Susana e CASTROGGIOVANI, Antonio Carlos. Turismo na pósmodernidade (des) inquietações. Porto alegre. Edipucrs, 2003. ISBN 85-7430-329-1

Comércio Exterior - Informe BB -, Edição 50 - ano 11 - nov./dez. 2003

KOESTLER, Arthur, Jano, Melhoramentos, 1978

MACCANNELL, Dean (1973) Staged authenticity: arrangements of social space in Tourism Settings. American Journal of Sociology, 79

MANKIW, Gregory, Introdução à Economia, Rio de Janeiro, Campus, 2001, ISBN: 85-352-0853-4

Manual de Ecoturismo de Base Comunitária: ferramentas para um planejamento responsável - WWF - Brasília . 2003. ISBN: 85-86440-12-4

MARAUX, Vincent, Pierre Victor Renault - Um pioneiro Francês no Século $X I X$, Virtual Books, 2000

MARQUES, Maria Inez Medeiros, O Conceito de Espaço Rural em Questão, Terra Livre, São Paulo, Ano 18, oo 19 jul/dez. 2002.

MARTINS, José Clerton de Oliveira (organizador), Turismo, Cultura e Identidade, São Paulo, Rocca, 2003, ISBN: 85-7241-447-9 (pg 49)

MASI, Domenico De, O Ócio Criativo, Rio de Janeiro, GTM, 2000, ISBN: 85-86796-45-X (Pg 57)

PELLEGRINI, Américo; Ecologia, Cultura e Turismo. São Paulo: Papirus, 2000 
RIBEIRO, Darcy, O Povo Brasileiro, São Paulo, Schwarcz, 1995, ISBN: 85-7164-451-9

RIEDL, Mário, ALMEIDA, Joaquim Anécio, VIANA, Andyara Lima Barbosa (organizadores), Turismo Rural: Tendências e Sustentabilidade, Santa Cruz do Sul, EDUNISC, 2002, ISBN: 85-85869-95-X

SILVA, Mauren Fronza da, ALMEIDA, Joaquim Anécio, III Congresso Internacional Sobre Turismo Rural e Desenvolvimento Sustentável, "Turismo Rural, Patrimônio e Cultura", pg. 51, EDUNISC, 2002

THOREAU, Henry David, Walden, A vida nos Bosques, São Paulo, Aquariana, 2001, ISBN: 85-7217-070-7

TULIK, Olga, Turismo Rural, São Paulo, Aleph, 2003

VERBOLE, Alenka, Turismo Rural: Tendências e Sustentabilidade, "A Busca pelo Imaginário Rural", pg. 117, EDUNISC, 2002

WOOD, Megan Epler. Ecotourism: Principles, Pratices \& Policies for Sustainability - UNEP - 2002 - ISBN: 92-807-2064-3

\section{INTERNET}

An Overview of the Voluntary Simplicity Movement - www.stretcher.com/ stories/960415c.htm - 28/6/2004 17:48:57

Associação Brasileira de Turismo Rural - www.abtr.com.br - 15/8/2004

Cultural Creatives - www.culturalcreatives.org/lifestyles.html 6/7/2004 15:02:31

Epler Wood International - http://www.eplerwood.com/bio.php - 22/6/2004

The International Ecotourism Society - www.ecotourism.org 18/5/2004

Unidades de Medida - www.unificado.com.br/fisica/unidades.htm - 16/8/2004 